Los Alamos National Laboratory

Yucca Mountain Project Publications (1979-1994)

Compiled by

L.M. Bowker

M.L. Espinosa

S.H. Klein 


\section{DISCLAMMER}

Portions of this document may be illegible in electronic image products. Images are produced from the best available original document. 


\title{
LOS ALAMOS NATIONAL LABORATORY YUCCA MOUNTAIN PROJECT PUBLICATIONS (1979-1994)
}

\author{
Compiled by
}

L.M. Bowker, M.L. Espinosa, and S.H. Klein

\begin{abstract}
This over-300 title publication list reflects the accomplishments of Los Alamos Yucca Mountain Site Characterization Project researchers, who, since 1979 , have been conducting multidisciplinary research to help determine if Yucca Mountain, Nevada, is a suitable site for a high-level waste repository. The titles can be accessed in two ways: by year, beginning with 1994 and working back to 1979 , and by subject area: mineralogy/petrology/geology, volcanism, radionuclide solubility/groundwater chemistry; radionuclide sorption and transport; modeling/validation/field studies; summary/status reports, and quality assurance.
\end{abstract}




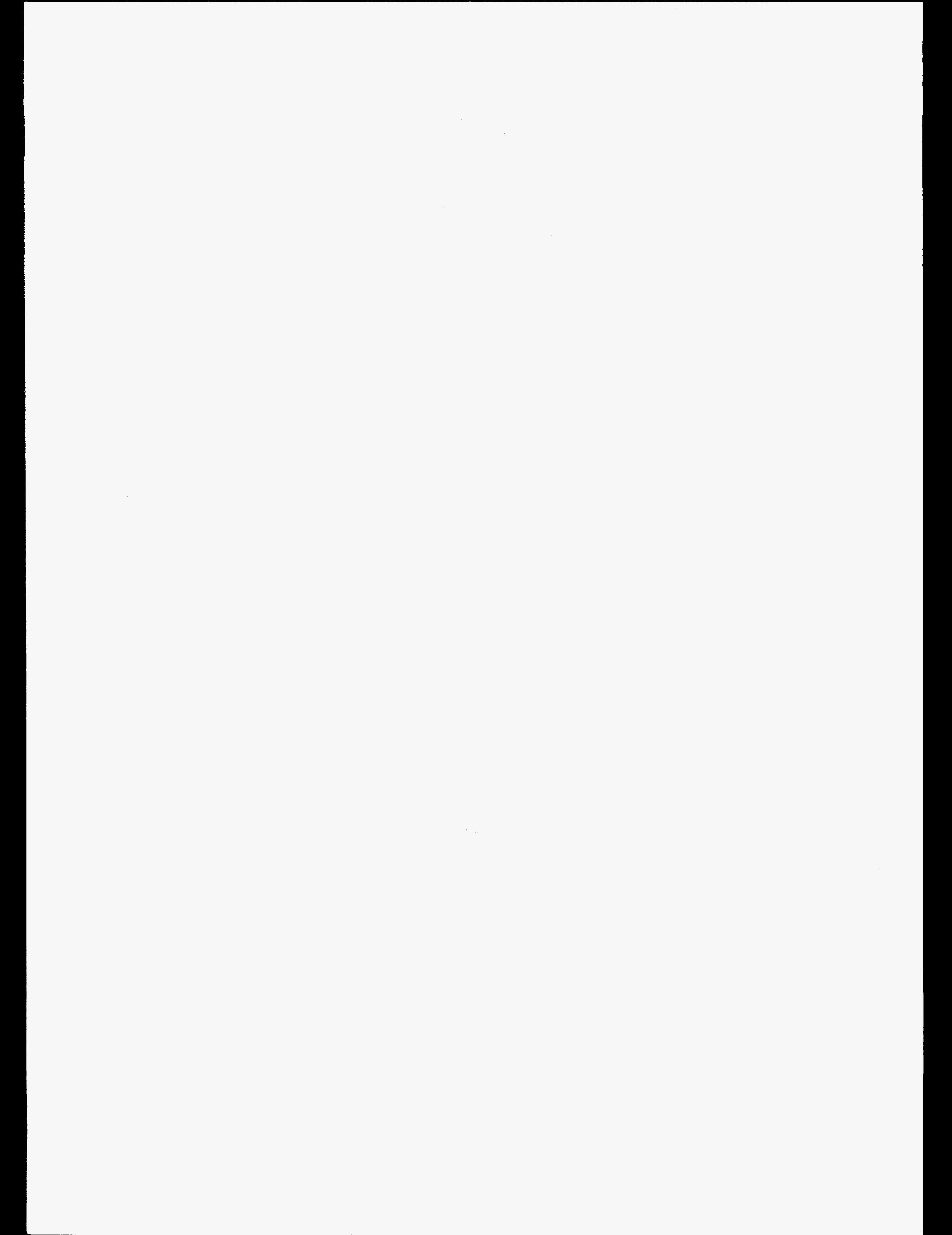




\section{Introduction}

Between 1955 and 1979, scientists studied several options for handling this country's high-level nuclear waste. Proposals to dispose of the waste ranged from burial in the ocean floor to rocketing it into outer space. After extensive evaluation, it was determined that underground disposal would have the least environmental impact, and in 1979 preliminary investigations began at Yucca Mountain, Nevada, as well as several other potential sites. The Nuclear Waste Policy Act (NWPA) of 1982 formalized the process to select a high-level nuclear waste repository site, established the responsibilities for characterization, operation, and oversight, and established the Nuclear Waste Fund. The NWPA amendment of 1987 identified Yucca Mountain as the only site to be considered for characterization.

For over 15 years, Los Alamos researchers have been conducting multidisciplinary research to help characterize Yucca Mountain to determine its suitability as a site for a high-level waste repository. They have been defining the nature and distribution of minerals and other geological features of the Yucca Mountain site and determining the extent to which the natural barriers would prevent and/or retard the release and migration of radionuclides from the potential repository. They have been developing models to understand ground-water chemistry flow paths to the accessible environment and determining mineralogy and petrology along these flow paths. Additionally, they have been determining the complexities of radionuclide solubility limits, radionuclide sorption as a function of mineralogy and ground-water chemistry, radionuclide diffusion in tuff, and radionuclide migration at all scales, as well as studies on microbiological activity as it affects transport. The mineral alteration history of the mountain is also being studied, and there is an extensive effort to assess the probability of future volcanic activity in the region by determining the characteristics of past eruptions, partly through the application of corroborating Quaternary dating methods. Finally, modeling and field validation studies are being conducted. 

1. Birdsell, K.H., K.G. Eggert, and B.J. Travis, "Three Dimensional Simulations of Radionuclide Transport at Yucca Mountain," Radioactive Waste Management and Environmental Restoration 19, 1-28 (1994).

2. Bish, D.L., "Quantitative X-ray Diffraction Analysis of Soils," in Quantitative Methods in Soil Mineralogy, J.E. Amonette and L. W. Zelazny, Eds. (Soil Science Society of America, Madison, Wisconsin, 1994), pp. 267-295.

3. Bolivar, S. L., "Los Alamos National Laboratory Yucca Mountain Site Characterization Project 1992 Quality Program Status Report," Los Alamos National Laboratory report LA-12703-SR (1994).

4. Bolivar, S. L, and J. L. Day, "The Transition to a Revised Quality Assurance Standard, the Los Alamos Experience," Proceedings of the Nineteenth Annual American Society for Quality Control (ASQC) National Energy \& Environmental Quality Division Conference, September 18-21, (1994).

5. Canepa, J. A., I. R. Triay, P. S. Rogers, M. E. Hawley and G. A. Zyvoloski, "The Yucca Mountain Site Characterization Project: Site-Specific Research and Development on the Chemistry and Migration of Actinides," in Chemistry and Migration Behavior of Actinides and Fission Products in the Geosphere: Proceedings of the Fourth International Conference, Charleston, South Carolina, USA, December 12-17, 1993, pp. 813-820 (1994).

6. Carey J. W., and D. L. Bish, "Enthalpy of Hydration of Cation-Exchanged Clinoptilolite," American Geophysical Union 75 (44), 698 (1994).

7. Carlos, B. A., "Field Guide to Fracture-Lining Materials at Yucca Mountain, Nevada," Los Alamos National Laboratory report LA-12803-MS (1994).

8. Clark, D. L. and P. Palmer, "Oxygen-17 and Carbon-13 NMR Studies of Uranyl and Neptunyl Carbonate Complexes in Near-neutral Solution," in Chemistry and Migration Behavior of Actinides and Fission Products in the Geosphere: Proceedings of the Fourth International Conference, Charleston, South Carolina, USA, December 12-17, 1993, p. 32 (1994).

9. Clark, D. L., J. G. Watkin, D. E. Morris, and J. M. Berg, "Molecular Models for Actinide Speciation," Los Alamos National Laboratory report LA-12780-MS (1994).

10. Clark, D. L., S. A. Ekberg, D. E. Morris, P. D. Palmer, C. D. Tait, "Actinide (IV) and Actinide (VI) Carbonate Speciation Studies by PAS and NMR Spectroscopies," Los Alamos National Laboratory report LA-12820-MS (1994).

11. Conca, J. L., and I. R. Triay, "Selenite Transport in Unsaturated Tuff from Yucca Mountain," in High Level Radioactive Waste Management: Proceedings of the Fifth Annual International Conference, Las Vegas, Nevada, May 22-26, 1994 (American Nuclear Society, La Grange Park, Illinois, 1994), pp. 1275-1282. 
12. Day, J. L., P. L. Gillespie, and S. L. Bolivar, "The Quality Council in the Scientific Arena," 48th Annual American Quality Congress (AQC) Proceedings Las Vegas, Nevada, May 24-26, 87-92 (1994).

13. Kalia, H. N., and J. M. Replogle, "Starter Tunnel at Yucca Mountain," in Institute of Shaft Drilling Techniques: Conference Proceedings of the April 13-21 Meeting, (1994).

14. Kung, K. S., and I. R. Triay, "Effect of Natural Organics on Cd and Np Sorption," Radiochimica Acta 66/67, 421-426 (1994).

15. Nitsche, H. N., K. Roberts, T. Prussin, A. Muller, K. Becraft, D. Keeny, S. A. Carpenter, and R C. Gatti, "Measured Solubilities and Speciations from Oversaturation Experiments of Neptunium, Plutonium and Americium in UE-25p \#1 Well Water from the Yucca Mountain Region," Los Alamos National Laboratory report LA-12563-MS (1994).

16. Polzer W. L., E. H. Essington, K. M. Fellenz and J. R. McLeod, "The Use of Selectivity Coefficients to Estimate Modified Langmuir Isotherm Parameters as a Function of Experimental Conditions," Radioactive Waste Management and Environmental Restoration 19, 107-128 (1994).

17. Reimus, P. W., B. A. Robinson, H. E. Nuttall, and R. Kale, "Transport of Synthetic Colloids and a Nonsorbing Solute through a Saturated Natural Fracture," in Proceedings of the March 1994 meeting of the American Chemical Society, San Diego CA, (1994).

18. Robinson, B. A., “A Strategy for Validating a Conceptual Model for Radionuclide Migration in the Saturated Zone Beneath Yucca Mountain," Radioactive Waste Management and Environmental Restoration 19, 73-96 (1994)

19. Vaniman D. T., S. J. Chipera, and D. L. Bish, "Pedogenesis of Siliceous Calcretes at Yucca Mountain, Nevada," Geoderma 63, 1-17 (1994).

20. Vaniman, D. T., "Calcite Deposits in Drill Cores USW G-2 and USW GU-3/G-3 at Yucca Mountain, Nevada: Preliminary Report," Los Alamos National Laboratory report LA-12720-MS (1994).

21. Vaniman, D. T., and J. F. Whelan, "Inferences of Paleoenvironment from Petrographic, Chemical and Stable-Isotope Studies of Calcretes and Fracture Calcites," in High Level Radioactive Waste Management: Proceedings of the Fifth Annual International Conference, Las Vegas, Nevada, May 22-26, 1994, (American Nuclear Society, La Grange Park, Illinois, 1994), pp. 2730-2737.

22. Whelan, J. F., D. T. Vaniman, J. S. Stuckless, and R. J. Moscati, "Paleoclimatic and Paleohydrologic Records from Secondary Calcite: Yucca Mountain, Nevada," in High Level Radioactive Waste Management: Proceedings of the Fifth Annual International Conference, Las Vegas, Nevada, May 22-26, 1994 (American Nuclear Society, La Grange Park, Illinois, 1994), pp. 2738-2745. 


\section{3}

1. Bish, D. L., "Studies of Clays and Clay Minerals Using X-ray Powder Diffraction and the Rietveld Method," in Computer Applications to X-ray Powder Diffraction Analysis of Clay Minerals, CMS Workshop Lectures 5, R. C. Reynolds, Jr. and J. R. Walker, Eds. (Clay Minerals Society, Boulder, Colorado, 1993), pp. 79-122.

2. Bish, D. L., and J. Aronson, "Paleogeothermal and Paleohydrologic Conditions in Silicic Tuff from Yucca Mountain, Nevada," Clays and Clay Minerals 41, 148-161 (1993).

3. Bish, D. L., and G. D. Guthrie, Jr., "Mineralogy of Clay and Zeolite Dusts (Exclusive of 1:1 Layer Silicates)" in Health Effects of Mineral Dusts, Reviews in Mineralogy 28, G. D. Guthrie, Jr., and B. T. Mossman, Eds. (Mineralogical Society of America, Washington, D. C., 1993), pp. 139-184.

4. Bish, D. L., and J. E. Post, "Quantitative Mineralogical Analysis Using the Rietveld FullPattern Fitting Method," American Mineralogist 78, 932-940 (1993).

5. Blacic, J. D., "Hydration Swelling Effects on Time-Dependent Deformation of Zeolitized Tuff," Journal of Geophysical Research 98, 15,909-15,917 (1993).

6. Bolivar, S. L., "The Quality Assurance Liaison: Combined Technical and Quality Assurance Support," in The 17th Annual 1993 Rocky Mountain Quality Conference Denver, Colorado, June 6-8, 1993, pp. 97-104 (1993).

7. Broxton, D. E., S. J. Chipera, F. M. Byers, Jr., and L. A. Rautman, "Geological Evaluation of Six Nonwelded Tuff Sites in the Vicinity of Yucca Mountain, Nevada, for a Surface-based Test Facility for the Yucca Mountain Project," Los Alamos National Laboratory report LA-12542-MS (1993).

8. Carlos, B., D. Bish, S. Chipera, and S. Craven, "Fracture- Lining Manganese Oxide Minerals in a Silicic Tuff," Chemical Geology 107, 47-69 (1993).

9. Chipera, S. J., G. D. Guthrie, Jr., and D. L. Bish, "Preparation and Purification of Mineral Dusts," in Health Effects of Mineral Dusts, Reviews in Mineralog, 28, G. D. Guthrie, Jr., and B. T. Mossman, Eds. (Mineralogical Society of America, Washington, D. C., 1993), pp. 235-250.

10. Conca, J. L., "Measurement of Unsaturated Hydraulic Conductivity in Yucca Mountain Tuff," Los Alamos National Laboratory report LA-12596-MS (1993).

11. Cowan, D., V. Priest, and S. Levy, "ESR Dating of Quartz from Exile Hill, Nevada," Applied Radiation and Isotopes 44, 1035-1039 (1993).

12. Crowe, B. M., F. V. Perry, G. A. Valentine, P. C. Wallmann and R. Kossik, "Simulation Modeling of the Probability of Magmatic Disruption of the Potential Yucca Mountain Site," in Proceedings: Site Characterization and Model Validation Focus '93 (American Nuclear Society La Grange Park, Illinois, 1993) pp. 182-191. 
13. Department of Energy, "Evaluation of the Potentially Adverse Condition Evidence of Extreme Erosion during the Quaternary Period at Yucca Mountain," DOE report YMP/92-41-TPR (1993).

14. Duffy, C. J., "Kinetics of Silica-Phase Transitions," Los Alamos National Laboratory report LA-12564-MS (1993).

15. Duffy, C. J., "Preliminary Conceptual Model for Mineral Evolution in Yucca Mountain," Los Alamos National Laboratory report LA-12708-MS (1993).

16. Elkins, N., "Prioritization of ESF Testing and Integration with Design and Construction," in High Level Waste Management: Proceedings of the Fourth Annual International Conference, Las Vegas, Nevada, April 26-30, 1993 (American Nuclear Society, La Grange Park, Illinois, 1993), pp. 521-523.

17. Fabryka-Martin, J. T., S. J. Wightman, W. J. Murphy, M. P. Wickham, M. W. Caffee, G. J. Nimz, J. R. Southon, and P. Sharma, "Distribution of Chlorine-36 in the Unsaturated Zone at Yucca Mountain: an Indicator of Fast Transport Paths," in Proceedings: Site Characterization and Model Validation Focus '93 (American Nuclear Society, La Grange Park, Illinois, 1993) pp. 58-68.

18. Guthrie, G. D. Jr., and B. T. Mossman, Eds., Health effects of mineral dusts, Reviews in Mineralogy 28, (Mineralogical Society of America, Washington, D. C., 1993).

19. Hersman, L. E., P. D. Palmer, and D. E. Hobart, "The Role of Siderophores in the Transport of Radionuclides," in Materials Research Society Symposium Proceedings November 30 -December 4, 1993294 (Materials Research Society, Pittsburgh, Pennsylvania, 1993), pp. 765-770.

20. Kalia, H. N., "Control of Tracer, Fluids, and Materials for the Yucca Mountain Site Characterization Project," High Level Waste Management: Proceedings of the Fourth Annual International Conference, Las Vegas, Nevada, April 26-30, 1993 (American Nuclear Society, La Grange Park, Illinois, 1993), pp. 524-529.

21. Kalia, H. N., "Acquisition of Test Data from the Exploratory Studies Facility for the Yucca Mountain Site Characterization," Symposium on Mine Mechanization and Automation, June 7-10, 1993 at Lulea, Sweden (1993).

22. Levy, S. S., "Natural Gels in the Yucca Mountain Area, Nevada, USA," in Applied Clay Science 7, 79-85 (1993).

23. Levy, S. S., "Surface-Discharging Hydrothermal Systems at Yucca Mountain -Examining the Evidence (3341)," in Materials Research Society Symposium Proceedings 294, (Materials Research Society, Pittsburgh, Pennsylvania, 1993), pp. 543-548.

24. Levy, S. S., and Valentine G. A., "Natural Alteration in the Cooling Topopah Spring Tuff, Yucca Mountain Nevada, as an Analog to a Waste-Repository Hydrothermal Regime," in Proceedings: Site Characterization and Model Validation Focus '93 (American Nuclear Society La Grange Park, Illinois, 1993), pp. 145-149. 
25. Loeven, C., "A Summary and Discussion of Hydrologic Data from the Calico Hills Nonwelded Hydrogeologic Unit at Yucca Mountain, Nevada," Los Alamos National Laboratory report LA-12376-MS (1993).

26. Meijer, A., "Far-Field Transport of Carbon Dioxide Retardation Mechanisms and Possible Validation Experiments," Proceedings: Site Characterization and Model Validation Focus '93 (American Nuclear Society, La Grange Park, Illinois, 1993), pp. 110-112.

27. Nitsche, H., K. Roberts, T. Prussin, D. Keeney, S. A. Carpenter, K. Becraft, and R. C. Gatti, "Radionuclide Solubility and Speciation Studies for the Yucca Mountain Site Characterization Project," in High Level Waste Management: Proceedings of the Fourth Annual International Conference, Las Vegas, Nevada, April 26-30, 1993 (American Nuclear Society, La Grange Park, Illinois, 1993), pp. 1490-1495.

28. Nitsche, H. N., R. C. Gatti, E. M. Standifer, S. C. Lee, A. Muller, T. Prussin, R. S. Deinhammer, H. Maurer, K. Becraft, S. Leung, and S. A. Carpenter, "Measured Solubilities and Speciations of Neptunium, Plutonium, and Americium in a Typical Groundwater (J-13) from the Yucca Mountain Region," Los Alamos National Laboratory report LA-12562-MS (1993).

29. Oliver, R. D., and H. N. Kalia, "Status Report on ESF-Related Prototype Testing," Los Alamos National Laboratory report LA-12411-SR (1993).

30. Reimus, P., R. Glass, and B. Robinson, "Aperture Characteristics, Saturated Fluid Flow, and Tracer Transport Calculations for a Natural Fracture," in High Level Waste Management: Proceedings of the Fourth Annual International Conference, Las Vegas, Nevada, April 26-30, 1993 (American Nuclear Society, La Grange Park, Illinois, 1993), pp. 2009-2016.

31. Reneau, S. "Manganese Accumulation in Rock Varnish in a Desert Piedmont, Mojave Desert, California, and Application to Evaluating Varnish Development," Quaternary Research 40, 309-317 (1993).

32. Reneau, S., R. Raymond Jr., and C. D. Harrington, "Elemental Relationships in Rock Varnish Stratigraphic Layers, Cima Volcanic Field, California: Implications for Varnish Development and the Interpretation of Varnish Chemistry," American Journal of Science 292, 684-723 (1993).

33. Rogers, P. Z., and A. Meijer, "Dependence of Radionuclide Sorption on Sample Grinding, Surface Area, and Water Composition (3009), in High Level Waste Management: Proceedings of the Fourth Annual International Conference, Las Vegas, Nevada, April 26-30, 1993 (American Nuclear Society, La Grange Park, Illinois, 1993), pp. 1509-1516.

34. Springer, E. P., M. D. Siegel, P. L. Hopkins, and R. J. Glass, “Testing models of flow and transport in unsaturated porous media," in High Level Waste Management: Proceedings of the Fourth Annual International Conference, Las Vegas, Nevada, April 26-30, 1993 (American Nuclear Society, La Grange Park, Illinois, 1993), pp. 336-347. 
35. Tait, C. D., D. E. Morris, S. A. Ekberg, and P. D. Palmer, "Speciation of Pu(IV) in Carbonate Media," in Program of the Materials Research Society, November 30December 4, 1992 (Materials Research Society, Pittsburgh, Pennsylvania, 1993), p. 595.

36. Triay, I. R., B. A. Robinson, R. M. Lopez, A. J. Mitchell, and C. M. Overly, "Neptunium Retardation with Tuffs and Ground-waters from Yucca Mountain," in High Level Waste Management: Proceedings of the Fourth Annual International Conference, Las Vegas, Nevada, April 26-30, 1993 (American Nuclear Society, La Grange Park, Illinois, 1993), pp. 1504-1508.

37. Triay, I. R., K. H. Birdsell, A. J. Mitchell, and M. A. Ott, "Diffusion of Sorbing and Nonsorbing Radionuclides in Tuff," in High Level Waste Management: Proceedings of the Fourth Annual International Conference, Las Vegas, Nevada, April 26-30, 1993 (American Nuclear Society, La Grange Park, Illinois, 1993), pp. 1527-1532.

38. Triay, I. R., M. A. Ott, A. J. Mitchell, and C. M. Overly, "Transport of Np through Yucca Mountain Tuffs," in Materials Research Symposium Proceedings, November 30 December 4, 1992 294, (Materials Research Society, Pittsburgh, Pennsylvania, 1993), pp. 543-548.

39. Triay, I. R., M. A. Ott, A. J. Mitchell, and C. M. Overly, "Transport of Neptunium through Yucca Mountain Tuffs," in Scientific Basis for Nuclear Waste Management XVI, C. J. Interrante and R. T. Pabalan, Eds. (Materials Research Society, Pittsburgh, Pennsylvania, 1993), pp. 797-802.

40. Valentine G. A, K. R. Groves, C. W. Gable, F. B. Perry, and B. M. Crowe, "Effects of Magmatic Processes on the Potential Yucca Mountain Repository: Field and Computational Studies," in Proceedings: Site Characterization and Model Validation Focus '93 (American Nuclear Society La Grange Park, Illinois, 1993) pp. 167-173.

41. Vaniman, D. T., "Calcite Deposits in Fractures at Yucca Mountain, Nevada," in High Level Waste Management: Proceedings of the Fourth Annual International Conference, Las Vegas, Nevada, April 26-30, 1993 (American Nuclear Society, La Grange Park, Illinois, 1993), pp. 1935-1939.

42. Vaniman, D., D. L. Bish, and S. Chipera, "Dehydration and Rehydration of a Tuff Vitrophyre," in Journal of Geophysical Research 98, 22,309 - 22,320 (1993).

43. Whitney, J. W., and C. D. Harrington, "Relict Colluvial Boulder Desposits as Paleoclimatic Indicators in the Yucca Mountain Region, Southern Nevada," Geological Society of America Bulletin 105, 1008-1018 (1993).

44. WoldeGabriel, G., D. E. Broxton, D. L. Bish, and S. J. Chipera, "Mineralogy and Clinoptilolite K/Ar Results from Yucca Mountain, Nevada, USA: A Potential High-Level Radioactive Waste Repository Site," Los Alamos National Laboratory report LA-12652MS (1993). 
1. Birdsell, K. H., K. Campbell, K. G. Eggert, and B. J. Travis, "Sensitivity Analysis of Integrated Radionuclide Transport Based on a Three-dimensional Geochemical/Geophysical Model," in Proceedings of the DOE/Yucca Mountain Site Characterization Project Radionuclide Adsorption Workshop at Los Alamos National Laboratory, September 11-12, 1990, J. A. Canepa, Compiler, Los Alamos National Laboratory report LA-12325-C, pp. 187-224 (1992).

2. Bolivar, S. L., "Los Alamos National Laboratory, Yucca Mountain Site Characterization Project 1991 Quality Program Status Report," Los Alamos National Laboratory report LA-12344-MS (1992).

3. Bolivar, S. L., and J. L. Day, "The Role of the Los Alamos National Laboratory's Yucca Mountain Site Characterization Project," in Proceedings of the Nineteenth Annual National Energy \& Environmental Quality Division Conference, Lake Buena Vista, Florida, September 20-23, (1992).

4. Broxton, D. E., "Chemical Changes Associated with Zeolitization on the Tuffaceous Beds of Calico Hills at Yucca Mountain, Nevada," in Water-Rock Interaction, Proceedings of the 7th International Symposium on Water-Rock Interaction, WRI-7, Park City Utah, USA, 13-18 July 1992 (A. A. Balkema, Rotterdam and Brookfield, Capetown, South Africa, 1992), pp. 699-703.

5. Canepa, J. A., Compiler, "Proceedings of the DOE/Yucca Mountain Site Characterization Project Radionuclide Adsorption Workshop at Los Alamos National Laboratory, September 11-12, 1990," Los Alamos National Laboratory Report LA-12325-C (1992).

6. Combes, J. M., C. J. Chisholm-Brause, G. E. Brown, Jr., G. A. Parks, S. D. Conradson, P. G. Eller, I. R. Triay, D. E. Hobart, and A. Meijer, "X-ray Adsorption Spectroscopy Study of Neptunium(V) Sorbed at the $\alpha-\mathrm{FeOOH} /$ Water Interface," Environmental Science and Technology 26, 376-382 (1992).

7. Crowe, B. M., G. Valentine, R. A. Morley and F. V. Perry, "Recent Progress in Volcanism Studies: Site Characterization Activities for the Yucca Mountain Project," in Waste Management '92 1 (Arizona Board of Regents, Tucson, Arizona, 1992), pp. 921-928.

8. Crowe, B. M., R. Picard, G. Valentine, and F. V. Perry, "Recurrence Models of Volcanic Events: Application to Volcanic Risk Assessment," in High Level Radioactive Waste Management: Proceedings of the Third International Conference, Las Vegas, Nevada, April 12-16, 1992 (American Nuclear Society, La Grange Park, Illinois, 1992), pp. 2344-2355.

9. Crowe B. M., R. A. Morley, S. G. Wells, J. Geissman, E. McDonald, L. McFadden, F. V. Perry, M. Murrell, J. Poths, and S. Forman, "The Lathrop Wells Volcanic Center: Status of Field and Geochronology Studies," in High Level Radioactive Waste Management: Proceedings of the Third International Conference, Las Vegas, Nevada, April 12-16, 1992 (American Nuclear Society, La Grange Park, Illinois, 1992) pp. 19972013. 
10. Ebinger, M. H., "Water-Rock Interactions and the pH Stability of Groundwaters from Yucca Mountain, Nevada," in Water-Rock Interaction, Proceedings of the 7th International Symposium on Water-Rock Interaction, WRI-7, Park City Utah, USA, 13-18 July 1992, (A. A. Balkema, Rotterdam and Brookfield, Capetown, South Africa, 1992), pp. 783-786.

11. Guthrie, G. D., Jr., "Biological Effects of Inhaled Minerals," American Mineralogist, 77 pp. 225-243 (1992).

12. Meijer, A., "A Strategy for the Derivation and Use of Sorption Coefficients in Performance Assessment Calculations for the Yucca Mountain Site," in Proceedings of the DOE/Yucca Mountain Site Characterization Project Radionuclide Adsorption Workshop at Los Alamos National Laboratory, September 11-12, 1990, J. A. Canepa, Compiler, Los Alamos National Laboratory report LA-12325-C, pp. 9-40 (1992).

13. Perry, F. V., and B. M. Crowe, "Geochemical Evidence for Waning Magmatism and Polycyclic Volcanism at Crater Flat, Nevada," in High Level Radioactive Waste Management: Proceedings of the Third International Conference, Las Vegas, Nevada, April 12-16, 1992 (American Nuclear Society, La Grange Park, Illinois, 1992), p. 2356.

14. Polzer, W. L., M. G. Rao, H. R. Fuentes, and R. J. Beckman "Thermodynamically Derived Relationships Between the Modified Langmuir Isotherm and Experimental Parameters," Environmental Science and Technology 26, 1780-1786 (1992).

15. Simmons, A. M., and J. A. Canepa, "Recent Developments in the Integrated Approach Toward Characterization of Radionuclide Transport, Yucca Mountain, Nevada," in Waste Management '92 1 (Arizona Board of Regents, Tucson, Arizona, 1992), pp. 947-951.

16. Stuckless J. S., Z. E. Peterman, R. M. Forester, J. F. Whelan, D. T. Vaniman, B. D. Marshall, and E. M. Taylor, "Characterization of Fault-Filling Deposits in the Vicinity of Yucca Mountain, Nevada," in WM '92 Conference Proceedings, Tucson Arizona March 1-5, 929-935 (1992).

17. Triay, I. R., A. J. Mitchell, and M. A. Ott, "Radionuclide Migration Studies for Validation of Batch Sorption Date," in Proceedings of the DOE/Yucca Mountain Site Characterization Project Radionuclide Adsorption Workshop at Los Alamos National Laboratory, September 11-12, 1990, J. A. Canepa, Compiler, Los Alamos National Laboratory report LA-12325-C, pp. 91-109 (1992).

18. Valentine, G., B. M. Crowe, and F. V. Perry, "Physical Processes and the Effects of Magmatism in the Yucca Mountain Region," in High Level Radioactive Waste Management: Proceedings of the Third International Conference, Las Vegas, Nevada, April 12-16, 1992, (American Nuclear Society, La Grange Park, Illinois, 1992), pp. 2014-2024.

19. Vaniman, D. T., D. L. Bish, M. H. Ebinger, and S. J. Chipera, "Precipitation of Calcite, Dolomite, Sepiolite, and Silica from Evaporated Carbonate and Tuffaceous Waters of Southern Nevada," in Water-Rock Interaction, Proceedings of the 7th International Symposium on Water-Rock Interaction, WRI-7, Park City Utah, USA, 13-18 July 1992, (A. A. Balkema, Rotterdam and Brookfield, Capetown, South Africa, 1992) pp. 687-692. 
20. Wells, S. G., and B. M. Crowe, "Measuring the Age of the Lathrop Wells Volcanic Center at Yucca Mountain," Science 257, 555-556 (1992).

21. WoldeGabriel, G., D. E. Broxton, D. L. Bish, S. J. Chipera, "Preliminary Assessment of Clinoptilolite K/Ar Results from Yucca Mountain, Nevada: a Potential High-Level

Radioactive Waste Repository Site," in Water-Rock Interaction, Proceedings of the 7th International Symposium on Water-Rock Interaction, WRI-7, Park City Utah, USA, 13-18 July 1992 (A. A. Balkema, Rotterdam and Brookfield, Capetown, South Africa, 1992), pp. 457-461.

22. Zyvoloski, G. A., Z. V. Dash, and S. M. Kelkar, "FEHMN 1.0: Finite Element Heat and Mass Transfer Code," Los Alamos National Laboratory report LA-12062-MS (1992). 


\section{1}

1. Birdsell, K. H., and B. J. Travis, "Results of the COVE2a Benchmarking Calculations Run with TRACR3D," Los Alamos National Laboratory report LA-11513-MS (1991).

2. Bish, D. L., and S. J. Chipera, "Detection of Trace Amounts of Erionite Using X-ray Powder Diffraction: Erionite in Tuffs of Yucca Mountain, Nevada, and Central Turkey," Clay and Clay Minerals 39, 437-445 (1991).

3. Bolivar, S. L, and J. D. Day, "Say the Right Thing," 17 minute video tape for Yucca Mountain Project describing auditing techniques, EES-13 document (1991).

4. Carlos, B. A., D. L. Bish, and S. J. Chipera, "Distribution of Fracture-lining Minerals at Yucca Mountain," in U.S. Geological Survey Committee for the Advancement of Science in the Yucca Mountain Project Symposium of Fracture, Hydrology and Yucca Mountain, U. S. Geological Survey Open-File Report 91-125 (1991) pp. 18-19.

5. Carlos, B. A., D. L. Bish, and S. J. Chipera, "Fracture-Lining Minerals in the Lower Topopah Spring Tuff at Yucca Mountain," in High Level Radioactive Waste Management: Proceedings of the Second Annual International Conference, Las Vegas, Nevada, April 28-May 3, 1991 (American Nuclear Society, La Grange Park, Illinois, 1991), pp. $486-493$.

6. Crowe, B. M., and F. V. Perry, "Preliminary Geologic Map of the Sleeping Butte Volcanic Centers," Los Alamos National Laboratory report LA-12101-MS (1991).

7. Dagan, G., V. Nguyen, and E. Springer, "Analysis of Solute Transport in an IntermediateScale Unsaturated Flow Experiment," High Level Radioactive Waste Management: Proceedings of the Second Annual International Conference, Las Vegas, Nevada, April 28-May 3, 1991 (American Nuclear Society, La Grange Park, Illinois, 1991), pp. 837844.

8. Hawley, M. E., I. D. Raistrick, J. G. Geery, and R. J. Houlton, "Growth Mechanism of Sputter Films of $\mathrm{YBa}_{2} \mathrm{Cu}_{3} \mathrm{O}_{7}$ Studied by Scanning Tunneling Microscopy," Science 251, 1587-1589 (1991).

9. Levy, S. S., "Mineralogic Alteration History and Paleohydrology at Yucca Mountain, Nevada," in High Level Radioactive Waste Management: Proceedings of the Second Annual International Conference, Las Vegas, Nevada, April 28-May 3, 1991 (American Nuclear Society, La Grange Park, Illinois, 1991), pp. 477-485.

10. Newman, B. D., H. R. Fuentes, and W. L. Polzer, "An Evaluation of Lithium Sorption Isotherms and their Application to Groundwater Transport," Groundwater 20, 818-824 (1991).

11. Nitsche, H., "Basic Research for Assessment of Geologic Nuclear Waste Repositories: What Solubility and Speciation Studies of Transuranium Elements Can Tell Us," in Scientific Basis for Nuclear Waste Management XIV, Materials Research Society Symposium Proceedings, 212, 517-529 (1991). 
12. Nitsche, H., "Solubility Studies of Transuranium Elements for Nuclear Waste Disposal; Principles and Overview," Chemistry and Migration Behavior of Actinides and Fission Products in the Geosphere, Second International Conference, Monterey, California, Nov. 6-10, 1989, Radiochimica Acta 52/53, 3-8 (1991).

13. Nitsche, H., R. C. Gatti, and S. C. Lee, "Low-Level Determination of Plutonium by Gamma and L-X-ray Spectroscopy," in Proceedings of International Topical Conference on Methods and Applications of Radioanalytical Chemistry-II, April 21-27, 1991, Kona, Hawaii, 401-411 (1991).

14. Nitsche, H., "The Importance of Transuranium Solids in Solubility Studies for Nuclear Waste Repositories," in International Symposium on the Scientific Basis for Nuclear Waste Management XV, U. S. and European Materials Research Societies Meeting, Strasbourg, France November 5-8, 289-298 (1991).

15. Nuttall H. E., R. Jain, and Y. Fertelli, "Radiocolloid Transport in Saturated and Unsaturated Fractures," High Level Radioactive Waste Management: Proceedings of the Second Annual International Conference, Las Vegas, Nevada, April 28-May 3, 1991, (American Nuclear Society, La Grange Park, Illinois, 1991), pp. 189-196.

16. Polzer, W. L., and H. R. Fuentes, "Fitting a Modified Langumuir Isotherm to Data from Batch Sorption Experiments for Radionuclides on Tuffs," Radiochimica Acta 52/53, 177-179 (1991).

17. Reneau, S., R. Raymond, Jr., and C. D. Harrington, "Cation-Ratio Dating of Rock Varnish: Why Does it Work?" Geology 19, 937-940 (1991).

18. Rundberg, R. S., I. R. Triay, M. A. Ott, and A. J. Mitchell, "Observation of Time Dependent Dispersion in Laboratory Scale Experiments with Intact Tuff," in Chemistry and Migration Behavior of Actinides and Fission Products in the Geosphere, Second International Conference Monterey, CA, Nov. 6-10, 1989, Radiochimica Acta 52/53, 219-228 (1991).

19. Rundberg, R. S., "A Suggested Approach Toward Measuring Sorption and Applying Sorption Data to Repository Performance Assessment," in Proceedings of the NEA Sorption Workshop Held at Interlaken, Switzerland, October 14-19, 1991, 187-215 (1991).

20. Skaggs, B. J., L. W. Ortiz, D. J. Burton, B. L. Isom, and E. A. Vigil, "Evaluation of DustRelated Health Hazards Associated with Air Coring at G-Tunnel, Nevada Test Site," Los Alamos National Laboratory report LA-11594-MS (1991).

21. Travis, B. J., and K. H. Birdsell, "TRACR3D: A Model of Flow and Transport in Porous Media, Model Description and User's Manual," Los Alamos National Laboratory report LA-11798-M (1991).

22. Triay, I. R., A. J. Mitchell, and M. A. Ott, "Radionuclide Migration as a Function of Mineralogy," in High Level Radioactive Waste Management: Proceedings of the Second Annual International Conference, Las Vegas, Nevada, April 28-May 3, 1991 (American Nuclear Society, La Grange Park, Illinois, 1991), pp. 494-498. 
23. Triay, I. R., D. E. Hobart, A. J. Mitchell, T. W. Newton, M. A. Ott, P. D. Palmer, R. S. Rundberg, and J. L. Thompson, "Size Determination of Plutonium Colloids Using Autocorrelation Photon Spectroscopy," in Chemistry and Migration Behavior of Actinides and Fission Products in the Geosphere, Second International Conference Monterey, California, November 6-10, 1989, Radiochimica Acta 52/53, 127-131 (1991).

24. Triay, I. R., A. Meijer, M. R. Cisneros, G. G. Miller, A. J. Mitchell, M. A. Ott, D. Hobart, P. D. Palmer, R. E. Perrin, and D. R. Aguilar, "Sorption of Americium in Tuff and Pure Minerals Using Synthetic and Natural Groundwaters," in Chemistry and Migration Behavior of Actinides and Fission Products in the Geosphere, Second International Conference Monterey, California, Nov. 6-10, 1989, Radiochimica Acta 52/53, 141-145 (1991).

25. Wells, S. G., L. D. McFadden, C. E. Renault, and B. M. Crowe, "Reply on Geomorphic Assessment of Late Quaternary Volcanism in the Yucca Mountain Area, Southern Nevada: Implications for the Proposed High-Level Radioactive Waste Repository," Geology 19, 661-662 (1991). 
1. Birdsell, K. H., K. Campbell, K. G. Eggert, and B. J. Travis, "Simulation of Radionuclide Retardation at Yucca Mountain Using Stochastic Mineralogical/Geochemical Model," in High Level Radioactive Waste Management: Proceedings of the First Annual International Topical Meeting, April 8-12, 1990 (American Nuclear Society, La Grange Park, Illinois, 1990), pp. 153-162.

2. Bish, D. L., "Long-Term Thermal Stability of Clinoptilolite: The Development of a "B" Phase," European Journal of Mineralogy 2, $771-777$ (1990).

3. Bish, D. L., "Thermal Stability of Zeolitic Tuff from Yucca Mountain, Nevada," in High Level Radioactive Waste Management: Proceedings of the First Annual International Topical Meeting April 8-12, 1990 (American Nuclear Society, La Grange Park, Illinois, 1990), pp. 596-602.

4. Bolivar, S. B., D. E. Broxton, D. L. Bish, F. M. Byers, B. A. Carlos, S. S. Levy, and T. Vaniman, "Mineralogy-Petrology Studies and Natural Barriers at the Yucca Mountain, Nevada," in Proceedings of the Nuclear Waste Isolation in the Unsaturated Zone, Focus '89 Conference (American Nuclear Society, La Grange Park, Illinois, 1990), pp. 125 133.

5. Carlos, B. A., D. L. Bish, and S. J. Chipera, "Manganese-Oxide Minerals in Fractures of the Crater Flat Tuff in Drill Core USW-G-4," Los Alamos National Laboratory report LA-11787-MS (1990).

6. Conca, J. L., "Diffusion Barrier Properties of Unsaturated Paintbrush Tuff Rubble Backfill," High Level Radioactive Waste Management: Proceedings of the First Annual International Topical Meeting, April 8-12, 1990 (American Nuclear Society, La Grange Park, Illinois, 1990), pp. 394-401.

7. Conca, J. L., and J. Wright, "Effect of Meteoric Infiltration on the Aqueous Chemistry of Paintbrush Tuff During Exposure at the Surface," Radioactive Waste Management and the Nuclear Fuel Cycle 15, 27-41 (1990).

8. Crowe, B. M., "Basaltic Volcanic Episodes of the Yucca Mountain Region," in High Level Radioactive Waste Management: Proceedings of the First Annual International Topical Meeting April 8-12, 1990 (American Nuclear Society, La Grange Park, Illinois, 1990), pp. $65-73$.

9. Crowe, B. M., and F. V. Perry, "Volcanic Probability Calculations for the Yucca Mountain Site: Estimation of Volcanic Rates," in Proceedings of the Nuclear Waste Isolation in the Unsaturated Zone, Focus '89 Conference (American Nuclear Society, La Grange Park, Illinois, 1990), pp. 324-326.

10. Hobart, D. E., D. E. Morris, P. D. Palmer, and T. Newton, "Formation, Characterization, and Stability of Pu(IV) Colloid," in Proceedings of the Nuclear Waste Isolation in the Unsaturated Zone, Focus '89 Conference (American Nuclear Society, La Grange Park, Illinois, 1990), pp. 118-124. 
11. Janecky, D. R., R. S. Rundberg, M. A. Ott, and A. J. Mitchell "Update Report on Fracture Flow in Saturated Tuff; Dynamic Transport Task for the Nevada Nuclear Waste Investigations," Los Alamos National Laboratory report LA-11957-MS (1990).

12. Kalia, H. N., "Role of Underground Testing to Determine Suitability of Yucca Mountain as a Potential Repository Site," In High Level Radioactive Waste Management: Proceedings of the First Annual International Topical Meeting, April 8-12, 1990 (American Nuclear Society, La Grange Park, Illinois, 1990), pp. 843-847.

13. Kalia, H. N., and N. Z. Elkins, "Characterization Testing Support Requirements for the Exploratory Shaft Facility at Yucca Mountain," International Conference on Shaft Drilling Technology, May 2-4, 9 (1990).

14. Kalia H. N., and W. A. Girdley, "Prototype Testing for the Yucca Mountain Project," in High Level Radioactive Waste Management: Proceedings of the First Annual International Topical Meeting April 8-12, 1990 (American Nuclear Society, La Grange Park, Illinois, 1990), pp. 843-847.

15. Kalia, H. N., and T. J. Merson, "Exploratory Shaft Facility: Its Role In the Characterization of the Yucca Mountain Site for a Potential Nuclear Waste Repository," International Symposium on Unique Underground Structures, June 12-15, (1990).

16. Kelkar, S., and G. A. Zyvoloski, "Modeling of Coupled Heat-Mass-Stress Effects in Geologic Media," in High Level Radioactive Waste Management: Proceedings of the First Annual International Topical Meeting, April 8-12, 1990 (American Nuclear Society, La Grange Park, Illinois, 1990), pp. 951-920.

17. Meijer, A., "Yucca Mountain Project Far-Field Sorption Studies and Data Needs," Los Alamos National Laboratory report LA-11671-MS (1990).

18. Meijer, A., I. R. Triay, S. Knight, and M. R. Cisneros, "Sorption of Radionuclides on Yucca Mountain Tuffs," in Proceedings of the Nuclear Waste lsolation in the Unsaturated Zone, Focus '89 Conference (American Nuclear Society, La Grange Park, Illinois, 1990), pp. 113-117.

19. Norris, A. E., "The Use of Chlorine Isotope Measurements to Trace Water Movements at Yucca Mountain," in Proceedings of the Nuclear Waste Isolation in the Unsaturated Zone, Focus ' 89 Conference (American Nuclear Society, La Grange Park, Illinois, 1990), pp. 400-405.

20. Patera, E. S., D. E. Hobart, A. Meijer, and R. S. Rundberg, "Chemical and Physical Processes of Radionuclide Migration at Yucca Mountain, Nevada," Journal of Radioanalytical and Nuclear Chemistry 142, 331-347 (1990).

21. Penrose, W. R., W. L. Polzer, E. H. Essington, D. M Nelson, and K. A. Orlandini, "Mobility of Plutonium and Americium Through a Shallow Aquifer in a Semiarid Region," Environmental Science and Technology 24, 228-234 (1990). 
22. Rundberg, R. S., A. J. Mitchell, M. A. Ott, J. Thompson, and I. R. Triay, "Laboratory Studies of Radionuclide Migration in Tuff," in Proceedings of the Nuclear Waste Isolation in the Unsaturated Zone, Focus '89 Conference (American Nuclear Society, La Grange Park, Illinois, 1990), pp. 248-255.

23. Stucki, J. W., and D. L. Bish, Eds., "Thermal Analysis in Clay Science," in The Clay Mineral Society Workshop Lectures 3, 192 pp. (1990).

24. Smyth J. R., A. T. Spaid, and D. L. Bish, "Crystal Structures of a Natural and a Csexchanged Clinoptilolite," American Mineralogist, 75, 522-528 (1990).

25. Wells, S. G., L. D. McFadden, C. E. Renault, and B. M. Crowe, "Geomorphic Assessment of Late Quaternary Volcanism in the Yucca Mountain Area, Southern Nevada: Implications for the Proposed High-Level Radioactive Waste Repository," Geology 18, 549-553 (1990).

26. Zyvoloski, G. A., "Simulation of Heat Transfer in the Unsaturated Zone," in High Level Radioactive Waste Management: Proceedings of the First Annual International Topical Meeting, April 8-12, 1990 (American Nuclear Society, La Grange Park, Illinois, 1990), pp. 611-617. 


\section{9}

1. Bish, D. L., "Evaluation of Past and Future Alterations in Tuff at Yucca Mountain, Nevada, Based on the Clay Mineralogy of Drill Cores USE G-1, G-2, and G-3," Los Alamos National Laboratory report LA-10667-MS (1989).

2. Bish, D. L., and S. J. Chipera, "Revised Mineralogic Summary of Yucca Mountain, Nevada," Los Alamos National Laboratory report LA-11497-MS (1989).

3. Bish, D. L., and J. E. Post, Eds., "Modern Powder Diffraction," Mineralogical Society of America Reviews in Mineralogy 20, 369 pp. (1989).

4. Bish, D. L., and J. E. Post, "Thermal Behavior of Complex, Tunnel-Structure Manganese Oxides," American Mineralogist 74, 177-186 (1989).

5. Broxton, D. E., F. M. Byers, Jr., and R. G. Warren, "Petrography of Phenocryst Chemistry of Volcanic Units at Yucca Mountain: A Comparison of Outcrop and Drill Hole Samples," Los Alamos National Laboratory report LA-11503-MS (1989).

6. Broxton, D. E., R. G. Warren, F. M. Byers, and R. B. Scott, "Chemical and Mineralogic Trends Within the Timber Mountain - Oasis Valley Caldera Complex, Nevada: Evidence for Multiple Cycles of Chemical Evolution in a Long-Lived Magma System," Journal of Geophysical Research 94, 5961-5985 (1989).

7. Campbell, K., D. E. Broxton, and J. Spaw, "Status of Image Analysis Methods to Delineate Stratigraphic Position in the Topopah Spring Member of the Paintbrush Tuff, Yucca Mountain, Nye County, Nevada," Los Alamos National Laboratory report LA11694-MS (1989).

8. Canepa, J. A., and R. J. Herbst, "Geochemistry of the Yucca Mountain Site: An Overview of the Approach to Characterization," in Proceedings of Waste Management ' 89 525-530 (1989).

9. Carlos, B. A., "Fracture-Coating Minerals in the Topopah Spring Member and Upper Tuff of Calico Hills from Drill Hole J-13," Los Alamos National Laboratory report LA11504-MS (1989).

10. Chipera, S. J., and D. L. Bish, "The Occurrence and Distribution of Erionite at Yucca Mountain, Nevada," Los Alamos National Laboratory report LA-11663-MS (1989).

11. Chipera, S. J., and D. L. Bish, "Quantitative X-ray Diffraction Analyses of Samples Used for Sorption Studies by the Isotope and Nuclear Chemistry Division, Los Alamos National Laboratory," Los Alamos National Laboratory report LA-11669-MS (1989).

12. Crowe, B. M., C. D. Harrington, B. Turrin, D. Champion, S. G. Wells, F. V. Perry, L. McFadden, and C. Renault, "Volcanic Hazard Studies for the Yucca Mountain Project," in Proceedings of Waste Management '89, R. B. Post, Ed., pp. 485-491 (1989). 
13. Fuentes, H. R., W. L. Polzer, E. H. Essington, and B. D. Newman, "Characterization of Reactive Tracers for C-Wells Field Experiments I: Electrostatic Sorption Mechanism, Lithium," Los Alamos National Laboratory report LA-11691-MS (1989).

14. Herbst, R. J., and J. A. Canepa, "Assessment of Radionuclide Retardation," Radioactive Waste Management and the Nuclear Fuel Cycle 13, 77-92 (1989).

15. Kranz, R. L., D. L. Bish, and J. D. Blacic, "Hydration and Dehydration of Zeolitic Tuff from Yucca Mountain Nevada," Geophysical Research Letters 16, 1113-1116 (1989).

16. Levy, S. S., and J. R. O'Neil, "Moderate-Temperature Zeolitic Alteration in a Cooling Pyroclastic Deposit," Chemical Geology 76, 321-326 (1989).

17. Moore, L. M., F. M. Byers, and D. E. Broxton, "Statistical Test of Reproducibility and Operator Variance in Thin-Section Modal Analysis of Textures and Phenocrysts in the Topopah Spring Member, Drill Hole USW VH-2, Crater Flat, Nye County, Nevada," Los Alamos National Laboratory report LA-11452-MS (1989).

18. Nitsche, H., E. M. Standifer, and R. J. Silva, "Americium(III) Carbonate Complexation In Aqueous Perchlorate Solution," Radiochimica Acta 46, 185 (1989).

19. Post, J. E., and D. L. Bish, "Rietveld Refinements of the Coronadite Structure," American Mineralogist 74, 913-917 (1989).

20. Robinson, B. A., "A Fracture Network Model for Water Flow and Solute Transport," in 1989 Eastern Multiconference, Tampa Florida, March 28-31, 21 (1989).

21. Roy, D. M., and C. A. Langton, "Studies of Ancient Concrete as Analogs of Cementitious Sealing Materials for a Repository in Tuff," Los Alamos National Laboratory report LA-11527-MS (1989).

22. Scheetz, B. E., and D. M. Roy, "Preliminary Survey of the Stability of Silica-Rich Cementitious Mortars 82-22 and 84-12 with Tuff," Los Alamos National Laboratory report LA-11222-MS (1989).

23. Scheetz, B. E., and D. M. Roy, "Reactivity of a Tuff-Bearing Concrete: CL-40 CON-14," Los Alamos National Laboratory report LA-11532-MS (1989).

24. Thompson, J. L., "Actinide Behavior on Crushed Rock Columns," Journal of Radioanalytical and Nuclear Chemistry 130, 353-364 (1989).

25. Triay, I. R., and R. S. Rundberg, "Application of Deconvolution to the Analysis of Univalent Ion-Exchange Isotherms in Zeolites X and Y," Zeolites 9, 217-223 (1989).

26. Triay, I. R., and R. S. Rundberg, "Deconvolution of Multivalent Cation-Exchange Isotherms," The Journal of Physical Chemistry 93, 5617-5623 (1989). 
1. Beckman, R. J., K. W. Thomas, and B. M. Crowe, "Preliminary Report on the Statistical Evaluation of Sorption Data: Sorption as a Function of Mineralogy, Temperature, Time and Particle Size," Los Alamos National Laboratory report LA-11246-MS (1988).

2. Birdsell, K. H., L. F. Brown, A. E. Norris, G. A. Cederberg, B. J. Travis, and P. G. Stringer, "Modeling Tracer Diffusion In Fractured and Unfractured, Unsaturated, Porous Media," Journal of Contaminant Hydrology 3, (1988).

3. Bischke, S. D., R. Chemburkar, L. F. Brown, B. J. Travis, and D. L. Bish, "The Extraction of Site-Energy Distributions from Temperature-Programmed Desorption Spectra," in American Institute of Chemical Engineers Annual Meeting, Washington, D.C., Nov. 28 - Dec. 2, (1988).

4. Bish, D. L., "Smectite Dehydration and Stability: Applications to Radioactive Waste Isolation at Yucca Mountain, Nevada," Los Alamos National Laboratory report LA-11023-MS (1988).

5. Bish, D. L., and S. A. Howard, "Quantitative Phase Analysis Using the Rietveld Technique," Journal of Applied Crystallography 32, 86-91 (1988).

6. Bish, D. L., "Effects of Composition on the Dehydration Behavior of Clinoptilolite and Heulandite," in Occurrence, Properties and Utilization of Natural Zeolites, D. Kallo and H. S. Sherry, Eds. (Akademiai Kiado, Budapest, 1988), pp. 565-576.

7. Campbell, K., "Statistical Guidelines for Planning a Limited Drilling Program," Los Alamos National Laboratory report LA-11293-MS (1988).

8. Chipera, S. J., and D. L. Bish, "Mineralogy of Drill Hole UE-25p\#1 at Yucca Mountain, Nevada," Los Alamos National Laboratory report LA-11292-MS (1988).

9. Ledergerber, G., R. Herbst, H. U. Zwicky, H. Kutter, and P. Fisher, "Characterization and Quality Control of Uranium-Plutonium Carbide for the AC-3/FFTF Experiment," Journal of Nuclear Materials 153, 189-204 (1988).

10. Nitsche, H., S. C. Lee, and R. C. Gatti, "Determination of Plutonium Oxidation States at Trace Levels Pertinent to Nuclear Waste Disposal," Journal of Radioanalytical and Nuclear Chemistry 124, 1 (1988).

11. Ogard, A. E., J. L. Thompson, R. S. Rundberg, K. Wolfsberg, P. W. Kubik, D. Elmore and H. W. Bentley, "Migration of Chlorine-36 and Tritium from an Underground Nuclear Test," Radiochimica Acta 44/45, 213-217 (1988).

12. Polzer, W. L., and H. R. Fuentes, "The Use of a Heterogeneity-Base Isotherm to Interpret the Transport of Radionuclides in Volcanic Tuff Media," Radochimica Acta 41/45, 361-365 (1988). 
13. Post, J. E., and D. L. Bish, "Rietveld Refinement of the Todorokite Structure," American Mineralogist 73, 861-869 (1988).

14. Rundberg, R. S., A. J. Mitchell, I. R. Triay, B. J. Torstenfeld, M. J. Apted, and E. Westerman, Eds., "Size and Density of a 242Pu Colloid," in Scientific Basis for Nuclear Waste Management XI 112, (Material Research Society Symposium Proceedings:

Pittsburgh, Pennsylvania, 1988), pp. 243-248.

15. Standifer, E. M., and H. Nitsche, "First Evidence for Hexagonal AmOHCO3," Lanthanide and Actinide Research 2, 383 (1988).

16. Thomas, K. W., Compiler, "Research and Development Related to the Nevada Nuclear Waste Storage Investigations, October 1 - December 31, 1984," Los Alamos National Laboratory report LA-11443-PR (1988).

17. Tucker, D. T., E. M. Standifer, and H. Nitsche, "Data Acquisition and Feedback Control System for Solubility Studies of the Nuclear Waste Elements Neptunium and Plutonium," Lanthanide and Actinide Research 2, 279 (1988).

18. Vaniman, D. T., D. L. Bish, and S. J. Chipera, "A Preliminary Comparison of Mineral Deposits in Faults near Yucca Mountain, Nevada, with Possible Analogs," Los Alamos National Laboratory report LA-11289-MS (1988).

19. West, K. A., "Nevada Nuclear Waste Storage Investigation Exploratory Shaft Facility Fluids and Materials Evaluation," Los Alamos National Laboratory report LA-11398-MS (1988). 
1. Bish, D. L., "Problems and Solutions In Quantitative Analysis of Complex Mixtures by X-ray Powder Diffraction," Advances In X-ray Analysis 31, 295-308 (1987).

2. Bish, D. L., "Review of Natural Zeolites," Journal of Sedimentary Petrology 57, 390-391 (1987).

3. Bish, D. L., "Smectite Dehydration and Stability: Applications to Radioactive Waste Isolation at Yucca Mountain, Nevada," Los Alamos National Laboratory report LA-11023-MS (1987).

4. Bish, D. L., "Thermogravimetric Analysis of Minerals," in Workshop on Advanced Methods of Thermal Analysis, (Clay Minerals Society, Socorro, New Mexico, 1987).

5. Broxton D. E., "Clinoptilolite Compositions in Diagenetically-Altered Tuffs at a Potential Nuclear Waste Repository, Yucca Mountain, Nevada," in The Technology of High Level Nuclear Waste Disposal, pp. 179-194 (1987).

6. Broxton, D. E., D. L. Bish, and R. G. Warren, "Distribution and Chemistry of Diagenetic Minerals, Yucca Mountain, Nye County, Nevada," Clays and Clay Minerals 35, 89-110 (1987).

7. Byers, F.M. Jr., and L. M. Moore, "Petrographic Variation of the Topopah Spring Tuff Matrix Within and Between Cored Drill Holes, Yucca Mountain, Nevada," Los Alamos National Laboratory report LA-10901-MS (1987).

8. Campbell, K., "Lateral Continuity of Sorptive Mineral Zones Underlying Yucca Mountain, Nevada," Los Alamos National Laboratory report LA-11070-MS (1987).

9. Carlos, B. A., "Minerals in Fractures of the Saturated Zone from Drill Core USW G-4, Yucca Mountain, Nye County, Nevada," Los Alamos National Laboratory report LA-10927-MS (1987).

10. Finnegan, D. L., and E. A. Bryant, "Methods for Obtaining Sorption Data From Uranium-Series Disequilibria," Los Alamos National Laboratory report LA-11162-MS (1987).

11. Fuentes, H. R., W. L. Polzer, J. Gruber, B. Lauctes, and E. H. Essington, "Preliminary Report on Sorption Modeling," Los Alamos National Laboratory report LA-10952-MS (1987).

12. Gatti, R. C., and S. C. Lee, "Determination of Plutonium Oxidation States at Trace Levels Pertinent to Nuclear Waste Disposal," in Proceedings of International Conference on Methods and Applications of Radioanalytical Chemistry, Kona, Hawaii, April 21-17 1987 .

13. Greenwade, L. E., and G. A. Cederberg, "Preliminary Geochemical/Geophysical Model of Yucca Mountain," in Proceedings of the Materials Research Society Symposium 84, 703-712 (1987). 
14. Harrington, C. D., and J. W. Whitney, "Scanning Electron Microscope Method for Rock-Varnish Dating," Geology 15, 967-970 (1987).

15. Kerrisk, J. F., "Groundwater Chemistry at Yucca Mountain, Nevada, and Vicinity," Los Alamos National Laboratory report LA-10929-MS (1987).

16. McWilliams, T. P., "Sensitivity Analysis of Geologic Computer Models; A Formal Procedure Based on Latin Hypercube Sampling," Mathematical Geology 9, $81-90$ (1987).

17. Norris, A. E., K. Wolfsberg, S. K. Gifford, H. W. Bentley, and D. Elmore, "Infiltration at Yucca Mountain, Nevada, Traced by Cl-36," Nuclear Instruments \& Methods B29, 376-379 (1987).

18. Rundberg, R. S., "Assessment Report on the Kinetics of Radionuclide Adsorption on Yucca Mountain Tuff," Los Alamos National Laboratory report LA-11026-MS (1987).

19. Thomas, K. W., "Summary of Sorption Measurements Performed with Yucca Mountain, Nevada, Tuff Samples and Water from Well J-13," Los Alamos National Laboratory report LA-10960-MS (1987).

20. Travis, B. J., and H. E. Nuttall, "Two-Dimensional Numerical Simulation of Geochemical Transport in Yucca Mountain," Los Alamos National Laboratory report LA-10532-MS (1987).

21. Triay, I. R., and R. S. Rundberg, "Determination of Selectivity Coefficient Distribution by Deconvolution of Ion-Exchange Isotherms," Journal of Physical Chemistry 91, 5269 (1987).

22. Van Eeckhout, E., "Controlled Blasting and Its Implications for the NNWSI Project Exploratory Shaft," Los Alamos National Laboratory report LA-11097-MS (1987).

23. Vaniman, D. T., D. L. Bish, L. Brown, D. E. Broxton, F. M. Byers, B. A. Carlos, J. Chipera, S. S. Levy, P. Stringer, and D. T. Vaniman, "Research by ESS Division for Nuclear Waste Storage Investigations, January - June 1985," Los Alamos National Laboratory report LA-10987-PR (1987). 
1. Bentley, H. W., S. K. Gifford, A. E. Norris, and K. Wolfsberg, "Measurements of Infiltration at Yucca Mountain," Los Alamos National Laboratory report LA-10709-PR (1986).

2. Bish, D. L., and S. J. Chipera, "Mineralogy of Drill Holes J-13, UE-25a\#l, and USW G-1 at Yucca Mountain, Nevada," Los Alamos National Laboratory report LA-10764-MS (1986).

3. Blacic, J. D., D. T. Vaniman, D. L. Bish, C. J. Duffy, and R. C. Gooley, "Effects of Long-Term Exposure of Tuffs to High-Level Nuclear Waste Repository Conditions: Final Report," Los Alamos National Laboratory report LA-9330-MS (1986).

4. Broxton, D. E., and B. A. Carlos, "Zeolitic Alteration and Fracture Fillings in Silicic Tuffs at a Potential Nuclear Waste Repository, Yucca Mountain, Nevada, USA," in Proceeding of Fifth International Symposium on Water-Rock Interaction, Reykjavik, Iceland, August 8-17, pp. 88-91 (1986).

5. Broxton, D. E., R. G. Warren, R. C. Hagan, and G. Luedemann, "Chemistry of Diagenetically Altered Tuffs at a Potential Nuclear Waste Repository, Yucca Mountain, Nye County, Nevada," Los Alamos National Laboratory report LA-10802-MS (1986).

6. Byers, Jr., F. M., and L. M. Moore, "Petrographic Variation of the Topopah Spring Tuff Matrix Within and Between Cored Drill Holes, Yucca Mountain, Nevada," Los Alamos National Laboratory report LA-10901-MS (1986).

7. Carlos, B. A., "Occurrence of Fracture-Lining Manganese Minerals in Silicic Tuffs, Yucca Mountain, Nevada, USA," in Proceedings of Fifth International Symposium on Water-Rock Interaction, Reykjavik, Iceland, August 8-17, pp. 96-99 (1986).

8. Carr, M. D., S. J. Waddell, G. S. Vick, J. M. Stock, S. A. Monsen, A. G. Harris, W. Cork, and F. M. Byers, Jr., "Geology of Drill Hole UE-25p\#1: A Test Hole into Pre-Tertiary Rocks Near Yucca Mountain, Southern Nevada," US Department of the Interior/Geological Survey Report USGS-OF-86-175 (1986).

9. Crowe, B. M., "Volcanic Hazard Assessment for Disposal of High- Level Radioactive Waste," in Active Tectonics (National Academy Press, 1986), pp. 247-260.

10. Crowe, B. M., K. H. Wohletz, D. T. Vaniman, E. Gladney, and N. Bower, "Status of Volcanic Hazard Studies for the Nevada Nuclear Waste Storage Investigations," Los Alamos National Laboratory report LA-9325-MS, Vol. II (1986).

11. Hobart D. E., P. D. Palmer and T. W. Newton, "Carbonate Complexation of Plutonium(IV): The Competition by Citrate Ligands," Los Alamos National Laboratory report LA-11034-PR (1986).

12. Kerrisk, J. F., and R. J. Silva, "A Consistent Set of Thermodynamic Constants for Americium + (III) Species with Hydroxyl and Carbonate," in Proceedings of Workshop on Geochemical Modeling, Fallen Leaf Lake, California, September 14-17, 167-175 (1986). 
13. Levy, S. S., B. A. Carlos, and H. Classen, "Smectite-Zeolite Fracture Filling Caught in the Act?" presented at American Geophysical Union, San Francisco, California, December $8-12,321-326$ (1986).

14. Newton, T. W., D. E. Hobart, and P. D. Palmer, "The Formation of Pu(IV)-Colloid by the Alpha-Reduction of Pu(V) or Pu(VI) in Aqueous Solutions," Radiochimica Acta 39, 139-147 (1986).

15. Norris, A. E., K. Wolfsberg, and S. K. Gifford, " $36 \mathrm{Cl}$ Measurements of the Unsaturated Zone Flux at Yucca Mountain," presented at International Topical Meeting on High Level Nuclear Waste Disposal: Pasco, Washington, September 24-26, 1985, H. C. Burkholder, Ed. (Battelle Press, Columbus, Ohio, 1986), pp. 381-388.

16. Norris, A. E., F. M. Byers, Jr., and T. J. Merson, "Fran Ridge Horizontal Coring Summary Report Hole UE-25h\#1, Yucca Mountain Area, Nye County, Nevada," Los Alamos National Laboratory report LA-10859-MS (1986).

17. Polzer, W. L., H. R. Fuentes, E. P. Springer, and J. W. Nyhan, "Modeling Study of Solute Transport in the Unsaturated Zone: Information and Data Sets," Los Alamos National Laboratory report LA-10730-MS (1986). 
1. Bish, D. L., "The Clay Mineralogy of Drill Cores USW-G1, G2, and G3: Applications To Past and Future Alterations in Tuff," Los Alamos National Laboratory report LA-10667MS (1985).

2. Bish, D. L., and D. T. Vaniman, "Mineralogic Summary of Yucca Mountain, Nevada," Los Alamos National Laboratory report LA-10543-MS (1985).

3. Byers, F. M. Jr., "Petrochemical Variation of Topopah Spring Tuff Matrix with Depth (Stratigraphic Level), Drill Hole USW G-4, Yucca Mountain, Nevada," Los Alamos National Laboratory report LA-10561-MS (1985).

4. Caporuscio, F. A., and D. T. Vaniman, "Iron and Manganese in Oxide Minerals and in Glasses: Preliminary Consideration of Eh Buffering Potential at Yucca Mountain, Nevada," Los Alamos National Laboratory report LA-10369-MS (1985).

5. Caporuscio, F. A., R. G. Warren, and D. E. Broxton, "Detailed Petrographic Descriptions and Microprobe Data for Tertiary Silicic Volcanic Rocks in Drill Hole USW G-1, Yucca Mountain, Nevada," Los Alamos National Laboratory report LA-9323-MS (1985).

6. Carlos, B. A., "Minerals in Fractures of the Unsaturated Zone from Drill Core USW G-4, Yucca Mountain, Nye County, Nevada," Los Alamos National Laboratory report LA-10415-MS (1985).

7. Crowe, B. M., Compiler, "Research and Development Related to the Nevada Nuclear Waste Storage Investigations, January 1 - March 31, 1984," Los Alamos National Laboratory report LA-10154-PR (1985).

8. Kerrisk, J. F., "An Assessment of the Important Radionuclides in Radioactive Waste," Los Alamos National Laboratory report LA-10414-MS (1985).

9. Kerrisk, J. F., "Solubility Experiments for the Nevada Nuclear Waste Storage Investigations Project," Los Alamos National Laboratory report LA-10560-MS (1985).

10. Ogard, A. E., and D. T. Vaniman, Compilers, "Research and Development Related to the Nevada Nuclear Waste Storage Investigations, July 1 - September 30, 1984," Los Alamos National Laboratory report LA-10299-PR (1985).

11. Rundberg, R. S., A. E. Ogard, and D. T. Vaniman, Compilers, "Research and Development Related to the Nevada Nuclear Waste Storage Investigations, April 1 - June 30, 1984," Los Alamos National Laboratory report LA-10297-PR (1985).

12. Travis, B. J., and H. E. Nuttall, “ Analysis of Colloid Transport," In Material Research Society Symposium Proceedings 50, 737-745 (1985). Travis, B. J., and H. E. Nuttall, "A Transport Code for Radiocolloid Migration: With an Assessment of an Actual Low-Level Waste Site," Material Research Society Symposium Proceedings 44, 969-976 (1985). 


\section{4}

1. Bish, D. L., "Effects of Exchangeable Cation Composition on the Thermal Expansion/Contraction Behavior of Clinoptilolite," Clays and Clay Minerals 32, 444-452 (1984).

2. Bish, D. L., D. T. Vaniman, R. S. Rundberg, K. Wolfsberg, W. R. Daniels, and E. Broxton, "Natural Sorptive Barriers in Yucca Mountain, Nevada, for Long Term Isolation of High-Level, Waste," Radioactive Waste Management 3, 415-432 (1984).

3. Bish, D. L., A. E. Ogard, D. T. Vaniman, and L. Benson, "Mineralogy-Petrology and Groundwater Geochemistry of Yucca Mountain Tuffs," in Scientific Basis for Nuclear Waste Management VII, Materials Research Society Symposia Proceedings, G. L. McVay, Ed. (New York, Elsevier Science Pub. Co., 1984), pp. 283-291.

4. Bryant, E. A., and D. T. Vaniman, Compilers, "Research and Development Related to the Nevada Nuclear Waste Storage Investigations; July 1 - September 30, 1983," Los Alamos National Laboratory report LA-10006-PR (1984).

5. Carr, W. J., A. M. Rodgers, and B. M. Crowe, "Nevada Test Site and Vicinity; Tectonics, Seismicity, and Volcanism of the Southern Great Basin," in US Geological Survey WaterResources Investigations Report 84-4205, pp. 19-28 (1984).

6. Duffy, C. J., "Thermodynamic Model for Analcime," Los Alamos National Laboratory report LA-10130-PR (1984).

7. Kerrisk, J. F., "Americium Thermodynamic Data for the EQ3/6 Database," Los Alamos National Laboratory report LA-10040-MS (1984).

8. Kerrisk, J. F., "Solubility Limits on Radionuclide Dissolution at a Yucca Mountain Repository," Los Alamos National Laboratory report LA-9995-MS (1984).

9. Levy, S. S., "Petrology of Samples from Drillholes USW-H3, H4, H5, Yucca Mountain, Nevada," Los Alamos National Laboratory report LA-9706-MS (1984).

10. Levy S. S., "Studies of Altered Vitrophyre for the Prediction of Nuclear Waste Repository-Induced Thermal Alteration at Yucca Mountain, Nevada," in Scientific Basis for Nuclear Waste Management VII (New York, Elsevier Science Pub. Co., 1984), pp. 959-966.

11. Ogard, A. E., "The Nevada Nuclear Waste Storage Investigations," Los Alamos National Laboratory report LA-10130-PR (1984).

12. Ogard, A. E., and J. F. Kerrisk, "Groundwater Chemistry Along Flow Paths Between a Proposed Repository Site and the Accessible Environment," Los Alamos National Laboratory report LA-10188-MS (1984). 
13. Ogard, A. E., P. L. Wanek, S. Maestas, A. J. Mitchell, R. D. Aguilar, and M. R. Cisneros, "Groundwater Chemistry of Yucca Mountain," Los Alamos National Laboratory report LA-10130-PR (1984).

14. Travis, B. J., "TRACR3D: A Model of Flow and Transport in Porous/Fractured Media," Los Alamos National Laboratory report LA-9667-MS (1984).

15. Vaniman, D. T., D. L. Bish, D. E. Broxton, F. M. Byers, Jr., G. H. Heiken, B. A. Carlos, E. Semarge, F. A. Caporuscio, and R. C. Gooley, "Variations in Authigenic Mineralogy and Sorptive Zeolite Abundance at Yucca Mountain, Nevada, Based on Studies of Drill Cores USW GU-3 and G-3," Los Alamos National Laboratory report LA-9707-MS (1984).

16. Warren, R. G., F. M. Byers, Jr., and F. A. Caporuscio, "Petrography and Mineral Chemistry of Units of the Topopah Spring, Calico Hills, and Crater Flat Tuffs, and Older Volcanic Units, with Emphasis on Samples from Drill Holes USW G-1, Yucca Mountain, Nevada Test Site," Los Alamos National Laboratory report LA-10003 (1984).

17. Wolfsberg, K., and D. T. Vaniman, Compilers, "Research and Development Related to the Nevada Nuclear Waste Storage Investigations; October 1 - December 31, 1983," Los Alamos National Laboratory report LA-10032-PR (1984). 
1. Benson, L. V., J. H. Robison, R. K. Blankennagel, and A. E. Ogard, "Chemical Composition of Groundwater and the Locations of Permeable Zones in the Yucca Mountain area, Nevada," US Geological Survey Open-File Report 83-854, p. 19 (1983).

2. Bish, D. L., D. T. Vaniman, R. S. Rundberg, K. Wolfsberg, W. R. Daniels, and D. E. Broxton, "Natural Sorptive Barriers in Yucca Mountain, Nevada, for Long-Term Isolation of High-Level Waste," in Radioactive Waste Management: Proceedings of an International Conference on Radioactive Waste Management held by the international Atomic Energy Agency in Seattle, Washington, May 16, 1983, (International Energy Agency, Vienna, Austria, 1983), pp. 415-432.

3. Blacic, J. D., and R. Andersen, "Methodology for Determining the Time Dependent Mechanical Properties of Tuff Subjected to Near- Field Repository Conditions," Los Alamos National Laboratory report LA-9322-MS (1983).

4. Byers, Jr., F. M., and R. G. Warren, "Revised Volcanic Stratigraphy of Drill Hole J-13, Fortymile Wash, Nevada, Based on Petrographic Modes and the Chemistry of Phenocrysts," Los Alamos National Laboratory report LA-9652-MS (1983).

5. Crowe, B. M., D. T. Vaniman, and W. J. Carr, "Status of Volcanic Hazard Studies for the Nevada Nuclear Waste Storage Investigations," Los Alamos National Laboratory report LA-9325-MS (1983).

6. Crowe, B. M., R. Amos, F. V. Perry, S. Self, and D. T. Vaniman, "Aspects of Potential Magmatic Disruption of a High-Level Radioactive Waste Repository in Southern Nevada," Journal of Geology 91, 259-276 (1983).

7. Daniels, W. R., B. R. Erdal, and D. T. Vaniman, Compilers, "Research and Development Related to the Nevada Nuclear Waste Storage Investigations, July 1 - September 30, 1982," Los Alamos National Laboratory report LA-9577-PR (1983).

8. Erdal, B. R., D. L. Bish, B. M. Crowe, W. R. Daniels, A. E. Ogard, R. S. Rundberg, T. Vaniman, and K. Wolfsberg, "Some Geochemical Considerations for a Potential Repository Site in Tuff at Yucca Mountain, Nevada," in Proceedings of the U.S./F.R.G. Bilateral Workshop, Berlin, West Germany, 21 (1983).

9. Kerrisk, J. F., "Reaction Path Calculations of Groundwater Chemistry and Mineral Formation at Rainier Mesa, Nevada," Los Alamos National Laboratory report LA-9912-MS (1983).

10. Levy, S. S., "Studies of Altered Vitrophyre for the Prediction of Nuclear Waste Repository-Induced Thermal Alteration at Yucca Mountain, Nevada," in Proceedings of the Materials Research Society Annual Meeting, Boston, Massachusetts, November 13-18, (Materials Research Society, Pittsburgh, Pennsylvania, 1983). 
11. Newton, T. W., and V. L. Rundberg, "Disproportionation and Polymerization of Plutonium (IV) in Dilute Aqueous Solutions," in Proceedings of the Materials Research Society Annual Meeting, Boston, Massachusetts, November 13-18, 1983 (Materials Research Society, Pittsburgh, Pennsylvania, 1983), pp. 867-873.

12. Ogard, A. E., W. R. Daniels, and D. T. Vaniman, Compilers, "Research and Development Related to the Nevada Nuclear Waste Storage Investigations, October 1 - December 31, 1982," Los Alamos National Laboratory report LA-9666-PR (1983).

13. Ogard, A. E., K. Wolfsberg, and D. T. Vaniman, Compilers, "Research and Development Related to the Nevada Nuclear Waste Storage Investigations; April 1 - June 30, 1983," Los Alamos National Laboratory report LA-9846-PR (1983).

14. Ogard, A. E., K. Wolfsberg, W. R. Daniels, J. F. Kerrisk, R. S. Rundberg, and K. W. Thomas, "Retardation of Radionuclides by Rock Units Along the Path to the Accessible Environment," in Proceedings of the Materials Research Society Annual Meeting, Boston, Massachusetts, November 13-18, 1983 (Materials Research Society, Pittsburgh, Pennsylvania, 1983), pp. 329-336.

15. Purson, J. D., "Evaluation of Geochemical Properties Used in Area-to-Location Screening for a Nuclear Waste Repository Site at the Nevada Test Site," Los Alamos National Laboratory report LA-9510-MS (1983).

16. Rundberg, R. S., "The Kinetics of the Adsorption of Radionuclides on Tuff from Yucca Mountain, Nevada," in Proceedings of the Materials Research Society Annual Meeting, Boston, Massachusetts, November 13-18, 1983, (Materials Research Society, Pittsburgh, Pennsylvania, 1983), pp. 827-834.

17. Travis, B. J., and T. L. Cook, "Simulation of Flow and Transport in Partially Saturated, Fractured Tuff," in Proceedings of the Materials Research Society Annual Meeting, Boston, Massachusetts, November 13-18, 1983, (Materials Research Society, Pittsburgh, Pennsylvania, 1983), p. 17.

18. Wolfsberg, K., A. E. Ogard, and D. T. Vaniman, Compilers, "Research and Development Related to the Nevada Nuclear Waste Storage Investigations; January 1 - March 31, 1983," Los Alamos National Laboratory report LA-9793-PR (1983). 
1. Bish, D. L., and R. E. Semarge, "Mineralogic Variations in a Silicic Tuff Sequence: Evidence for Diagenetic and Hydrothermal Reactions," Nineteenth Annual Clay Mineral Society Meeting, Hilo, Hawaii (1982).

2. Bish, D. L., D. T. Vaniman, F. M. Byers, Jr., and D. E. Broxton, "Summary of the Mineralogy-Petrology of Tuffs of Yucca Mountain and Secondary-Phase Thermal Stability in Tuffs," Los Alamos National Laboratory report LA-9321-MS (1982).

3. Blacic, J. D., J. Carter, P. M. Halleck, P. Johnson, T. Shankland, R. Andersen, K. Spicochi, and A. Heller, "Effects of Long-Term Exposure of Tuffs to High-Level Nuclear Waste Repository Conditions: Preliminary Report," Los Alamos National Laboratory report LA-9174-PR (1982).

4. Broxton, D. E., D. T. Vaniman, F. A. Caporuscio, and G. H. Heiken, "Detailed Petrographic Descriptions and Microprobe Data for Drill Holes USW-G2 and UE25b-1H, Yucca Mountain, Nevada," Los Alamos National Laboratory report LA-9324-MS (1982).

5. Caporuscio, F. A., D. T. Vaniman, D. L. Bish, D. E. Broxton, B. H. Arney, G. H. Heiken, M. Byers, Jr., R. C. Gooley, and R. E. Semarge, "Petrologic Studies of Drill Cores USW-G2 and UE25b-1H, Yucca Mountain, Nevada," Los Alamos National Laboratory report LA-9255-MS (1982).

6. Crowe, B. M., M. E. Johnson, and R. J. Beckman, "Calculation of the Probability of Volcanic Disruption of a High-Level Radioactive Waste Repository Within Southern Nevada, USA," Radioactive Waste Management of Nuclear Fuel Cycle 3, 167-190 (1982).

7. Crowe, B. M., D. T. Vaniman, F. V. Perry, R. Amos, and S. Self, “Aspects of Possible Magmatic Disruption of a High-Level Radioactive Waste Repository in Southern Nevada," Los Alamos National Laboratory report LA-9326-MS (1982).

8. Daniels, W. R., Editor, "Summary Report on the Geochemistry of Yucca Mountain and Environs," Los Alamos National Laboratory report LA-9328-MS (1982).

9. Daniels, W. R., K. Wolfsberg, D. T. Vaniman, and B. R. Erdal, Editors, "Research and Development Related to the Nevada Nuclear Waste Storage Investigations, January 1 March 31, 1982," Los Alamos National Laboratory report LA-9327-PR (1982).

10. Erdal, B. R., “Geology of Waste Management," Los Alamos National Laboratory annual report LALP 82-30 (1982).

11. Erdal, B. R., R. S. Rundberg, W. R. Daniels, K. Wolfsberg, A. M. Friedman, S. Fried, and J. Hines, "Nuclide Migration Field Experiments in Tuff, G-Tunnel, Nevada Test Site," in Scientific Basis for Nuclear Waste Management 6 207-216 (1982). 
12. Nelson, D. C., T. J. Merson, P. L. McGuire, and W. L. Sibbitt, "Conceptual Design Report, Exploratory Shaft-Phase I. Nevada Nuclear Waste Storage Investigations," Los Alamos National Laboratory report LA-9179-MS (1982).

13. Norris, A. E., R. D. Aguilar, B. P. Bayhurst, D. L. Bish, M. R. Cisneros, W. R. Daniels, J. Duffy, R. D. Golding, S. L. Jensen, S. D. Knight, F. O. Lawrence, S. Maestas, J. Mitchell, P. Q. Oliver, N. A. Raybold, R. S. Rundberg, G. M. Thompson, N. Treher, B. J. Travis, G. R. Walter, R. G. Warren, and K. Wolfsberg, "Geochemistry Studies Pertaining to the G-Tunnel Radionuclide Migration Field Experiment," Los Alamos National Laboratory report LA-9332-MS (1982).

14. Rundberg, R. S., J. L. Thompson, S. Maestas, and S. V. Topp, "Radionuclide Migration: Laboratory Experiments with Isolated Fractures," in Annual Meeting of the Materials Research Society in Boston Massachusetts, November 15, 1981, 239-348 (1982).

15. Smyth, J. R., "Zeolite Stability Constraints on Radioactive Waste Isolation in Zeolite-Bearing Volcanic Rocks," Journal of Geology 90, 195-201 (1982).

16. Treher, E. N., and N. A. Raybold, "The Elution of Radionuclides through Columns of Crushed Rock from the Nevada Test Site," Los Alamos National Laboratory report LA-9329-MS (1982).

17. Vaniman, D. T., B. M. Crowe, and E. S. Gladney, "Petrology and Geochemistry of Hawaiite Lavas from Crater Flat, Nevada," Contributions to Mineralogy and Petrology 80, 341-357 (1982).

18. Vaniman, D. T., D. L. Bish, R. C. Gooley, and J. Blacic, "Effects of Long-Term Exposure of Tuffs to Simulated High-Level Nuclear Waste Repository Conditions, II:

Investigations of Possible Petrologic and Mineralogic Changes Under High-Level Nuclear Waste Repository Conditions," Los Alamos National Laboratory report LA-9330-MS (1982).

19. Walter, G. R., "Theoretical and Experimental Determination of Matrix Diffusion and Related Solute Transport Properties of Fractured Tuffs from the Nevada Test Site," Los Alamos National Laboratory report LA-9471-MS (1982).

20. Wolfsberg, K., W. R. Daniels, B. R. Erdal, and D. T. Vaniman, Compilers, "Research and Development Related to the Nevada Nuclear Waste Storage Investigations, April 1 - June 30, 1982," Los Alamos National Laboratory report LA-9484-PR (1982).

21. Wolfsberg, K., W. R. Daniels, D. T. Vaniman, and B. R. Erdal, Editors, "Research and Development Related to the Nevada Nuclear Waste Storage Investigations, October 1 December 31, 1982," Los Alamos National Laboratory report LA-9225-PR (1982). 
1. Bish, D. L., "Detailed Mineralogical Characterization of the Bullfrog and Tram Members in USW-G1, with Emphasis on Clay Mineralogy," Los Alamos National Laboratory report LA-9021-MS (1981).

2. Bish, D. L., F. A. Caporuscio, J. F. Copp, B. M. Crowe, J. D. Purson, J. R. Smyth, and G. Warren, "Preliminary Stratigraphic and Petrologic Characterization of Core Samples from USW-G1, Yucca Mountain, Nevada," Los Alamos National Laboratory report LA-8840-MS (1981).

3. Blacic, J. D., "Importance of Creep Failure of Hard Rock in the Near Field of a Nuclear Waste Repository," in Proceedings of the International Atomic Energy Agency in Seattle, Workshop on Near-Field Phenomena in Geologic Repositories for Radioactive Waste, Seattle, Washington, August 31 -September 3, 1981, (International Atomic Energy Agency, Vienna, Austria 1981), pp. 121-132.

4. Carroll, P. R., F. A. Caporuscio, and D. L. Bish, "Further Description of the Petrology of the Topopah Spring Member of the Paintbrush Tuff in Drill Holes UE25a-1 and USW-G1, and of the Lithic-Rich Tuff in USW-G1, Yucca Mountain Nevada," Los Alamos National Laboratory report LA-9000-MS (1981).

5. Erdal, B. R., and K. Wolfsberg, Editors, "Research and Development Related to the Nevada Nuclear Waste Storage Investigations, January 1 - March 31, 1981," Los Alamos National Laboratory report LA-8847-PR (1981).

6. Erdal, B. R., K. Wolfsberg, J. K. Johnstone, K. L. Erickson, A. M. Friedman, S. Fried, and J. Hines, "Nuclide Migration Field Experiments--Program Plan," Los Alamos National Laboratory report LA-8487-PR (1981).

7. Erdal, B. R., W. R. Daniels, D. T. Vaniman, and K. Wolfsberg, Editors, "Research and Development Related to the Nevada Nuclear Waste Storage Investigations, April 1 - June 30, 1981," Los Alamos National Laboratory report LA-8959-PR (1981).

8. Erdal, B. R., W. R. Daniels, D. T. Vaniman, and K. Wolfsberg, Editors, "Research and Development Related to the Nevada Nuclear Waste Storage Investigations, July 1 September 30, 1981," Los Alamos National Laboratory report LA-9095-PR (1981).

9. Smyth, J. R., and F. A. Caporuscio, "Review of the Thermal Stability and Cation Exchange Properties of the Zeolite Minerals Clinoptilolite, Mordenite, and Analcime: Applications to Radioactive Waste Isolation in Silicic Tuff," Los Alamos National Laboratory report LA-8841-MS (1981).

10. Vaniman, D. T., and B. M. Crowe, "Geology and Petrology of the Basalts of Crater Flat: Applications to Volcanic Risk Assessment for the Nevada Nuclear Waste Storage Investigations," Los Alamos Scientific Laboratory report LA-8845-MS (1981). 
11. Vine, E. N., B. P. Bayhurst, W. R. Daniels, S. J. DeVilliers, B. R. Erdal, F. O. Lawrence, and K. Wolfsberg, "Radionuclide Transport and Retardation in Tuff," Scientific Basis for Nuclear Waste Management 3, 483-490 (1981).

12. Wolfsberg, K., and B. R. Erdal, Editors, "Research and Development Related to the Nevada Nuclear Waste Storage Investigations, October 1 - December 31, 1980," Los Alamos National Laboratory report LA-8739-PR (1981).

13. Wolfsberg, K., B. R. Erdal, and B. M. Crowe, Editors, "Research and Development Related to the Nevada Nuclear Waste Storage Investigations, July 1 - September 30, 1980," Los Alamos Scientific Laboratory report LA-8612-PR (1981).

14. Wolfsberg, K., R. D. Aguilar, B. P. Bayhurst, W. R. Daniels, S. J. DeVilliers, B. R. Erdal, F. O. Lawrence, S. Maestas, A. J. Mitchell, P. Q. Oliver, N. A. Raybold, R. S. Rundberg, L. Thompson, and E. N. Vine, "Sorption-Desorption Studies on Tuff. III. A Continuation of Studies with Samples from Jackass Flats and Yucca Mountain, Nevada," Los Alamos National Laboratory report LA-8747-MS (1981). 
1. Crowe, B. M., "Preliminary Assessment of the Risk of Volcanism at a Proposed Nuclear Waste Repository in the Southern Great Basin," US Geological Survey Open-File Report 80-375 (1980).

2. Crowe, B. M., Editor, "Research and Development Related to the Nevada Nuclear Waste Storage, Investigations, October 1 - December 31, 1979," Los Alamos Scientific Laboratory report LA-8309-PR (1980).

3. Crowe, B. M., and K. Wolfsberg, Editors, "Research and Development Related to the Nevada Nuclear Waste Storage Investigations, January 1 - March 31, 1979," Los Alamos Scientific Laboratory report LA-8419-PR (1980).

4. Erdal, B. R., B. P. Bayhurst, B. M. Crowe, W. R. Daniels, D. C. Hoffman, F. O. Lawrence, J. R. Smyth, J. L. Thompson, and K. Wolfsberg, "Laboratory Studies of Radionuclide Transport in Geologic Media," in Proceedings of the IAEA/OFCD Symposium on the Underground Disposal of Radioactive Wastes, Volume II, (International Atomic Energy Agency Vienna, Austria, 1980) Report IAEA-SM-243/37, pp. 367-382.

5. Erdal, B. R., B. P. Bayhurst, W. R. Daniels, S. J. DeVilliers, F. O. Lawrence, L. · Thompson, E. N. Vine, and K. Wolfsberg, "Parameters Affecting Radionuclide Migration in Argillaceous Media," Use of Argillaceous Materials for the Isolation of Radioactive Waste, Proceedings of the NEA Workshop, Paris, France; September 10-12, 1979, 55-66 (1980).

6. Erdal, B. R., B. P. Bayhurst, W. R. Daniels, S. J. DeVilliers, G. H. Heiken, F. O. Lawrence, M. L. Sykes, J. R. Smyth, J. L. Thompson, E. N. Vine, and K. Wolfsberg, "Parameters Affecting Radionuclide Migration in Geologic Media," Scientific Basis for Nuclear Waste Management 2, 609-616 (1980).

7. Smyth, J. R., J. L. Thompson, and K. Wolfsberg, "Microautoradiographic Studies of the Sorption of U and Am on Natural Rock Samples," Radioactive Waste Management 1 , 13-24 (1980).

8. Vine, E. N., R. D. Aguilar, B. P. Bayhurst, W. R. Daniels, S. J. DeVilliers, B. R. Erdal, F. O. Lawrence, S. Maestas, P. Q. Oliver, J. L. Thompson, and K. Wolfsberg, "Sorption-Desorption Studies on Tuff. II. A Continuation of Studies With Samples from Jackass Flats, Nevada, and Initial Studies With Samples from Yucca Mountain, Nevada," Los Alamos Scientific Laboratory report LA-8110-MS (1980).

9. Wolfsberg, K., B. R. Erdal, and J. R. Smyth, Editors, "Research and Development Related to the Nevada Nuclear Waste Storage Investigations, April 1 - June 30, 1985," Los Alamos Scientific Laboratory report LA-8471-PR (1980). 
1. Crowe, B. M., Compiler, "Research and Development Related to the Nevada Nuclear Waste Storage Investigations, January 1 - March 31, 1979," Los Alamos Scientific Laboratory report LA-7900-PR (1979).

2. Crowe, B. M., "Major-Element Geochemistry of the Silent Canyon-Black Mountain Peralkaline Volcanic Centers, Northwestern Nevada Test Site: Applications to an Assessment of Renewed Volcanism," US Geological Survey Open-File Report 79-926, (1979).

3. Crowe, B. M., Editor, "Research and Development Related to the Nevada Nuclear Waste Storage Investigations, July 1 - September 30, 1979," Los Alamos Scientific Laboratory report LA-8152-PR (1979).

4. Erdal, B. R., R. D. Aguilar, B. P. Bayhurst, P. Q. Oliver, and K. Wolfsberg, "Sorption-Desorption Studies on Argillite. I. Initial Studies of Strontium, Technetium. Cesium, Barium, Cerium, Europium, Uranium, Plutonium, and Americium," Los Alamos Scientific Laboratory report LA-7455-MS (1979).

5. Erdal, B. R., W. R. Daniels, D. C. Hoffman, F. O. Lawrence, and K. Wolfsberg, "Sorption and Migration of Radionuclides in Geologic Media," in Scientific Basis for Nuclear Waste Management 1, 432-426 (1979).

6. Erdal, B. R., R. D. Aguilar, B. P. Bayhurst, W. R. Daniels, C. J. Duffy, F. O. Lawrence, S. Maestas, P. Q. Oliver, and K. Wolfsberg, "Sorption-Desorption Studies on Granite. I. Initial Studies of Strontium, Technetium, Cesium, Barium, Cerium, Europium, Uranium, Plutonium, and Americium," Los Alamos Scientific Laboratory report LA-7456-MS (1979).

7. Heiken, G. H., and M. L. Bevier, "Petrology of Tuff Units from the J-13 Drill Site, Jackass Flats, Nevada," Los Alamos Scientific Laboratory report LA-7563-MS (1979).

8. Smyth, J. R., B. M. Crowe, P. M. Halleck, and A. W. Reed, "A Preliminary Evaluation of the Radioactive Waste Isolation Potential of the Alluvium-Filled Valleys of the Great Basin," Los Alamos Scientific Laboratory report LA-7962-MS (1979).

9. Sykes, M. L., G. H. Heiken, and J. R. Smyth, "Mineralogy and Petrology of Tuff Units From the UE25a-1 Drill Site, Yucca Mountain, Nevada," Los Alamos Scientific Laboratory report LA-8139-MS (1979).

10. Thompson, J. L., and K. Wolfsberg, "Applicability of Microautoradiography to Sorption Studies," Los Alamos Scientific Laboratory report LA-7609-MS (1979).

11. Wolfsberg, K., Compiler, "Research and Development Related to the NTS Terminal Waste Storage Project, October 1 - December 31, 1978," Los Alamos Scientific Laboratory report LA-7647-PR (1979). 
12. Wolfsberg, K., Editor, "Research and Development Related to the Nevada Nuclear Waste Storage Investigations, April 1 - June 31, 1979," Los Alamos Scientific Laboratory report LA-7974-PR (1979).

13. Wolfsberg, K., B.P. Bayhurst, B.M. Crowe, W.R. Daniels, B.R. Erdal, F.O. Lawrence, E. Norris, and J. R. Smyth, "Sorption-Desorption Studies on Tuff. I. Initial Studies with Samples from the J-13 Drill Site, Jackass Flats, Nevada," Los Alamos Scientific Laboratory report LA-7480-MS (1979). 


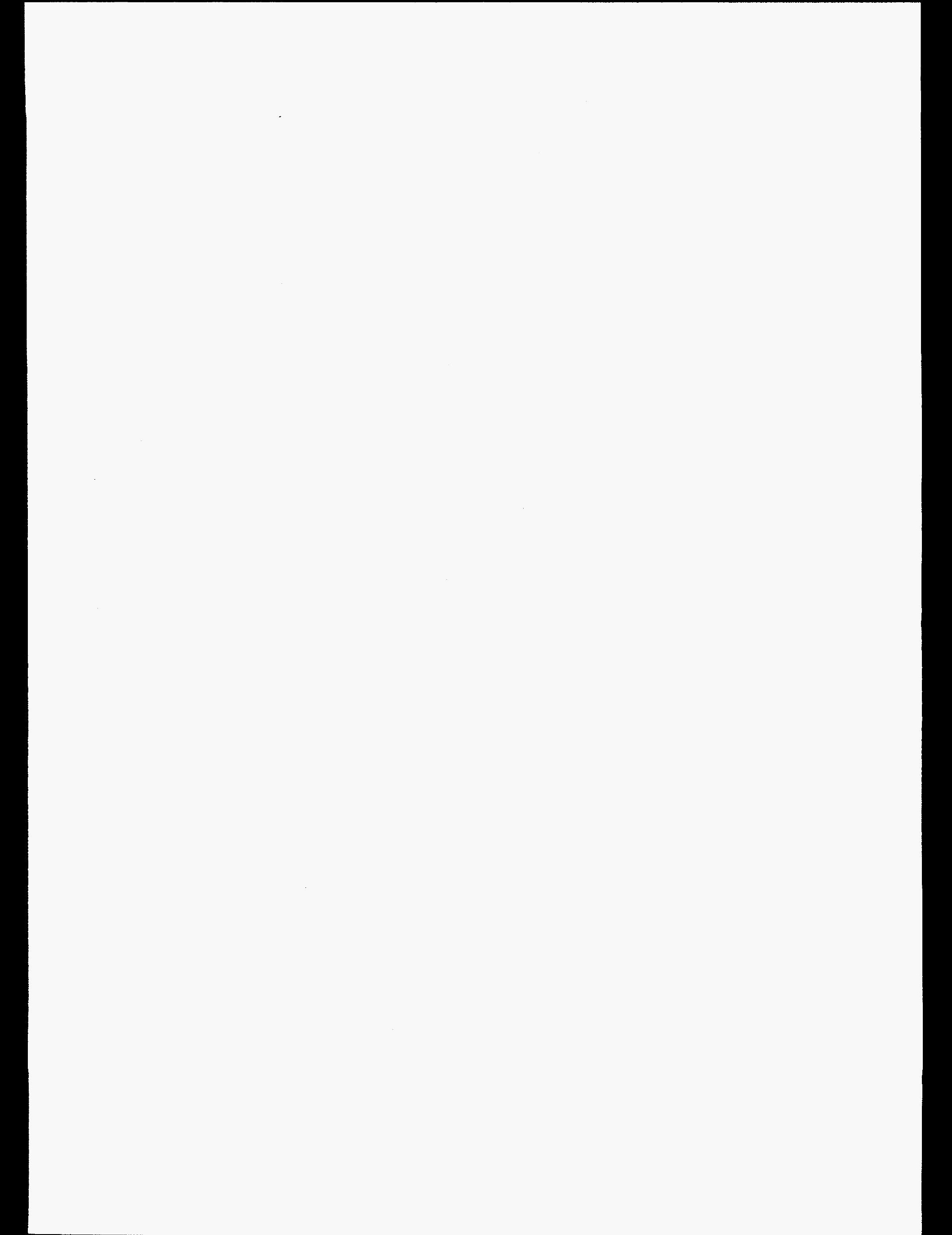




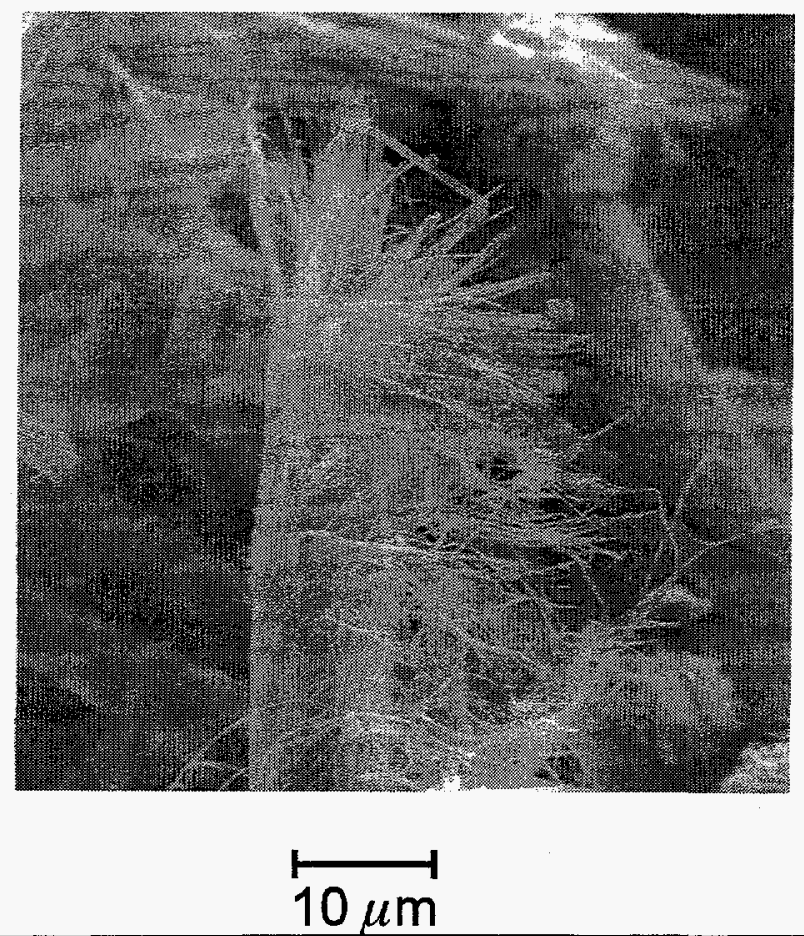

SEM photo of erionite USW UZ-14, $415.7 \mathrm{~m}$

\section{Mineralogy/Petrology/Geology}

1. Bish, D.L. "Quantitative X-ray Diffraction Analysis of Soils," in Quantitative Methods in Soil Mineralogy, J.E. Amonette and L.W. Zelazny, Eds. (Soil Science Society of America, Madison, Wisconsin, 1994), pp. 267-295.

2. Bish, D.L., "Studies of Clays and Clay Minerals Using X-ray Powder Diffraction and the Rietveld Method," in Computer Applications to X-ray Powder Diffraction Analysis of Clay Minerals, CMS Workshop Lectures 5, R.C. Reynolds, Jr. and J.R. Walker, Eds. (Clay Minerals Society, Boulder, Colorado, 1993), pp. 79-122.

3. Bish, D.L., "Thermal Stability of Zeolitic Tuff from Yucca Mountain, Nevada," in High Level Radioactive Waste Management: Proceedings of the First Annual International Topical Meeting April 8-12, 1990 (American Nuclear Society, La Grange Park, Illinois, 1990), pp. 596-602.

4. Bish, D.L., "Long-Term Thermal Stability of Clinoptilolite: The Development of a 'B'Phase," European Journal of Mineralogy 2, 771-777 (1990).

5. Bish, D.L., "Evaluation of Past and Future Alterations in Tuff at Yucca Mountain, Nevada, Based on the Clay Mineralogy of Drill Cores USE G-1, G-2, and G-3," Los Alamos National Laboratory report LA-10667-MS (1989). 
6. Bish, D.L., "Effects of Composition on the Dehydration Behavior of Clinoptilolite and Heulandite," in Occurrence, Properties and Utilization of Natural Zeolites, D. Kallo and H.S. Sherry, Eds. (Akademiai Kiado, Budapest, 1988), pp. 565-576.

7. Bish, D.L., "Problems and Solutions In Quantitative Analysis of Complex Mixtures by X-ray Powder Diffraction," Advances In X-ray Analysis 31, 295-308 (1987).

8. Bish, D.L., “Review of Natural Zeolites," Journal of Sedimentary Petrology 57, 390-391 (1987).

9. Bish, D.L., "Smectite Dehydration and Stability: Applications to Radioactive Waste Isolation at Yucca Mountain, Nevada," Los Alamos National Laboratory report LA-11023-MS (1987).

10. Bish, D.L., "Thermogravimetric Analysis of Minerals," in Workshop on Advanced Methods of Thermal Analysis, (Clay Minerals Society, Socorro, New Mexico, 1987).

11. Bish, D.L., "The Clay Mineralogy of Drill Cores USW-G1, G2, and G3: Applications to Past and Future Alterations in Tuff," Los Alamos National Laboratory report LA-10667MS (1985).

12. Bish, D.L., "Effects of Exchangeable Cation Composition on the Thermal Expansion/Contraction Behavior of Clinoptilolite," Clays and Clay Minerals 32, 444-452 (1984).

13. Bish, D.L., "Detailed Mineralogical Characterization of the Bullfrog and Tram Members in USW-G1, with Emphasis on Clay Mineralogy," Los Alamos National Laboratory report LA-9021-MS (1981).

14. Bish, D.L., and J. Aronson, "Paleogeothermal and Paleohydrologic Conditions in Silicic Tuff from Yucca Mountain, Nevada," Clays and Clay Minerals 41, 148-161 (1993).

15. Bish, D.L., and S.J. Chipera, "Detection of Trace Amounts of Erionite Using X-ray Powder Diffraction: Erionite in Tuffs of Yucca Mountain, Nevada, and Central Turkey," Clay and Clay Minerals 39, 437-445 (1991).

16. Bish, D.L., and S.J. Chipera, "Revised Mineralogic Summary of Yucca Mountain, Nevada," Los Alamos National Laboratory report LA-11497-MS (1989).

17. Bish D.L. and S.J. Chipera, "Problems and Solutions in Quantitative Analysis of Complex Mixtures by X-ray Powder Diffraction," Advances in X-ray Analysis 31, 295-308 (1987).

18. Bish, D.L., and S.J. Chipera, "Mineralogy of Drill Holes J-13, UE-25a\#l, and USW G-1 at Yucca Mountain, Nevada," Los Alamos National Laboratory report LA-10764-MS (1986).

19. Bish, D.L., and G.D. Guthrie, Jr., "Mineralogy of Clay and Zeolite Dusts (Exclusive of 1:1 Layer Silicates)" in Health Effects of Mineral Dusts, Reviews in Mineralogy 28, G.D. Guthrie, Jr., and B.T. Mossman, Eds. (Mineralogical Society of America, Washington, D. C., 1993) pp. 139-184. 
20. Bish, D.L., and S.A. Howard, "Quantitative Phase Analysis Using the Rietveld Technique," Journal of Applied Crystallography 32, 86-91 (1988).

21. Bish, D.L., and J.E. Post Eds., "Modern Powder Diffraction," Mineralogical Society of America Reviews in Mineralogy 20, 369 pp. (1989).

22. Bish, D.L., and J.E. Post, "Thermal Behavior of Complex, Tunnel-Structure Manganese Oxides," American Mineralogist 74, 177-186 (1989).

23. Bish, D.L., and R.E. Semarge, "Mineralogic Variations in a Silicic Tuff Sequence:

Evidence for Diagenetic and Hydrothermal Reactions," Nineteenth Annual Clay Mineral Society Meeting, Hilo, Hawaii, (1982).

24. Bish, D.L., and J.E. Post, "Quantitative Mineralogical Analysis Using the Rietveld FullPattern Fitting Method," in American Mineralogist 78, 932-940 (1993).

25. Bish, D.L., and D.T. Vaniman, "Mineralogic Summary of Yucca Mountain, Nevada," Los Alamos National Laboratory report LA-10543-MS (1985).

26. Bish, D.L., A.E. Ogard, D.T. Vaniman, and L. Benson, "Mineralogy-Petrology and Groundwater Geochemistry of Yucca Mountain Tuffs," in Scientific Basis for Nuclear Waste Management VII, Materials Research Society Symposia Proceedings 26, G.L. McVay, Ed. (New York, Elsevier Science Pub. Co., 1984), pp. 283-291.

27. Bish, D.L., D.T. Vaniman, R.S. Rundberg, K. Wolfsberg, W.R. Daniels, and D.E. Broxton, "Natural Sorptive Barriers in Yucca Mountain, Nevada, for Long-Term Isolation of High-Level Waste," in Proceedings of an International Conference on Radioactive Waste Management held by the international Atomic Energy Agency in Seattle, Washington, May 16-20, 1983, (International Energy Agency, Vienna, Austria, 1983), pp. 415-432.

28. Bish, D.L., D.T. Vaniman, F.M. Byers, Jr., and D.E. Broxton, "Summary of the Mineralogy-Petrology of Tuffs of Yucca Mountain and Secondary-Phase Thermal Stability in Tuffs," Los Alamos National Laboratory report LA-9321-MS (1982).

29. Bish, D.L., F.A. Caporuscio, J.F. Copp, B.M. Crowe, J.D. Purson, J.R. Smyth, and Warren, "Preliminary Stratigraphic and Petrologic Characterization of Core Samples from USW-G1, Yucca Mountain, Nevada," Los Alamos National Laboratory report LA-8840-MS (1981).

30. Blacic J.D., "Hydration Swelling Effects on Time-Dependent Deformation of Zeolitized Tuff," Journal of Geophysical Research 98, 15,909-15,917 (1993).

31. Blacic, J.D., "Importance of Creep Failure of Hard Rock in the Near Field of a Nuclear Waste Repository," in Proceedings of an International Conference on Radioactive Waste Management held by the international Atomic Energy Agency in Seattle, Washington, August 31 - September 3, 1981, (International Atomic Energy Agency, Vienna, Austria, 1981), 121-132. 
32. Blacic, J.D., and R. Andersen, "Methodology for Determining the Time Dependent Mechanical Properties of Tuff Subjected to Near-Field Repository Conditions," Los Alamos National Laboratory report LA-9322-MS (1983).

33. Blacic, J.D., D.T. Vaniman, D.L. Bish, C.J. Duffy, and R.C. Gooley, "Effects of Long-Term Exposure of Tuffs to High-Level Nuclear Waste Repository Conditions: Final Report," Los Alamos National Laboratory report LA-9330-MS (1986).

34. Blacic, J.D., J. Carter, P.M. Halleck, P. Johnson, T. Shankland, R. Andersen, K. Spicochi, and A. Heller, "Effects of Long-Term Exposure of Tuffs to High-Level Nuclear Waste Repository Conditions: Preliminary Report," Los Alamos National Laboratory report LA-9174-PR (1982).

35. Bolivar, S.L., D.E. Broxton, D.L. Bish, F.M. Byers, B.A. Carlos, S.S. Levy, D.T. Vaniman, and S.J. Chipera, "Mineralogy-Petrology Studies And Natural Barriers at Yucca Mountain, Nevada," in Procedures of the Topical Meeting on Nuclear Waste Isolation in the Unsaturated Zone: FOCUS '89 (American Nuclear Society, La Grange Park, Illinois, 1989), pp. 125-133.

36. Broxton, D.E., "Chemical Changes Associated with Zeolitization on the Tuffaceous Beds of Calico Hills at Yucca Mountain, Nevada," in Water-Rock Interaction, Proceedings of the 7th International Symposium on Water-Rock Interaction, WRI-7, Park City Utah, USA, 13-18 July, (A.A. Balkema, Rotterdam and Brookfield, Capetown South Africa, 1992), pp. 699-703.

37. Broxton D.E., "Clinoptilolite Compositions in Diagenetically-Altered Tuffs at a Potential Nuclear Waste Repository, Yucca Mountain, Nevada," in The Technology of High Level Nuclear Waste Disposal, pp. 179-194 (1987).

38. Broxton, D.E., and B.A. Carlos, "Zeolitic Alteration and Fracture Fillings in Silicic Tuffs at a Potential Nuclear Waste Repository, Yucca Mountain, Nevada, USA," Proceedings of the Fifth International Symposium on Water-Rock Interaction, Reykjavik, Iceland, August 8-17, pp. 88-91 (1986).

39. Broxton, D.E, S.J. Chipera, F.M. Byers, Jr., L.A. Rautman, "Geological Evaluation of Six Nonwelded Tuff Sites in the Vicinity of Yucca Mountain, Nevada, for a Surface-based Test Facility for the Yucca Mountain Project," Los Alamos National Laboratory report LA-12542-MS (1993).

40. Broxton, D.E., R.G. Warren, F.M. Byers, and R.B. Scott, "Chemical and Mineralogic Trends Within the Timber Mountain - Oasis Valley Caldera Complex, Nevada: Evidence for Multiple Cycles of Chemical Evolution in a Long-Lived Magma System," Journal of Geophysical Research 94, 5961-5985 (1989).

41. Broxton, D.E., F.M. Byers, Jr., and R.G. Warren, "Petrography of Phenocryst Chemistry of Volcanic Units at Yucca Mountain: A Comparison of Outcrop and Drill Hole Samples," Los Alamos National Laboratory report LA-11503-MS (1989). 
42. Broxton, D.E., D.L. Bish, and R.G. Warren, "Distribution and Chemistry of Diagenetic Minerals, Yucca Mountain, Nye County, Nevada," Clays and Clay Minerals 35, 89-110 (1987).

43. Broxton, D.E., R.G. Warren, R.C. Hagan, and G. Luedemann, "Chemistry of Diagenetically Altered Tuffs at a Potential Nuclear Waste Repository, Yucca Mountain, Nye County, Nevada," Los Alamos National Laboratory report LA-10802-MS (1986).

44. Broxton, D.E., D.T. Vaniman, F.A. Caporuscio, and G.H. Heiken, "Detailed Petrographic Descriptions and Microprobe Data for Drill Holes USW-G2 and UE25b-lH, Yucca Mountain, Nevada," Los Alamos National Laboratory report LA-9324-MS (1982).

45. Byers, F.M. Jr., "Petrochemical Variation of Topopah Spring Tuff Matrix with Depth (Stratigraphic Level), Drill Hole USW G-4, Yucca Mountain, Nevada," Los Alamos National Laboratory report LA-10561-MS (1985).

46. Byers, F.M. Jr., and R.G. Warren, "Revised Volcanic Stratigraphy of Drill Hole J-13, Fortymile Wash, Nevada, Based on Petrographic Modes and the Chemistry of Phenocrysts," Los Alamos National Laboratory report LA-9652-MS (1983).

47. Campbell, K., "Statistical Guidelines for Planning a Limited Drilling Program," Los Alamos National Laboratory report LA-11293-MS (1988).

48. Campbell, K., D.E. Broxton, and J. Spaw, "Status of Image Analysis Methods to Delineate Stratigraphic Position in the Topopah Spring Member of the Paintbrush Tuff, Yucca Mountain, Nye County, Nevada," Los Alamos National Laboratory report LA11694-MS (1989).

49. Caporuscio, F.A., and D.T. Vaniman, "Iron and Manganese in Oxide Minerals and in Glasses: Preliminary Consideration of Eh Buffering Potential at Yucca Mountain, Nevada," Los Alamos National Laboratory report LA-10369-MS (1985).

50. Caporuscio, F.A., R.G. Warren, and D.E. Broxton, "Detailed Petrographic Descriptions and Microprobe Data for Tertiary Silicic Volcanic Rocks in Drill Hole USW G-1, Yucca Mountain, Nevada," Los Alamos National Laboratory report LA-9323-MS (1985).

51. Caporuscio, F.A., D.T. Vaniman, D.L. Bish, D.E. Broxton, B.H. Arney, G.H. Heiken, F.M. Byers, Jr., R.C. Gooley, and R.E. Semarge, "Petrologic Studies of Drill Cores USW-G2 and UE25b-1H, Yucca Mountain, Nevada," Los Alamos National Laboratory report LA-9255-MS (1982).

52. Carey J.W., and D.L. Bish, "Enthalpy of Hydration of Cation-Exchanged Clinoptilolite," American Geophysical Union 75 (44), 698 (1994).

53. Carlos, B.A., "Field Guide to Fracture-lining Minerals at Yucca Mountain, Nevada," Los Alamos National Laboratory report LA-12803-MS (1994).

54. Carlos, B.A., "Fracture-Coating Minerals in the Topopah Spring Member and Upper Tuff of Calico Hills from Drill Hole J-13," Los Alamos National Laboratory report LA11504-MS (1989).

55. Carlos, B.A., "Minerals in Fractures of the Saturated Zone from Drill Core USW G-4, Yucca Mountain, Nye County, Nevada," Los Alamos National Laboratory report LA-10927-MS (1987). 
56. Carlos, B.A., "Occurrence of Fracture-Lining Manganese Minerals in Silicic Tuffs, Yucca Mountain, Nevada, USA," Proceedings of Fifth International Symposium on Water-Rock Interaction, Reykjavik, Iceland, August 8-17, pp. 96-99 (1986).

57. Carlos, B.A., "Minerals in Fractures of the Unsaturated Zone from Drill Core USW G-4, Yucca Mountain, Nye County, Nevada," Los Alamos National Laboratory report LA-10415-MS (1985).

58. Carlos, B.A., D.L. Bish, and S.J. Chipera, "Distribution of Fracture-lining Minerals at Yucca Mountain," in U. S. Geological Survey Committee for the Advancement of Science in the Yucca Mountain Project Symposium of Fracture, Hydrology and Yucca Mountain, U. S. Geological Survey Open-File Report 91-125 (1991) pp. 18-19.

59. Carlos, B.A., D.L. Bish, and S.J. Chipera, "Manganese-Oxide Minerals in Fractures of the Crater Flat Tuff in Drill Core USW-G-4," Los Alamos National Laboratory report LA-11787-MS (1990).

60. Carlos, B.A., D.L. Bish, S.J. Chipera, and S. Craven, "Fracture-Lining Manganese Oxide Minerals in a Silicic Tuff," in Chemical Geology 107, 47-69 (1993).

61. Carlos, B.A., D.L. Bish, and S.J. Chipera, "Fracture-Lining Minerals in the Lower Topopah Spring Tuff at Yucca Mountain," in High Level Radioactive Waste Management: Proceedings of the Second Annual International Conference, Las Vegas, Nevada, April 28-May 3, 1991 (American Nuclear Society, La Grange Park, Illinois, 1991), pp. 486-493.

62. Carr, M.D., S.J. Waddell, G.S. Vick, J.M. Stock, S.A. Monsen, A.G. Harris, B.W. Cork, and F.M. Byers, Jr., "Geology of Drill Hole UE-25p\#l: A Test Hole into Pre-Tertiary Rocks Near Yucca Mountain, Southern Nevada," US Department of the Interior/Geological Survey Report USGS-OF-86-175 (1986).

63. Carroll, P.R., F.A. Caporuscio, and D.L. Bish, "Further Description of the Petrology of the Topopah Spring Member of the Paintbrush Tuff in Drill Holes UE25a-1 and USW-G1, and of the Lithic-Rich Tuff in USW-G1, Yucca Mountain Nevada," Los Alamos National Laboratory report LA-9000-MS (1981).

64. Chipera, S.J., and D.L. Bish, "The Occurrence and Distribution of Erionite at Yucca Mountain, Nevada," Los Alamos National Laboratory report LA-11663-MS (1989).

65. Chipera, S.J., and D.L. Bish, "Mineralogy of Drill Hole UE-25p\#1 at Yucca Mountain, Nevada," Los Alamos National Laboratory report LA-11292-MS, (1988).

66. Chipera, S.J., G.D. Guthrie, Jr., and D.L. Bish, "Preparation and Purification of Mineral Dusts," in Health Effects of Mineral Dusts, Reviews in Mineralogy 28, G.D. Guthrie, Jr., and B.T. Mossman, Eds. (Mineralogical Society of America, Washington, D. C., 1993) pp. $235-250$.

67. Cowan, D., V. Priest, and S. Levy, "ESR Dating of Quartz from Exile Hill Nevada," Applied Radiation and Isotopes 44, $1035-1039$ (1993).

68. Department of Energy, "Evaluation of the Potentially Adverse Condition Evidence of Extreme Erosion during the Quaternary Period at Yucca Mountain," DOE report YMP/92-41-TPR (1993). 
69. Duffy, C.J., "Preliminary Conceptual Model for Mineral Evolution in Yucca Mountain," Los Alamos National Laboratory report LA-12708-MS (1993).

70. Duffy, C.J., "Kinetics of Silica-Phase Transitions," Los Alamos National Laboratory report LA-12564-MS (1993).

71. Duffy, C.J., "Thermodynamic Model for Analcime," Isotope and Nuclear Chemistry Division Annual Report FY 1983; Los Alamos National Laboratory report LA-10130-PR (1984).

72. Guthrie, G.D. Jr., and B.T. Mossman, Eds., Health Effects of Mineral Dusts, Reviews in Mineralogy 28, (Mineralogical Society of America, Washington, D. C., 1993).

73. Guthrie, G.D., Jr., "Biological Effects of Inhaled Minerals," American Mineralogist 77, pp. 225-243 (1992).

74. Harrington, C.D., and J.W. Whitney, "Scanning Electron Microscope Method for Rock-Varnish Dating," Geology 15, 967-970 (1987).

75. Heiken, G.H., and M.L. Bevier, "Petrology of Tuff Units from the J-13 Drill Site, Jackass Flats, Nevada," Los Alamos Scientific Laboratory report LA-7563-MS (1979).

76. Kranz, R.L., D.L. Bish, and J.D. Blacic, "Hydration and Dehydration Of Zeolitic Tuff from Yucca Mountain Nevada," Geophysical Research Letters 16, 1113-1116 (1989).

77. Levy, S.S., "Surface-Discharging Hydrothermal Systems at Yucca Mountain -- Examining the Evidence," in Scientific Basis for Nuclear Waste Management XVI, C.J. Interrante and R.T. Pabalan, Eds. (Materials Research Society, Pittsburgh , Pennsylvania, 1993), pp. 543-548.

78. Levy, S.S., "Natural Gels in the Yucca Mountain Area, Nevada, USA," in Applied Clay Science 7, 79-85 (1993).

79. Levy, S.S., "Mineralogic Alteration History and Paleohydrology at Yucca Mountain, Nevada," in High Level Radioactive Waste Management: Proceedings of the Second Annual International Conference, Las Vegas, Nevada, April 28-May 3, 1991 (American Nuclear Society, La Grange Park, Illinois, 1991) pp. 477-485.

80. Levy, S.S., "Petrology of Samples from Drillholes USW-H3, H4, H5, Yucca Mountain, Nevada," Los Alamos National Laboratory report LA-9706-MS (1984). 
81. Levy S.S., "Studies of Altered Vitrophyre for the Prediction of Nuclear Waste Repository-Induced Thermal Alteration at Yucca Mountain, Nevada," in Scientific Basis for Nuclear Waste Management VII (New York, Elsevier Science Pub. Co., 1984), pp. 959-966.

82. Levy, S.S., "Studies of Altered Vitrophyre for the Prediction of Nuclear Waste Repository-Induced Thermal Alteration at Yucca Mountain, Nevada," in Proceedings of the Materials Research Society Annual Meeting, Boston, Massachusetts, November 13-18, (Materials Research Society, Pittsburgh, Pennsylvania, 1983), pp. 959-966.

83. Levy, S.S., and J.R. O'Neil, "Moderate-Temperature Zeolitic Alteration in a Cooling Pyroclastic Deposit," Chemical Geology 76, 321-326 (1989).

84. Levy, S.S., and Valentine G.A., "Natural Alteration in the Cooling Topopah Spring Tuff, Yucca Mountain Nevada, as an Analog to a Waste-Repository Hydrothermal Regime," in Proceedings: Site Characterization and Model Validation Focus '93 (American Nuclear Society La Grange Park, Illinois, 1993), pp. 145-149.

85. Levy, S.S., B.A. Carlos, and H. Claassen, "Smectite-Zeolite Fracture Filling Caught in the Act?" American Geophysical Union, San Francisco, California, December 8-12, 321326 (1986).

86. Loeven, C., "A Summary and Discussion of Hydrologic Data from the Calico Hill Nonwelded Hydrogeologic Unit at Yucca Mountain, Nevada," Los Alamos National Laboratory report LA-12376-MS (1993).

87. Moore, L.M., F.M. Byers, and D.E. Broxton, "Statistical Test of Reproducibility and Operator Variance in Thin-Section Modal Analysis of Textures and Phenocrysts in the Topopah Spring Member, Drill Hole USW VH-2, Crater Flat, Nye County, Nevada," Los Alamos National Laboratory report LA-11452-MS (1989).

88. Post, J.E., and D.L. Bish, "Rietveld Refinements of the Coronadite Structure," American Mineralogist 74, 913-917 (1989).

89. Post, J.E., and D.L. Bish, "Rietveld Refinement of the Todorokite Structure," American Mineralogist 73, 861-869 (1988).

90. Reneau, S. "Manganese Accumulation in Rock Varnish in a Desert Piedmont, Mojave Desert, California, and Application to Evaluating Varnish Development," Quaternary Research 40, 309-317 (1993).

91. Reneau, S., R. Raymond, Jr., and C.D. Harrington, "Cation-Ratio Dating of Rock Varnish: Why Does it Work?” Geology 19, 937-940 (1991).

92. Reneau, S., R. Raymond Jr., and C.D. Harrington, "Elemental Relationships in Rock Varnish Stratigraphic Layers, Cima Volcanic Field, California: Implications for Varnish Development and the Interpretation of Varnish Chemistry," American Journal of Science 292, 684-723 (1993). 
93. Roy, D.M., and C.A. Langton, "Studies of Ancient Concrete as Analogs of Cementitious Sealing Materials for a Repository in Tuff," Los Alamos National Laboratory report LA-11527-MS (1989).

94. Scheetz, B.E., and D.M. Roy, "Preliminary Survey of the Stability of Silica-Rich Cementitious Mortars 82-22 and 84-12 with Tuff," Los Alamos National Laboratory report LA-11222-MS (1989).

95. Scheetz, B.E., and D.M. Roy, "Reactivity of a Tuff-Bearing Concrete: CL-40 CON-14," Los Alamos National Laboratory report LA-11532-MS (1989).

96. Smyth, J.R., "Zeolite Stability Constraints on Radioactive Waste Isolation in Zeolite-Bearing Volcanic Rocks," Journal of Geology 90, 195-201 (1982).

97. Smyth, J.R., and F.A. Caporuscio, "Review of the Thermal Stability and Cation Exchange Properties of the Zeolite Minerals Clinoptilolite, Mordenite, and Analcime: Applications to Radioactive Waste Isolation in Silicic Tuff," Los Alamos National Laboratory report LA-8841-MS (1981).

98. Smyth J.R., A.T. Spaid, and D.L. Bish, "Crystal Structures of a Natural and a Csexchanged Clinoptilolite," American Mineralogist 75, 522-528 (1990).

99. Smyth, J.R., B.M. Crowe, P.M. Halleck, and A.W. Reed, "A Preliminary Evaluation of the Radioactive Waste Isolation Potential of the Alluvium-Filled Valleys of the Great Basin," Los Alamos Scientific Laboratory report LA-7962-MS (1979).

100. Stucki, J.W., and D.L. Bish, Eds., "Thermal Analysis in Clay Science," in The Clay Mineral Society Workshop Lectures 3, 192 pp. (1990).

101. Stuckless J.S., Z.E. Peterman, R.M. Forester, J.F. Whelan, D.T. Vaniman, B.D. Marshall, and E.M. Taylor, "Characterization of Fault-Filling Deposits in the Vicinity of Yucca Mountain, Nevada," in WM' 92 Conference Proceedings, Tucson Arizona March 1-5, 929-935 (1992).

102. Sykes, M.L., G.H. Heiken, and J.R. Smyth, "Mineralogy and Petrology of Tuff Units From the UE25a-1 Drill Site, Yucca Mountain, Nevada," Los Alamos Scientific Laboratory report LA-8139-MS (1979).

103. Vaniman, D.T., "Calcite Deposits in Drill Cores USW G-2 and USW GU-3/G-3 at Yucca Mountain, Nevada: Preliminary Report," Los Alamos National Laboratory report LA-12720-MS (1994).

104. Vaniman D.T., S.J. Chipera and D.L. Bish, "Pedogenesis of Siliceous Calcretes at Yucca Mountain, Nevada," Geoderma 63, 1-17 (1994).

105. Vaniman, D.T., "Calcite Deposits in Fractures at Yucca Mountain, Nevada," in High Level Waste Management: Proceedings of the Fourth Annual International Conference, Las Vegas, Nevada, April 26-30, 1993 (American Nuclear Society, La Grange Park, Illinois, 1993), pp. 1935-1939. 
106. Vaniman, D.T., and J.F. Whelan, "Inferences of Paleoenvironment from Petrographic, Chemical and Stable-Isotope Studies of Calcretes and Fracture Calcites," in High Level Radioactive Waste Management: Proceedings of the Fifth Annual International Conference, Las Vegas, Nevada, May 22-26, 1994, (American Nuclear Society, La Grange Park, Illinois, 1994) pp. 2730-2737.

107. Vaniman, D.T., S.J. Chipera, and D.L. Bish, "Pedogenesis of Siliceous Calcretes at Yucca Mountain, Nevada," Geoderma 63, 1-17 (1994).

108. Vaniman, D.T., D.L. Bish, and S.J. Chipera, "Dehydration and Rehydration of a Tuff Vitrophyre," in Journal of Geophysical Research 98, 22,309 - 22,320 (1993).

109. Vaniman, D.T., D.L. Bish, M.H. Ebinger, and S.J. Chipera, "Precipitation of Calcite, Dolomite, Sepiolite, and Silica from Evaporated Carbonate and Tuffaceous Waters of Southern Nevada," in Water-Rock Interaction, Proceedings of the 7th International Symposium on Water-Rock Interaction, WRI-7, Park City Utah, USA, 13-18 July 1992, (A.A. Balkema, Rotterdam and Brookfield, Capetown, South Africa, 1992), pp. 687-692.

110. Vaniman, D.T., D.L. Bish, and S.J. Chipera, "A Preliminary Comparison of Mineral Deposits in Faults near Yucca Mountain, Nevada, with Possible Analogs," Los Alamos National Laboratory report LA-11289-MS (1988).

111. Vaniman, D.T., D.L. Bish, L. Brown, D.E. Broxton, F.M. Byers, B.A. Carlos, S.J. Chipera, S.S. Levy, P. Stringer, and D.T. Vaniman, "Research by ESS Division for Nuclear Waste Storage Investigations: January - June 1985," Los Alamos National Laboratory report LA-10987-PR (1987).

112. Vaniman, D.T., D.L. Bish, D.E. Broxton, F.M. Byers, Jr., G.H. Heiken, B.A. Carlos, Semarge, F.A. Caporuscio, and R.C. Gooley, "Variations in Authigenic Mineralogy and Sorptive Zeolite Abundance at Yucca Mountain, Nevada, Based on Studies of Drill Cores USW GU-3 and G-3," Los Alamos National Laboratory report LA-9707-MS (1984).

113. Vaniman, D.T., D.L. Bish, R.C. Gooley, and J. Blacic, "Effects of Long-Term Exposure of Tuffs to Simulated High-Level Nuclear Waste Repository Conditions, II:

Investigations of Possible Petrologic and Mineralogic Changes Under High-Level Nuclear Waste Repository Conditions," Los Alamos National Laboratory report LA-9330-MS (1982).

114. Warren, R.G., F.M. Byers, Jr., and F.A. Caporuscio, "Petrography and Mineral Chemistry of Units of the Topopah Spring, Calico Hills, and Crater Flat Tuffs, and Older Volcanic Units, with Emphasis on Samples from Drill Holes USW G-1, Yucca Mountain, Nevada Test Site," Los Alamos National Laboratory report LA-10003-MS (1984).

115. Whelan, J.F., D.T. Vaniman, J.S. Stuckless, and R.J. Moscati, "Paleoclimatic and Paleohydrologic Records from Secondary Calcite: Yucca Mountain, Nevada," in High Level Radioactive Waste Management: Proceedings of the Fifth Annual International Conference, Las Vegas, Nevada, May 22-26, 1994 (American Nuclear Society, La Grange Park, Illinois, 1994), pp. 2738-2745. 
116. Whitney, J.W. and Harrington C.D., "Relict Colluvial Boulder Deposits as Paleoclimatic Indicators in the Yucca Mountain Region, Southern Nevada," Geological Society of America Bulletin 105, 1008-1018 (1993).

117. WoldeGabriel, G., D.E. Broxton, D.L. Bish, and S.J. Chipera, "Mineralogy and Clinoptilolite K/Ar Results from Yucca Mountain, Nevada, USA: A Potential High-Level Radioactive Waste Repository Site," Los Alamos National Laboratory report LA-12652MS (1993).

118. WoldeGabriel, G., D.E. Broxton, D.L. Bish, and S.J. Chipera, "Preliminary Assessment of Clinoptilolite K/Ar Results from Yucca Mountain, Nevada: a Potential High-Level Radioactive Waste Repository Site," in Water-Rock Interaction, Proceedings of the 7th International Symposium on Water-Rock Interaction, WRI-7, Park City Utah, USA, July 1992, (A.A. Balkema, Rotterdam and Brookfield, Capetown, South Africa, 1992), pp. 457-461. 



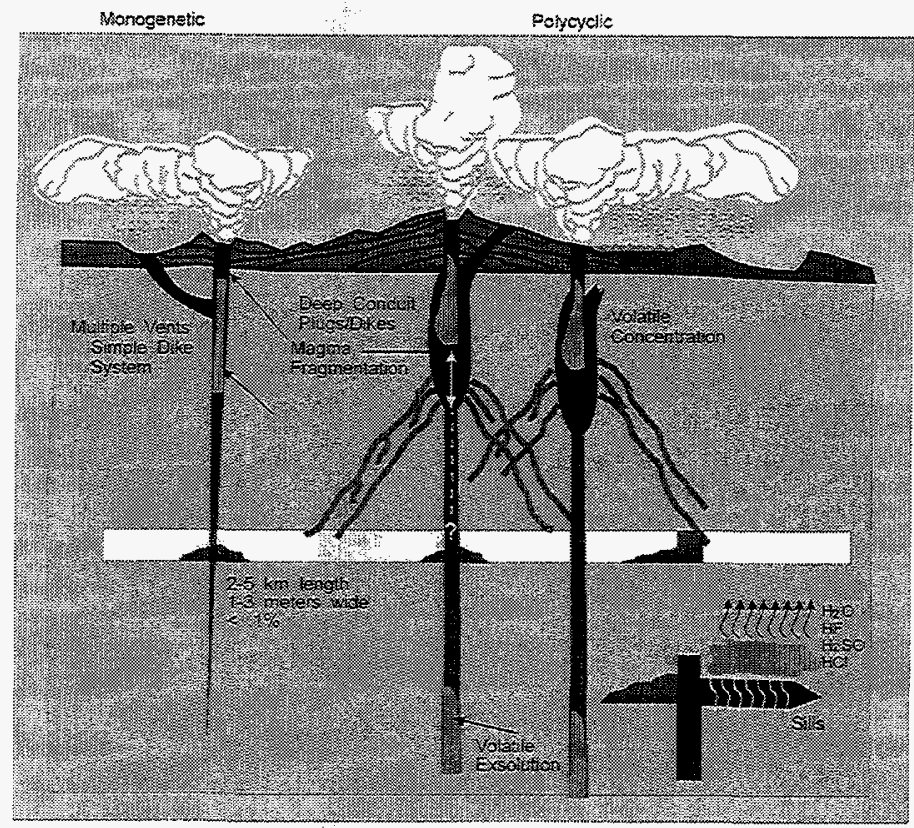

Schematic cross section of a volcanic event penetrating a repository

\section{Volcanism}

1. Carr, W.J., A.M. Rogers, and B.M. Crowe, "Nevada Test Site and Vicinity; Tectonics, Seismicity, and Volcanism of the Southern Great Basin," in US Geological Survey Research in Radioactive Waste Disposal-Fiscal Year 1982, US Geological Survey WaterResources Investigations Report 84-4205, pp. 19-28 (1984).

2. Crowe, B.M., "Basaltic Volcanic Episodes of the Yucca Mountain Region," in High Level Radioactive Waste Management: Proceedings of the First Annual International Topical Meeting April 8-12, 1990 (American Nuclear Society, La Grange Park, Illinois, 1990), pp. 65-73.

3. Crowe, B.M., "Volcanic Hazard Assessment for Disposal of High- Level Radioactive Waste," in Active Tectonics (National Academy Press, Washington, D. C., 1986), pp. 247-260.

4. Crowe, B.M., "Preliminary Assessment of the Risk of Volcanism at a Proposed Nuclear Waste Repository in the Southern Great Basin," US Geological Survey Open-File Report 80-375 (1980).

5. Crowe, B.M., "Major-Element Geochemistry of the Silent Canyon-Black Mountain Peralkaline Volcanic Centers, Northwestern Nevada Test Site: Applications to an Assessment of Renewed Volcanism," US Geological Survey Open-File Report 79-926, (1979). 
6. Crowe, B.M., and F.V. Perry, "Preliminary Geologic Map of the Sleeping Butte Volcanic Centers," Los Alamos National Laboratory report LA-12101-MS (1991).

7. Crowe, B.M., and F.V. Perry, "Volcanic Probability Calculations for the Yucca Mountain Site: Estimation of Volcanic Rates," in Proceedings of the Nuclear Waste Isolation in the Unsaturated Zone, Focus '89 Conference (American Nuclear Society, La Grange Park, Illinois, 1990), pp. 326-334.

8. Crowe, B.M., and K.A. Sargent, "Major-Element Geochemistry of the Silent CanyonBlack Mountain Peralkaline Volcanic Centers, Northwestern Nevada Test Site:

Applications to an Assessment of Renewed Volcanism," U. S. Geological Survey OpenFile Report 79-296 (1979).

9. Crowe, B.M., F.V. Perry, G.A. Valentine, P.C. Wallmann and R. Kossik, "Simulation Modeling of the Probability of Magmatic Disruption of the Potential Yucca Mountain Site," in Proceedings: Site Characterization and Model Validation Focus '93 (American Nuclear Society La Grange Park, Illinois, 1993), pp. 182-191.

10. Crowe B.M., R.A. Morley, S.G. Wells, J. Geissman, E. McDonald, L. McFadden, F.V. Perry, M. Murrell, J. Poths, and S. Forman, "The Lathrop Wells Volcanic Center: Status of Field and Geochronology Studies," in High Level Radioactive Waste Management: Proceedings of the Third International Conference, Las Vegas, Nevada, April 12-16, 1992 (American Nuclear Society, La Grange Park, Illinois, 1992) pp. 19972013.

11. Crowe, B.M., R. Picard, G. Valentine, and F.V. Perry, "Recurrence Models of Volcanic Events: Application to Volcanic Risk Assessment," in High Level Radioactive Waste Management: Proceedings of the Third International Conference, Las Vegas, Nevada, April 12-16, 1992 (American Nuclear Society, La Grange Park, Illinois, 1992), pp. 2344-2355.

12. Crowe, B.M., G.A. Valentine, R.A. Morley and F.V. Perry, "Recent Progress in Volcanism Studies: Site Characterization Activities for the Yucca Mountain Project," in Waste Management '92 1, (Arizona Board of Regents, Tucson, Arizona, 1992), pp. 921928.

13. Crowe, B.M., C.D. Harrington, B. Turrin, D. Champion, S.G. Wells, F.V. Perry, L.D. McFadden, and C. Renault, "Volcanic Hazard Studies for the Yucca Mountain Project," in Proceedings of Waste Management '89, R.B. Post, Ed., pp. 485-491 (1989).

14. Crowe, B.M., K.H. Wohletz, D.T. Vaniman, E. Gladney, and N. Bower, "Status of Volcanic Hazard Studies for the Nevada Nuclear Waste Storage Investigations," Los Alamos National Laboratory report LA-9325-MS, (1986).

15. Crowe, B.M., R. Amos, F.V. Perry, S. Self, and D.T. Vaniman, “Aspects of Potential Magmatic Disruption of a High-Level Radioactive Waste Repository in Southern Nevada," Journal of Geology 91, 259-276 (1983).

16. Crowe, B.M., D.T. Vaniman, and W.J. Carr, "Status of Volcanic Hazard Studies for the Nevada Nuclear Waste Storage Investigations," Los Alamos National Laboratory report LA-9325-MS (1983). 
17. Crowe, B.M., M.E. Johnson, and R.J. Beckman, "Calculation of the Probability of Volcanic Disruption of a High-Level Radioactive Waste Repository Within Southern Nevada, USA," Radioactive Waste Management of Nuclear Fuel Cycle 3, 167-190 (1982).

18. Crowe, B.M., D.T. Vaniman, F.V. Perry, R. Amos, and S. Self, "Aspects of Possible Magmatic Disruption of a High-Level Radioactive Waste Repository in Southern Nevada," Los Alamos National Laboratory report LA-9326-MS (1982).

19. Perry, F.V., and B.M. Crowe, "Geochemical Evidence for Waning Magmatism and Polycyclic Volcanism at Crater Flat, Nevada," in High Level Radioactive Waste Management: Proceedings of the Third International Conference, Las Vegas, Nevada, April 12-16, 1992 (American Nuclear Society, La Grange Park, Illinois, 1992), pp. 2356-2365.

20. Valentine G.A., K.R. Groves, C.W. Gable, F.V. Perry, and B.M. Crowe, "Effects of Magmatic Processes on the Potential Yucca Mountain Repository: Field and Computational Studies," in Proceedings: Site Characterization and Model Validation Focus '93 (American Nuclear Society La Grange Park, Illinois, 1993) pp. 167-173.

21. Valentine, G.A., B.M. Crowe, and F.V. Perry, "Physical Processes and the Effects of Magmatism in the Yucca Mountain Region," in High Level Radioactive Waste Management: Proceedings of the Third International Conference, Las Vegas, Nevada, April 12-16, 1992, (American Nuclear Society, La Grange Park, Illinois, 1992), pp. 2014-2024.

22. Vaniman, D.T., and B.M. Crowe, "Geology and Petrology of the Basalts of Crater Flat: Applications to Volcanic Risk Assessment for the Nevada Nuclear Waste Storage Investigations," Los Alamos Scientific Laboratory report LA-8845-MS (1981).

23. Vaniman, D.T., B.M. Crowe, and E.S. Gladney, "Petrology and Geochemistry of Hawaiite Lavas from Crater Flat, Nevada," Contributions to Mineralogy and Petrology 80, (1982).

24. Wells, S.G., B.M. Crowe and L.D. McFadden, "Measuring the Age of the Lathrop Wells Volcanic Center at Yucca Mountain," Science 257, 555-556 (1992).

25. Wells, S.G., L.D. McFadden, C.E. Renault, and B.M. Crowe, "Reply on Geomorphic Assessment of Late Quaternary Volcanism in the Yucca Mountain Area, Southern Nevada: Implications for the Proposed High-Level Radioactive Waste Repository," Geology 19, 661-662 (1991).

26. Wells, S.G., L.D. McFadden, C.E. Renault, and B.M. Crowe, "Geomorphic Assessment of Late Quaternary Volcanism in the Yucca Mountain Area, Southern Nevada: Implications for the Proposed High-Level Radioactive Waste Repository," Geology 18, 549-553 (1990). 


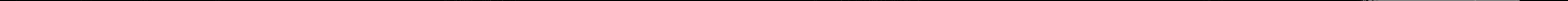




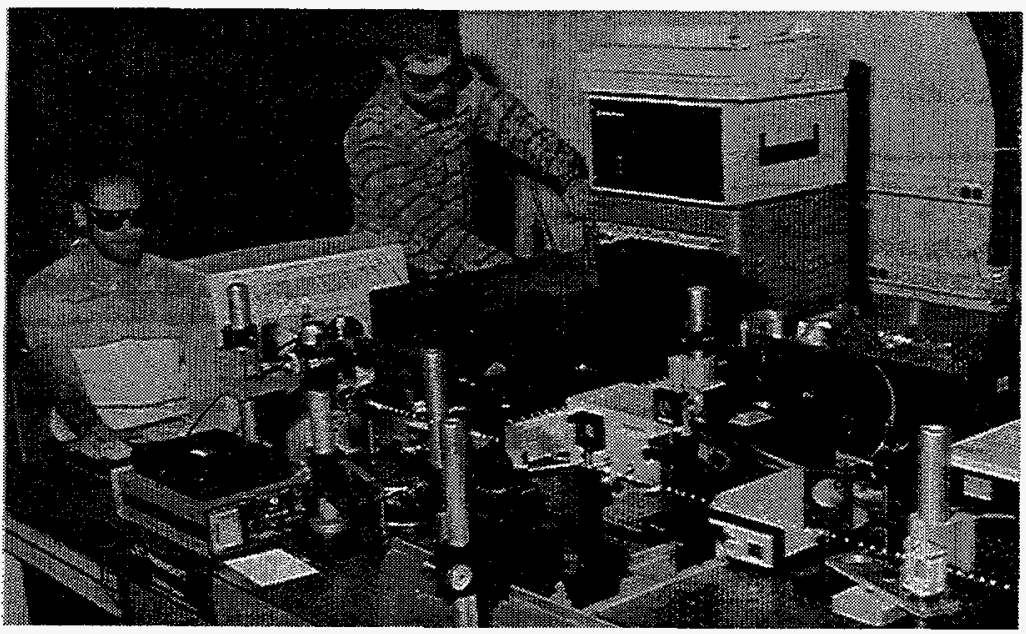

Staff using $a$ newly developed laser-based spectroscopy technique, called photothermal detection spectroscopy, to obtain an absorption spectrum for plutonium.

\section{Radionuclide Solubility/Groundwater Chemistry}

1. Benson, L.V., J.H. Robinson, R.K. Blankennagel, and A.E. Ogard, "Chemical Composition of Groundwater and the Locations of Permeable Zones in the Yucca Mountain area, Nevada," US Geological Survey Open-File Report 83-854, (1983).

2. Clark, D.L., J.G. Watkin, D.E. Morris, and J.M. Berg, "Molecular Models for Actinide Speciation," Los Alamos National Laboratory report LA-12780-MS (1994).

3. Clark, D.L., S.A. Ekberg, D.E. Morris, P.D. Palmer, C.D. Tait, "Actinide (IV) and Actinide (VI) Carbonate Speciation Studies by PAS and NMR Spectroscopies," Los Alamos National Laboratory report LA-12820-MS (1994).

4. Combes, J.M., C.J.Chisholm-Brause, G.E. Brown, Jr., G.A. Parks, S.D. Conradson, P.G. Eller, I.R. Triay, D.E. Hobart, and A. Meijer, "X-ray Adsorption Spectroscopy Study of Neptunium(V) Sorbed at the $\alpha-F e o o H / W a t e r$ Interface," Environmental Science and Technology 26, 376-382 (1992).

5. Ebinger, M.H., "Water-Rock Interactions and the pH Stability of Groundwaters from Yucca Mountain, Nevada," in Water-Rock Interaction, Proceedings of the 7th International Symposium on Water-Rock Interaction, WRI-7, Park City Utah, USA, 13-18 July 1992, (A.A. Balkema, Rotterdam and Brookfield, Capetown, South Africa, 1992) pp. 783-786. 
6. Gatti, R.C., and S.C. Lee, "Determination of Plutonium Oxidation States at Trace Levels Pertinent to Nuclear Waste Disposal," in International Conference on Methods and Applications of Radioanalytical Chemistry, Kona, Hawaii, 27 (1987).

7. Hobart, D.E., D.E. Morris, P.D. Palmer, and T. Newton, "Formation, Characterization, and Stability of Pu(IV) Colloid," in Proceedings of the Nuclear Waste Isolation in the Unsaturated Zone, Focus '89 Conference (American Nuclear Society, La Grange Park, Illinois, 1990), pp. 118-124.

8. Hobart D.E., P.D. Palmer and T.W. Newton, "Carbonate Complexation of Plutonium(IV): The Competition by Citrate Ligands," Los Alamos National Laboratory report LA-11034-PR (1986).

9. Kerrisk, J.F., "Groundwater Chemistry at Yucca Mountain, Nevada, and Vicinity," Los Alamos National Laboratory report LA-10929-MS (1987).

10. Kerrisk, J.F., "Solubility Experiments for the Nevada Nuclear Waste Storage Investigations Project," Los Alamos National Laboratory report LA-10560-MS (1985).

11. Kerrisk, J.F., "An Assessment of the Important Radionuclides in Radioactive Waste," Los Alamos National Laboratory report LA-10414-MS (1985).

12. Kerrisk, J.F., "Americium Thermodynamic Data for the EQ3/6 Database," Los Alamos National Laboratory report LA-10040-MS (1984).

13. Kerrisk, J.F., "Solubility Limits on Radionuclide Dissolution at a Yucca Mountain Repository," Los Alamos National Laboratory report LA-9995-MS (1984).

14. Kerrisk, J.F., "Reaction Path Calculations of Groundwater Chemistry and Mineral Formation at Rainier Mesa, Nevada," Los Alamos National Laboratory report LA-9912-MS (1983).

15. Kerrisk, J.F., and R.J. Silva, "A Consistent Set of Thermodynamic Constants for Americium (III) Species with Hydroxyl and Carbonate," in Proceedings of Workshop on Geochemical Modeling, Fallen Leaf Lake, California, September 14-17 167-175 (1986).

16. Newton, T.W., and V.L. Rundberg, "Disproportionation and Polymerization of Plutonium (IV) in Dilute Aqueous Solutions," in Proceedings of the Materials Research Society Annual Meeting, Boston, Massachusetts, November 13-18, 1983 (Materials Research Society, Pittsburgh, Pennsylvania, 1983), pp. 867-873.

17. Newton, T.W., D.E. Hobart, and P.D. Palmer, "The Formation of Pu(IV)-Colloid by the Alpha-Reduction of Pu(V) or Pu(VI) in Aqueous Solutions," Radiochimica Acta 39, 139-147 (1986).

18. Nitsche, H., "Solubility Studies of Transuranium Elements for Nuclear Waste Disposal; Principles and Overview," Chemistry and Migration Behavior of Actinides and Fission Products in the Geosphere, Second International Conference, Monterey, California, Nov. 6-10, 1989, Radiochimica Acta 52/53, 3-8 (1991). 
19. Nitsche, H., "The Importance of Transuranium Solids in Solubility Studies for Nuclear Waste Repositories," in International Symposium on the Scientific Basis for Nuclear Waste Management XV,U.S., and European Materials Research Societies Meeting, Strasbourg, France November 5-8, 289-298 (1991).

20. Nitsche, H., "Basic Research for Assessment of Geologic Nuclear Waste Repositories: What Solubility and Speciation Studies of Transuranium Elements Can Tell Us," in Scientific Basis for Nuclear Waste Management VII, Materials Research Society Symposia Proceedings, Boston, Massachusetts L. McVay, Ed., (Materials Research Society, Pittsburgh, Pennsylvania, 1991), pp. 517-529.

21. Nitsche, H.N., K. Roberts, T. Prussin, A. Muller, K. Becraft, D. Keeny, S.A. Carpenter, and R.C. Gatti, "Measured Solubilities and Speciations from Oversaturation Experiments of Neptunium, Plutonium and Americium in UE-25p \#1 Well Water from the Yucca Mountain Region," Los Alamos National Laboratory report LA-12563-MS (1994).

22. Nitsche, H.N., R.C. Gatti, E.M. Standifer, S.C. Lee, A. Muller, T. Prussin, R.S. Deinhammer, H. Maurer, K. Becraft, S. Leung, and S.A. Carpenter, "Measured Solubilities and Speciations of Neptunium, Plutonium, and Americium in a Typical Groundwater (J-13) from the Yucca Mountain Region," Los Alamos National Laboratory report LA-12562-MS (1993).

23. Nitsche, H., K. Roberts, T. Prussin, D. Keeney, S.A. Carpenter, K. Becraft, and R.C. Gatti, "Radionuclide Solubility and Speciation Studies for the Yucca Mountain Site Characterization Project," in High Level Waste Management: Proceedings of the Fourth Annual International Conference, Las Vegas, Nevada, April 26-30, 1993 (American Nuclear Society, La Grange Park, Illinois, 1993), pp. 1490-1495.

24. Nitsche, H., R.C. Gatti, and S.C. Lee, "Low-Level Determination of Plutonium by Gamma and L-X-ray Spectroscopy," in Proceedings of International Topical Conference on Methods and Applications of Radioanalytical Chemistry-II, April 21-27, 1991, Kona, Hawaii, 401-411 (1991).

25. Nitsche, H., E.M. Standifer, and R.J. Silva, "Americium(III) Carbonate Complexation in Aqueous Perchlorate Solution,” Radiochimica Acta 46, 185 (1989).

26. Nitsche, H., S.C. Lee, and R.C. Gatti, "Determination of Plutonium Oxidation States at Trace Levels Pertinent to Nuclear Waste Disposal," Journal of Radioanalytical and Nuclear Chemistry 124, 1 (1988).

27. Nuttall H.E., R. Jain, and Y. Fertelli, "Radiocolloid Transport in Saturated and Unsaturated Fractures," High Level Radioactive Waste Management: Proceedings of the Second Annual International Conference, Las Vegas, Nevada, April 28-May 3, 1991, (American Nuclear Society, La Grange Park, Illinois, 1991), pp. 189-196.

28. Ogard, A.E., and J.F. Kerrisk, "Groundwater Chemistry Along Flow Paths Between a Proposed Repository Site and the Accessible Environment," Los Alamos National Laboratory report LA-10188-MS (1984). 
29. Ogard, A.E., P.L. Wanek, S. Maestas, A.J. Mitchell, R.D. Aguilar, and M.R. Cisneros, "Groundwater Chemistry of Yucca Mountain," Los Alamos National Laboratory report LA-10130-PR, pp. 110-113 (1984).

30. Robinson, B.A., "A Strategy for Validating a Conceptual Model for Radionuclide Migration in the Saturated Zone Beneath Yucca Mountain," Radioactive Waste Management and Environmental Restoration 19, 73-96 (1994)

31. Rundberg, R.S., A.J. Mitchell, I.R. Triay, B.J. Torstenfeld, M.J. Apted, and E. Westerman, Eds., "Size and Density of a ${ }^{242}$ Pu Colloid," in Scientific Basis for Nuclear Waste Management XI, Material Research Society Symposium Proceedings (Materials Research Society, Pittsburgh, Pennsylvania, 1988), pp. 243-248.

32. Standifer, E.M., and H. Nitsche, "First Evidence for Hexagonal $\mathrm{AmOHCO}_{3}$," Lanthanide and Actinide Research 2, 383 (1988).

33. Tait, C.D., D.E. Morris, S.A. Ekberg, and P.D. Palmer, "Speciation of Pu(IV) in Carbonate Media," in Program of the Materials Research Society, November 30December 4, 1992 (Materials Research Society, Pittsburgh, Pennsylvania, 1993), p. 595.

34. Thompson, J.L., "Actinide Behavior on Crushed Rock Columns," Journal of Radioanalytical and Nuclear Chemistry 130, 353-364 (1989).

35. Travis, B.J., and H.E. Nuttall, " Analysis of Colloid Transport," Material Research Society Symposium Proceedings 50, 737-745 (1985).

36. Travis, B.J., and H.E. Nuttall, "A Transport Code for Radiocolloid Migration: With an Assessment of an Actual Low-Level Waste Site," Material Research Society Symposium Proceedings 44, 969-976 (1985).

37. Triay, I.R., D.E. Hobart, A.J. Mitchell, T.W. Newton, M.A. Ott, P.D. Palmer, S. Rundberg, and J.L. Thompson, "Size Determinations of Plutonium Colloids Using Autocorrelation Photon Spectroscopy," in Chemistry and Migration Behavior of Actinides and Fission Products in the Geosphere, Second International Conference Monterey, California, Nov 6-10, 1989, Radiochimica Acta 52/53, 127-131 (1991).

38. Tucker, D.T., E.M. Standifer, and H. Nitsche, "Data Acquisition and Feedback Control System for Solubility Studies of the Nuclear Waste Elements Neptunium and Plutonium," Lanthanide and Actinide Research 2, 279 (1988). 


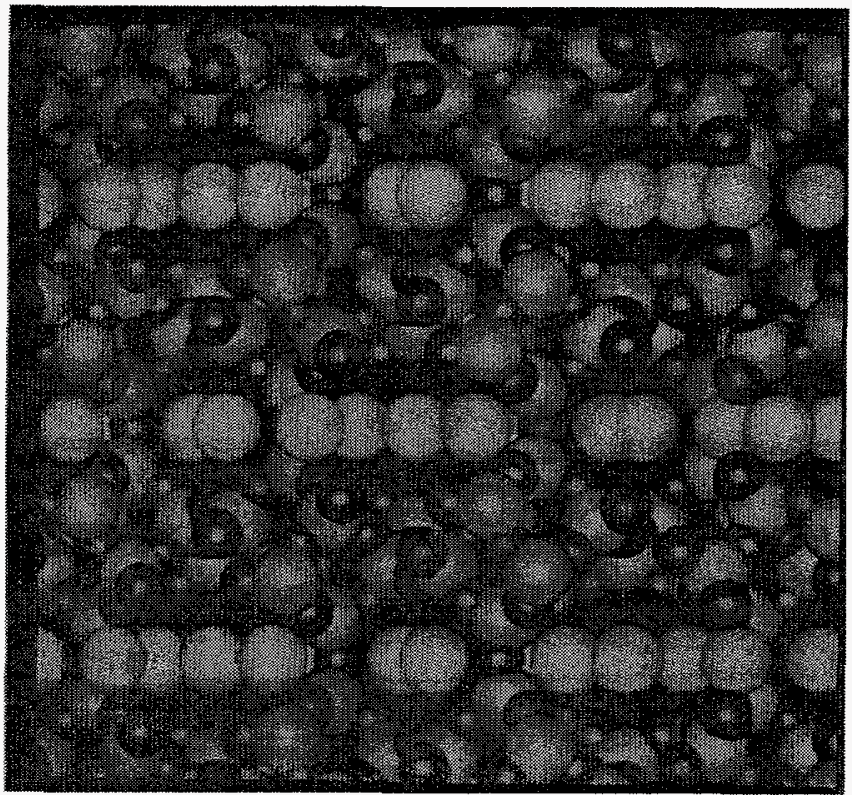

Molecular model of Clinoptilolite

\section{Radionuclide Sorption and Transport}

1. Beckman, R.J., K.W. Thomas, and B.M. Crowe, "Preliminary Report on the Statistical Evaluation of Sorption Data: Sorption as a Function of Mineralogy, Temperature, Time and Particle Size," Los Alamos National Laboratory report LA-11246-MS (1988).

2. Bischke, S.D., R. Chemburkar, L.F. Brown, B.J. Travis, and D.L. Bish, "The Extraction of Site-Energy Distributions from Temperature-Programmed Desorption Spectra," in American Institute of Chemical Engineers Annual Meeting, Washington, D. C. November 28 - December 2, (1988).

3. Birdsell, K.H., K.G. Eggert, and B.J. Travis, "Three Dimensional Simulations of

Radionuclide Transport at Yucca Mountain," Radioactive Waste Management and Environmental Restoration 19, 1-28 (1994).

4. Bish, D.L., D.T. Vaniman, R.S. Rundberg, K. Wolfsberg, W.R. Daniels, and E. Broxton, "Natural Sorptive Barriers in Yucca Mountain, Nevada, for Long Term Isolation of High-Level," Radioactive Waste Management 3, 415-432 (1984).

5. Campbell, K., "Lateral Continuity of Sorptive Mineral Zones Underlying Yucca Mountain, Nevada," Los Alamos National Laboratory report LA-11070-MS (1987). 
6. Canepa, J.A., Compiler, "Proceedings of the DOE/Yucca Mountain Site Characterization Project Radionuclide Adsorption Workshop at Los Alamos National Laboratory, September 11-12, 1990," Los Alamos National Laboratory Report LA-12325-C (1992).

7. Chipera, S.J., and D.L. Bish, "Quantitative X-ray Diffraction Analyses of Samples Used for Sorption Studies by the Isotope and Nuclear Chemistry Division, Los Alamos National Laboratory," Los Alamos National Laboratory report LA-11669-MS (1989).

8. Clark, D.L. and P. Palmer, "Oxygen-17 and Carbon-13 NMR Studies of Uranyl and Neptunyl Carbonate Complexes in Near-neutral Solution," in Chemistry and Migration Behavior of Actinides and Fission Products in the Geosphere: Proceedings of the Fourth International Conference, Charleston, South Carolina, USA, December 12-17, 1993, p. 32 (1994).

9. Conca, J.L., and I.R. Triay, "Selenite Transport in Unsaturated Tuff from Yucca Mountain," in High Level Radioactive Waste Management: Proceedings of the Fifth Annual International Conference, Las Vegas, Nevada, May 22-26, 1994, (American Nuclear Society, La Grange Park, Illinois, 1994), pp. 1275-1282.

10. Conca, J.L., "Measurement of Unsaturated Hydraulic Conductivity in Yucca Mountain Tuff," Los Alamos National Laboratory report LA-12596-MS (1993).

11. Conca, J.L., "Diffusion Barrier Properties of Unsaturated Paintbrush Tuff Rubble Backfill," High Level Radioactive Waste Management: Proceedings of the First Annual International Topical Meeting, April 8-12, 1990 (American Nuclear Society, La Grange Park, Illinois, 1990), pp. 394-401.

12. Conca, J.L., and J. Wright, "Effect of Meteoric Infiltration on the Aqueous Chemistry of Paintbrush Tuff During Exposure at the Surface," Radioactive Waste Management and the Nuclear Fuel Cycle 15, 27-41 (1990).

13. Erdal, B.R., D.L. Bish, B.M. Crowe, W.R. Daniels, A.E. Ogard, R.S. Rundberg, D.T. Vaniman, and K. Wolfsberg, "Some Geochemical Considerations for a Potential Repository Site in Tuff at Yucca Mountain, Nevada," in Proceedings of the U. S./F.R.G. Bilateral Workshop Berlin, West Germany, 21 (1983).

14. Erdal, B.R., B.P. Bayhurst, B.M. Crowe, W.R. Daniels, D.C. Hoffman, F.O. Lawrence, J.R. Smyth, J.L. Thompson, and K. Wolfsberg, "Laboratory Studies of Radionuclide Transport in Geologic Media," in Proceedings of the LAEA/OFCD Symposium on the Underground Disposal of Radioactive Wastes, Volume II, (International Atomic Energy Agency, Vienna, Austria, 1980) Report IAEA-SM-243/37, pp. 367-382.

15. Erdal, B.R., B.P. Bayhurst, W.R. Daniels, S.J. DeVilliers, G.H. Heiken, F.O. Lawrence, M.L. Sykes, J.R. Smyth, J.L. Thompson, E.N. Vine, and K. Wolfsberg, "Parameters Affecting Radionuclide Migration in Geologic Media," in Scientific Basis for Nuclear Waste Management 2, 609-616 (1980). 
16. Erdal, B.R., B.P. Bayhurst, W.R. Daniels, S.J. DeVilliers, F.O. Lawrence, L. Thompson, and K. Wolfsberg, "Parameters Affecting Radionuclide Migration in Argillaceous Media," in Use of Argillaceous Materials for the Isolation of Radioactive Waste, Proceedings of the NEA Workshop, Paris, France; September 10-12, 1979, 55-66 (1980).

17. Erdal, B.R., R.D. Aguilar, B.P. Bayhurst, W.R. Daniels, C.J. Duffy, F.O. Lawrence, S. Maestas, P.Q. Oliver, and K. Wolfsberg, "Sorption-Desorption Studies on Granite. I. Initial Studies of Strontium, Technetium, Cesium, Barium, Cerium, Europium, Uranium, Plutonium, and Americium," Los Alamos Scientific Laboratory report LA-7456-MS (1979).

18. Erdal, B.R., R.D. Aguilar, B.P. Bayhurst, P.Q. Oliver, and K. Wolfsberg, "SorptionDesorption Studies on Argillite. I. Initial Studies of Strontium, Technetium. Cesium, Barium, Cerium, Europium, Uranium, Plutonium, and Americium," Los Alamos Scientific Laboratory report LA-7455-MS (1979).

19. Erdal, B.R., W.R. Daniels, D.C. Hoffman, F.O. Lawrence, and K. Wolfsberg, "Sorption and Migration of Radionuclides in Geologic Media," Scientific Basis for Nuclear Waste Management 1, 423-426 (1979).

20. Finnegan, D.L., and E.A. Bryant, "Methods for Obtaining Sorption Data From UraniumSeries Disequilibria," Los Alamos National Laboratory report LA-11162-MS (1987).

21. Fuentes, H.R., W.L. Polzer, E.H. Essington, and B.D. Newman, "Characterization of Reactive Tracers for C-Wells Field Experiments I: Electrostatic Sorption Mechanism, Lithium," Los Alamos National Laboratory report LA-11691-MS (1989).

22. Fuentes, H.R., W.L. Polzer, J. Gruber, B. Lauctes, and E.H. Essington, "Preliminary Report on Sorption Modeling," Los Alamos National Laboratory report LA-10952-MS (1987).

23. Hawley, M.E., I.D. Raistrick, J.G. Geery, and R.J. Houlton, "Growth Mechanism of Sputter Films of $\mathrm{YBa}_{2} \mathrm{Cu}_{3} \mathrm{O}_{7}$ Studied by Scanning Tunneling Microscopy," Science 251, 1587-1589 (1991).

24. Hersman, L.E., P.D. Palmer, and D.E. Hobart, "The Role of Siderophores in the Transport of Radionuclides," in Materials Research Society Symposium Proceedings November 30 -December 4, 1993 294, (Materials Research Society, Pittsburgh, Pennsylvania, 1993), pp. 765-770.

25. Janecky, D.R., R.S. Rundberg, M.A. Ott, and A.J. Mitchell "Update Report on Fracture Flow in Saturated Tuff; Dynamic Transport Task for the Nevada Nuclear Waste Investigations," Los Alamos National Laboratory report LA-11957-MS (1990).

26. Kung, K.S., and I.R. Triay, "Effect of Natural Organics on Cd and Np Sorption," in Chemistry and Migration Behavior of Actinides and Fission Products in the Geosphere: Radiochimica Acta 66/67, 421-426 (1994).

27. Ledergerber, G., R. Herbst, H.U. Zwicky, H. Kutter, and P. Fisher, "Characterization and Quality Control of Uranium-Plutonium Carbide for the AC-3/FFTF Experiment," Journal of Nuclear Materials 153, 189-204 (1988). 
28. Meijer, A., "Far-Field Transport of Carbon Dioxide Retardation Mechanisms and Possible Validation Experiments," Proceedings: Site Characterization and Model Validation Focus '93 (American Nuclear Society, La Grange Park, Illinois, 1993), pp. 110-112.

29. Meijer, A., "A Strategy for the Derivation and Use of Sorption Coefficients in Performance Assessment Calculations for the Yucca Mountain Site," in Proceedings of the DOE/Yucca Mountain Site Characterization Project Radionuclide Adsorption Workshop at Los Alamos National Laboratory, September 11-12, 1990, J.A. Canepa, Compiler, Los Alamos National Laboratory report LA-12325-C, pp. 9-40 (1992).

30. Meijer, A., "Yucca Mountain Project Far-Field Sorption Studies and Data Needs," Los Alamos National Laboratory report LA-11671-MS (1990).

31. Meijer, A., I.R. Triay, S. Knight, and M.R. Cisneros, "Sorption of Radionuclides on Yucca Mountain Tuffs," in Proceedings of the Nuclear Waste Isolation in the Unsaturated Zone, Focus '89 Conference (American Nuclear Society, La Grange Park, Illinois, 1990), pp. 113-117.

32. Newman, B.D., H.R. Fuentes, and W.L. Polzer, "An Evaluation of Lithium Sorption Isotherms and their Application to Groundwater Transport," Groundwater 20, 818-824 (1991).

33. Ogard, A.E., K. Wolfsberg, W.R. Daniels, J.F. Kerrisk, R.S. Rundberg, and W. Thomas, "Retardation of Radionuclides by Rock Units Along the Path to the Accessible Environment," in Proceedings of the Materials Research Society Annual Meeting, Boston, Massachusetts, November 13-18, 1983 (Materials Research Society, Pittsburgh, Pennsylvania, 1983), pp. 329-336.

34. Penrose, W.R., W.L. Polzer, E.H. Essington, D.M Nelson, and K.A. Orlandini, "Mobility of Plutonium and Americium Through a Shallow Aquifer in a Semiarid Region," Environmental Science and Technology 24, 228-234 (1990).

35. Patera, E.S., D.E. Hobart, A. Meijer, and R.S. Rundberg, "Chemical and Physical Processes of Radionuclide Migration at Yucca Mountain, Nevada," Journal of Radioanalytical and Nuclear Chemistry 142, 331-347 (1990).

36. Polzer W.L., E.H. Essington, K.M. Fellenz and J.R. McLeod, "The Use of Selectivity Coefficients to Estimate Modified Langmuir Isotherm Parameters as a Function of Experimental Conditions," Radioactive Waste Management and Environmental Restoration 19, 107-128 (1994).

37. Polzer, W.L., M.G. Rao, H.R. Fuentes, and R.J. Beckman "Thermodynamically Derived Relationships Between the Modified Langmuir Isotherm and Experimental Parameters," Environmental Science and Technology 26, 1780-1786 (1992).

38. Polzer, W.L., and H.R. Fuentes, "Fitting a Modified Langmuir Isotherm to Data from Batch Sorption Experiments for Radionuclides on Tuffs," Radiochimica Acta 52/53, 177-179 (1991). 
39. Polzer, W.L., and H.R. Fuentes, "The Use of a Heterogeneity-Base Isotherm to Interpret the Transport of Radionuclides in Volcanic Tuff Media," Radiochimica Acta 41/45, 361365 (1988).

40. Reimus, P.W., B.A. Robinson, H.E. Nuttall, and R. Kale, "Transport of Synthetic Colloids and a Nonsorbing Solute through a Saturated Natural Fracture," in Proceedings of the March 1994 meeting of the American Chemical Society, San Diego CA, 569 (1994).

41. Reimus, P., R. Glass, and B. Robinson, "Aperture Characteristics, Saturated Fluid Flow, and Tracer Transport Calculations for a Natural Fracture," in High Level Waste Management: Proceedings of the Fourth Annual International Conference, Las Vegas, Nevada, April 26-30, 1993 (American Nuclear Society, La Grange Park, Illinois, 1993), pp. 2009-2016.

42. Robinson, B.A., "A Fracture Network Model for Water Flow and Solute Transport," in 1989 Eastern Multiconference, Tampa Florida, March 28-31, 21 (1989).

43. Rogers, P.Z. and A. Meijer, "Dependence of Radionuclide Sorption on Sample Grinding, Surface Area, and Water Composition, in High Level Waste Management: Proceedings of the Fourth Annual International Conference, Las Vegas, Nevada, April 26-30, 1993 (American Nuclear Society, La Grange Park, Illinois, 1993), pp. 1509-1516.

44. Rundberg, R.S., "A Suggested Approach Toward Measuring Sorption and Applying Sorption Data to Repository Performance Assessment," in Proceedings of the NEA Sorption Workshop Held at Interlaken, Switzerland, October 14-19, 1991, 187-215 (1991).

45. Rundberg, R.S., "Assessment Report on the Kinetics of Radionuclide Adsorption on Yucca Mountain Tuff," Los Alamos National Laboratory report LA-11026-MS (1987).

46. Rundberg, R.S., "The Kinetics of the Adsorption of Radionuclides on Tuff from Yucca Mountain, Nevada," in Proceedings of the Materials Research Society Annual Meeting, Boston, Massachusetts, November 13-18, 1983, (Materials Research Society, Pittsburgh, Pennsylvania, 1983), pp. 827-834.

47. Rundberg, R.S., I.R. Triay, M.A. Ott, and A.J. Mitchell, "Observation of Time Dependent Dispersion in Laboratory Scale Experiments with Intact Tuff," in Chemistry and Migration Behavior of Actinides and Fission Products in the Geosphere, Second International Conference Monterey, CA, November 6-10, 1989 Radiochimica Acta 52/53, 219-228 (1991).

48. Rundberg, R.S., A.J. Mitchell, M.A. Ott, J. Thompson, and I.R. Triay, "Laboratory Studies of Radionuclide Migration in Tuff," in Proceedings of the Nuclear Waste Isolation in the Unsaturated Zone, Focus ' 89 Conference (American Nuclear Society, La Grange Park, Illinois, 1990), 248-255.

49. Rundberg, R.S., A.E. Ogard, and D.T. Vaniman, Compilers, "Research and Development Related to the Nevada Nuclear Waste Storage Investigations, April 1 - June 30, 1984," Los Alamos National Laboratory report LA-10297-PR (1985). 
50. Rundberg, R.S., J.L. Thompson, S. Maestas, and S.V. Topp, "Radionuclide Migration: Laboratory Experiments with Isolated Fractures," in Annual Meeting of the Materials Research Society in Boston Massachusetts, November 15, 1981, 239-348 (1982).

51. Smyth, J.R., J.L. Thompson, and K. Wolfsberg, "Microautoradiographic Studies of the Sorption of U and Am on Natural Rock Samples," Radioactive Waste Management 1, 13-24 (1980).

52. Springer, E.P., M.D. Siegel, P.L. Hopkins, and R.J. Glass, "Testing models of flow and transport in unsaturated porous media," in High Level Waste Management: Proceedings of the Fourth Annual International Conference, Las Vegas, Nevada, April 26-30, 1993 (American Nuclear Society, La Grange Park, Illinois, 1993), pp. 336-347.

53. Thomas, K.W., "Summary of Sorption Measurements Performed with Yucca Mountain, Nevada, Tuff Samples and Water from Well J-13," Los Alamos National Laboratory report LA-10960-MS (1987).

54. Thompson, J.L., and K. Wolfsberg, "Applicability of Microautoradiography to Sorption Studies," Los Alamos Scientific Laboratory report LA-7609-MS (1979).

55. Travis, B.J., and H.E. Nuttall, "Two-Dimensional Numerical Simulation of Geochemical Transport in Yucca Mountain," Los Alamos National Laboratory report LA-10532-MS (1987).

56. Treher, E.N., and N.A. Raybold, "The Elution of Radionuclides through Columns of Crushed Rock from the Nevada Test Site," Los Alamos National Laboratory report LA-9329-MS (1982).

57. Triay, I.R., and R.S. Rundberg, "Application of Deconvolution to the Analysis of Univalent Ion-Exchange Isotherms in Zeolites X and Y," Zeolites 9, $217-223$ (1989).

58. Triay, I.R., and R.S. Rundberg, "Deconvolution of Multivalent Cation-Exchange Isotherms," The Journal of Physical Chemistry 93, 5617-5623 (1989).

59. Triay, I.R., and R.S. Rundberg, "Determination of Selectivity Coefficient Distribution by Deconvolution of Ion-Exchange Isotherms," Journal of Physical Chemistry 91, 52695274 (1987).

60. Triay, I.R., K.H. Birdsell, A.J. Mitchell, and M.A. Ott, "Diffusion of Sorbing and Nonsorbing Radionuclides in Tuff," in High Level Waste Management: Proceedings of the Fourth Annual International Conference, Las Vegas, Nevada, April 26-30, 1993 (American Nuclear Society, La Grange Park, Illinois, 1993), pp. 1527-1532.

61. Triay, I.R., M.A. Ott, A.J. Mitchell, and C.M. Overly, "Transport of Neptunium through Yucca Mountain Tuffs," in Scientific Basis for Nuclear Waste Management XVI, C.J. Interrante and R.T. Pabalan, Eds. (Materials Research Society, Pittsburgh, Pennsylvania, 1993), pp. 797-802. 
62. Triay, I.R., B.A. Robinson, R.M. Lopez, A.J. Mitchell, and C.M. Overly, "Neptunium Retardation with Tuffs and Ground-waters from Yucca Mountain," in High Level Waste Management: Proceedings of the Fourth Annual International Conference, Las Vegas, Nevada, April 26-30, 1993 (American Nuclear Society, La Grange Park, Illinois, 1993), pp. 1504-1508.

63. Triay, I.R., A.J. Mitchell, and M.A. Ott, "Radionuclide Migration Studies for Validation of Batch Sorption Data," in Proceedings of the DOE/Yucca Mountain Site

Characterization Project Radionuclide Adsorption Workshop at Los Alamos National Laboratory, September 11-12, 1990, J.A. Canepa, Compiler, Los Alamos National Laboratory report LA-12325-C, pp. 91-109 (1992).

64. Triay, I.R., A. Meijer, M.R. Cisneros, G.G. Miller, A.J. Mitchell, M.A. Ott, E. Hobart, P.D. Palmer, R.E. Perrin, and D.R. Aguilar, "Sorption of Americium in Tuff and Pure Minerals Using Synthetic and Natural Groundwaters," in Chemistry and Migration Behavior of Actinides and Fission Products in the Geosphere, Second International Conference Monterey, California, November 6-10, 1989 Radiochimica Acta 52/53, 141145 (1991).

65. Triay, I.R., A.J. Mitchell, and M.A. Ott, "Radionuclide Migration as a Function of Mineralogy," in High Level Radioactive Waste Management: Proceedings of the Second Annual International Conference Las Vegas, Nevada, April 28-May 3, 1991, (American Nuclear Society, La Grange Park, Illinois, 1991), pp. 494-498.

66. Vine, E.N., B.P. Bayhurst, W.R. Daniels, S.J. DeVilliers, B.R. Erdal, F.O. Lawrence, and A. Wolfsberg, "Radionuclide Transport and Retardation in Tuff," in Scientific Basis for Nuclear Waste Management 3, 483-490 (1981).

67. Vine, E.N., R.D. Aguilar, B.P. Bayhurst, W.R. Daniels, S.J. DeVilliers, B.R. Erdal, F.O. Lawrence, S. Maestas, P.Q. Oliver, J.L. Thompson, and K. Wolfsberg, "SorptionDesorption Studies on Tuff. II. A Continuation of Studies With Samples from Jackass Flats, Nevada, and Initial Studies With Samples from Yucca Mountain, Nevada," Los Alamos Scientific Laboratory report LA-8110-MS (1980).

68. Walter, G.R., "Theoretical and Experimental Determination of Matrix Diffusion and Related Solute Transport Properties of Fractured Tuffs from the Nevada Test Site," Los Alamos National Laboratory report LA-9471-MS (1982).

69. Wolfsberg, K., R.D. Aguilar, B.P. Bayhurst, W.R. Daniels, S.J. DeVilliers, B.R. Erdal, F.O. Lawrence, S. Maestas, A.J. Mitchell, P.Q. Oliver, N.A. Raybold, R.S. Rundberg, L. Thompson, and E.N. Vine, "Sorption-Desorption Studies on Tuff. III. A Continuation of Studies with Samples from Jackass Flats and Yucca Mountain, Nevada," Los Alamos National Laboratory report LA-8747-MS (1981).

70. Wolfsberg, K., B.P. Bayhurst, B.M. Crowe, W.R. Daniels, B.R. Erdal, F.O. Lawrence, E. Norris, and J.R. Smyth, "Sorption-Desorption Studies on Tuff. I. Initial Studies With Samples From the J-13 Drill Site, Jackass Flats, Nevada," Los Alamos Scientific Laboratory report LA-7480-MS (1979). 


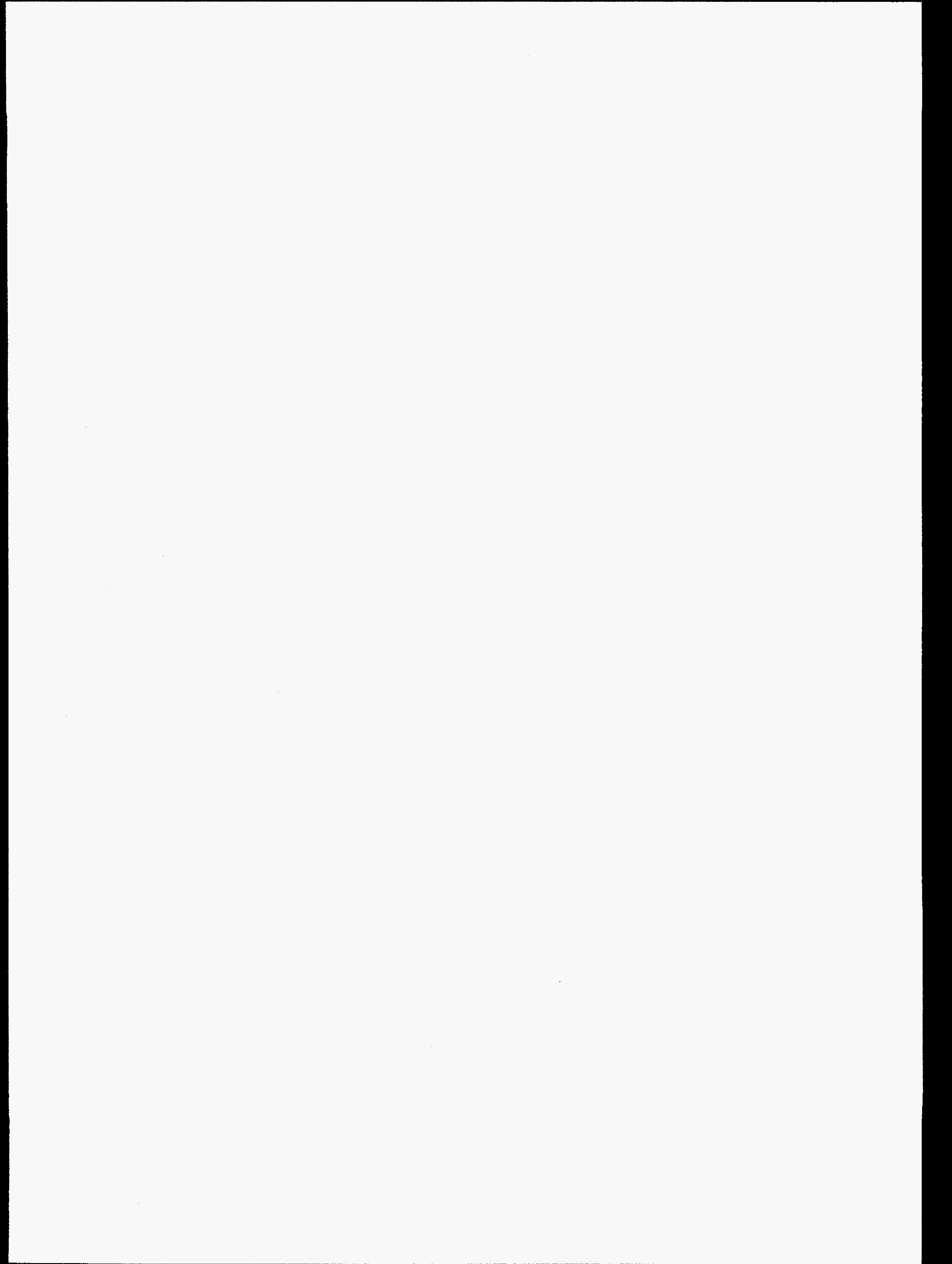




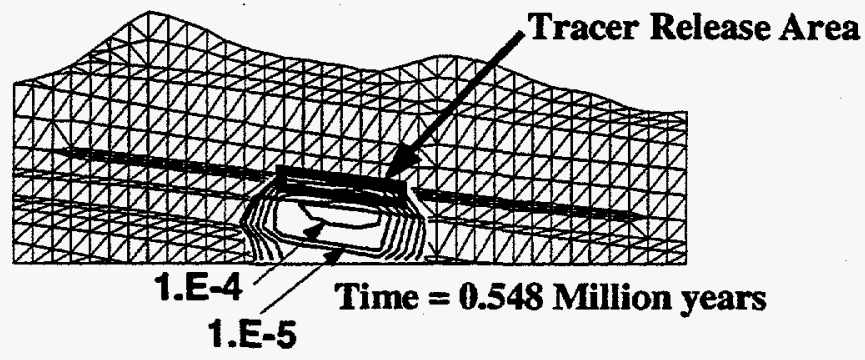

Simulated Np Concentration profile assuming a leak from a section of the Yucca Mountain potential repository over a short time period. Np distribution after 547,945 years is shown by seven isoconcetration lines at concentration $=E-4,1 . E-5, . . E-6$ ... I.E-10

\section{Modeling/Validation/Field Studies}

1. Bentley, H.W., S.K. Gifford, A.E. Norris, and K. Wolfsberg, "Measurements of Infiltration at Yucca Mountain," Los Alamos National Laboratory report LA-10709-PR, pp. $75-77$ (1986).

2. Birdsell, K.H., and B.J. Travis, "Results of the COVE2a Benchmarking Calculations Run with TRACR3D," Los Alamos National Laboratory report LA-11513-MS (1991).

3. Birdsell, K.H., K. Campbell, K.G. Eggert, and B.J. Travis, "Sensitivity Analysis of Integrated Radionuclide Transport Based on a Three-dimensional Geochemical/Geophysical Model," in Proceedings of the DOE/Yucca Mountain Site Characterization Project Radionuclide Adsorption Workshop at Los Alamos National Laboratory, September 11-12, 1990, J.A. Canepa, Compiler, Los Alamos National Laboratory report LA-12325-C, pp. 187-224 (1992).

4. Birdsell, K.H., K. Campbell, K.G. Eggert, and B.J. Travis, "Simulation of Radionuclide Retardation at Yucca Mountain Using Stochastic Mineralogical/Geochemical Model," in High Level Radioactive Waste Management: Proceedings of the First Annual International Topical Meeting, April 8-12, 1990 (American Nuclear Society, La Grange Park, Illinois, 1990), pp. 153-162. 
5. Birdsell, K.H., L.F. Brown, A.E. Norris, G.A. Cederberg, B.J. Travis, and P.G. Stringer, "Modeling Tracer Diffusion in Fractured and Unfractured, Unsaturated, Porous Media," Journal of Contaminant Hydrology 3, (1988).

6. Elkins, N., "Prioritization of ESF Testing and Integration with Design and Construction," in High Level Waste Management: Proceedings of the Fourth Annual International Conference, Las Vegas, Nevada, April 26-30, 1993 (American Nuclear Society, La Grange Park, Illinois, 1993), pp. 521-523.

7. Dagan, G., V. Nguyen, and E. Springer, "Analysis of Solute Transport in an IntermediateScale Unsaturated Flow Experiment," High Level Radioactive Waste Management: Proceedings of the Second Annual International Conference, Las Vegas, Nevada, April 28-May 3, 1991 (American Nuclear Society, La Grange Park, Illinois, 1991), pp. 837844.

8. Erdal, B.R., R.S. Rundberg, W.R. Daniels, K. Wolfsberg, A.M. Friedman, S. Fried, and J. Hines, "Nuclide Migration Field Experiments in Tuff, G-Tunnel, Nevada Test Site," in Scientific Basis for Nuclear Waste Management 6, 207-216 (1982).

9. Erdal, B.R., K. Wolfsberg, J.K. Johnstone, K.L. Erickson, A.M. Friedman, S. Fried, and J. Hines, "Nuclide Migration Field Experiments--Program Plan," Los Alamos National Laboratory report LA-8487-PR (1981).

10. Fabryka-Martin, J.T., S.J. Wightman, W.J. Murphy, M.P. Wickham, M.W. Caffee, G.J. Nimz, J.R. Southon, and P. Sharma, "Distribution of Chlorine-36 in the Unsaturated Zone at Yucca Mountain: an Indicator of Fast Transport Paths," in Proceedings: Site Characterization and Model Validation Focus '93 (American Nuclear Society, La Grange Park, Illinois, 1993) pp. 58-68.

11. Greenwade, L.E., and G.A. Cederberg, "Preliminary Geochemical/Geophysical Model of Yucca Mountain," in Proceedings of the Materials Research Society Symposium 84, 703-712 (1987).

12. Kalia, H.N., "Acquisition of Test Data from the Exploratory Studies Facility for the Yucca Mountain Site Characterization," Symposium on Mine Mechanization and Automation June 7-10, 1993 at Lulea, Sweden (1993).

13. Kalia H.N., "Role of Underground Testing to Determine Suitability of Yucca Mountain as a Potential Repository Site," in High Level Radioactive Waste Management:

Proceedings of the First Annual International Topical Meeting, April 8-12, 1990 (American Nuclear Society, La Grange Park, Illinois, 1990), pp. 843-847.

14. Kalia, H.N., and N.Z. Elkins, "Characterization Testing Support Requirements for the Exploratory Shaft Facility at Yucca Mountain," International Conference on Shaft Drilling Technology, May 2-4, 9 (1990).

15. Kalia H.N., and W.A. Girdley, "Prototype Testing for the Yucca Mountain Project," in High Level Radioactive Waste Management: Proceedings of the First Annual International Topical Meeting April 8-12, 1990 (American Nuclear Society, La Grange Park, Illinois, 1990), pp. 843-847.

16. Kalia, H.N., and T.J. Merson, "Exploratory Shaft Facility: Its Role in the Characterization of the Yucca Mountain Site For a Potential Nuclear Waste Repository," International Symposium on Unique Underground Structures, June 12-15, (1990). 
17. Kalia, H.N., and J.M. Replogle, "Starter Tunnel at Yucca Mountain," in Institute of Shaft Drilling Techniques: Conference Proceedings of the April 13-21 Meeting, (1994).

18. Kelkar, S., and G.A. Zyvoloski, "Modeling of Coupled Heat-Mass-Stress Effects in Geologic Media," in High Level Radioactive Waste Management: Proceedings of the First Annual International Topical Meeting, April 8-12, 1990 (American Nuclear Society, La Grange, Illinois, 1990),pp. 951-920.

19. McWilliams, T.P., "Sensitivity Analysis of Geologic Computer Models; A Formal Procedure Based on Latin Hypercube Sampling," Mathematical Geology 9, $81-90$ (1987).

20. Nelson, D.C., T.J. Merson, P.L. McGuire, and W.L. Sibbitt, "Conceptual Design Report, Exploratory Shaft-Phase I. Nevada Nuclear Waste Storage Investigations," Los Alamos National Laboratory report LA-9179-MS (1982).

21. Norris, A.E., "The Use of Chlorine Isotope Measurements to Trace Water Movements at Yucca Mountain," in Proceedings of the Nuclear Waste Isolation in the Unsaturated Zone, Focus '89 Conference (American Nuclear Society, La Grange Park, Illinois, 1990), pp. 400-405.

22. Norris, A.E., H.W. Bentley, S. Cheng, P.W., Kubik, P. Sharma, and H.E. Gove, ${ }^{136} \mathrm{Cl}$ Studies of Water Movements Deep Within Unsaturated Tuffs," Nuclear Instruments and Methods in Physics Research B52, $455-460$ (1990).

23. Norris, A.E., K. Wolfsberg, S.K. Gifford, H.W. Bentley, and D. Elmore, "Infiltration at Yucca Mountain, Nevada, Traced by Cl-36," Nuclear Instruments \& Methods B29, pp. 376-379 (1987).

24. Norris, A.E., F.M. Byers, Jr., and T.J. Merson, "Fran Ridge Horizontal Coring Summary Report Hole UE-25h\#1, Yucca Mountain Area, Nye County, Nevada," Los Alamos National Laboratory report LA-10859-MS (1986).

25. Norris, A.E., K. Wolfsberg, and S.K. Gifford, "36Cl Measurements of the Unsaturated Zone Flux at Yucca Mountain," presented at International Topical Meeting on High Level Nuclear Waste Disposal: Pasco, Washington, September 24-26, 1985, H.C. Burkholder, Ed. (Battelle Press, Columbus, Ohio, 1986), pp. 381-388.

26. Norris, A.E., R.D. Aguilar, B.P. Bayhurst, D.L. Bish, M.R. Cisneros, W.R. Daniels, J. Duffy, R.D. Golding, S.L. Jensen, S.D. Knight, F.O. Lawrence, S. Maestas, J. Mitchell, P.Q. Oliver, N.A. Raybold, R.S. Rundberg, G.M. Thompson, N. Treher, B.J. Travis, G.R. Walter, R.G. Warren, and K. Wolfsberg, "Geochemistry Studies Pertaining to the G-Tunnel Radionuclide Migration Field Experiment," Los Alamos National Laboratory report LA-9332-MS (1982). 
27. Ogard, A.E., J.L. Thompson, R.S. Rundberg, K.Wolfsberg, P.W. Kubik, D. Elmore and H.W. Bentley, "Migration of Chlorine-36 and Tritium from an Underground Nuclear Test," Radiochimica Acta 44/45, 213-217 (1988).

28. Oliver, R. and D., and H.N. Kalia, "Status Report on ESF-Related Prototype Testing," Los Alamos National Laboratory report LA-12411-SR (1993).

29. Polzer, W.L., H.R. Fuentes, E.P. Springer, and J.W. Nyhan, "Modeling Study of Solute Transport in the Unsaturated Zone: Information and Data Sets," Los Alamos National Laboratory report LA-10730-MS (1986).

30. Ray, J.M., and J.C. Newsom, "The Yucca Mountain Project Prototype Air-Coring Test U12g Tunnel, Nevada Test Site," Los Alamos National Laboratory report LA-11844-MS (1994).

31. Skaggs, B.J., L.W. Ortiz, D.J. Burton, B.L. Isom, and E.A. Vigil, "Evaluation of DustRelated Health Hazards Associated with Air Coring at G-Tunnel, Nevada Test Site," Los Alamos National Laboratory report LA-11594-MS (1991).

32. Travis, B.J., "TRACR3D: A Model of Flow and Transport in Porous/Fractured Media," Los Alamos National Laboratory report LA-9667-MS (1984).

33. Travis, B.J., and K.H. Birdsell, "TRACR3D: A Model of Flow and Transport in Porous Media, Model Description and User's Manual," Los Alamos National Laboratory report LA-11798-M (1991).

34. Travis, B.J., and T.L. Cook, "Simulation of Flow and Transport in Partially Saturated, Fractured Tuff," in Proceedings of the Materials Research Society Annual Meeting, Boston, Massachusetts, November 13-18, 1983, (Materials Research Society, Pittsburgh, Pennsylvania, 1983), p. 17.

35. Van Eeckhout, E., "Controlled Blasting and Its Implications for the NNWSI Project Exploratory Shaft," Los Alamos National Laboratory report LA-11097-MS (1987).

36. Zyvoloski, G.A., "Simulation of Heat Transfer in the Unsaturated Zone," in High Level Radioactive Waste Management: Proceedings of the First Annual International Topical Meeting, April 8-12, 1990 (American Nuclear Society, La Grange Park, Illinois, 1990), pp. 611-617.

37. Zyvoloski, G.A., Z.V. Dash, and S.M. Kelkar, "FEHMN 1.0: Finite Element Heat and Mass Transfer Code," Los Alamos National Laboratory report LA-12062-MS (1992). 


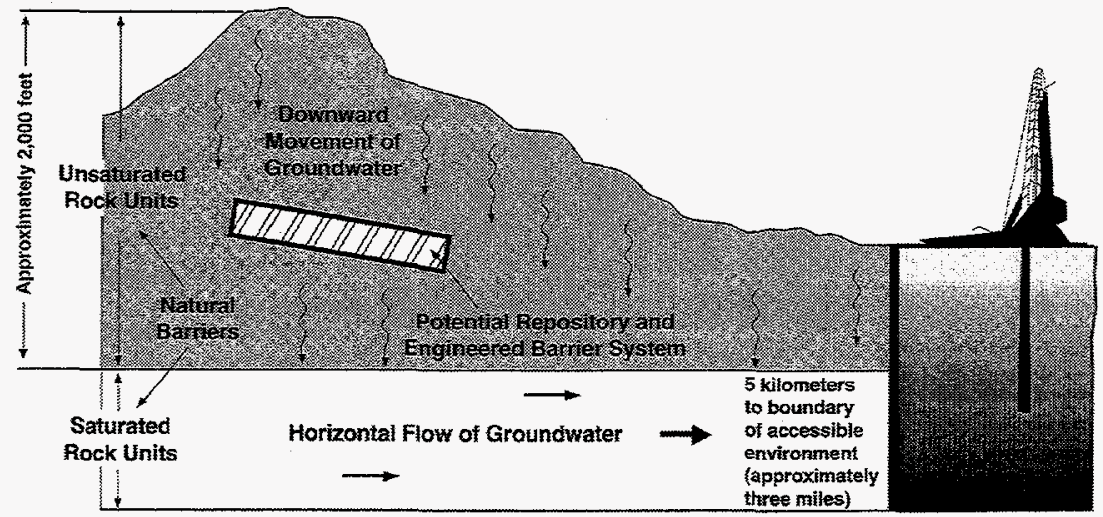

Schematic of the potential repository site in unsaturated rock at Yucca Mountain

\section{Summary/Status Reports}

1. Bryant, E.A., and D.T. Vaniman, Compilers, "Research and Development Related to the Nevada Nuclear Waste Storage Investigations; July 1 - September 30, 1983," Los Alamos National Laboratory report LA-10006-PR (1984).

2. Canepa, J.A., I.R. Triay, P.S. Rogers, M.E. Hawley and G.A. Zyvoloski, "The Yucca Mountain Site Characterization Project: Site-Specific Research and Development on the Chemistry and Migration of Actinides," in Chemistry and Migration Behavior of Actinides and Fission Products in the Geosphere: Proceedings of the Fourth International Conference, Charleston, South Carolina, USA, December 12-17, 1993, pp. 813-820 (1994).

3. Canepa, J.A., and R.J. Herbst, "Geochemistry of the Yucca Mountain Site: An Overview of the Approach to Characterization," in Proceedings of Waste Management ' 89 525-530 (1989).

4. Crowe, B.M., Compiler, "Research and Development Related to the Nevada Nuclear Waste Storage Investigations, January 1 - March 31, 1984," Los Alamos National Laboratory report LA-10154-PR (1985).

5. Crowe, B.M., Editor, "Research and Development Related to the Nevada Nuclear Waste Storage, Investigations, October 1 - December 31, 1979," Los Alamos Scientific Laboratory report LA-8309-PR (1980). 
6. Crowe, B.M., Compiler, "Research and Development Related to the Nevada Nuclear Waste Storage Investigations, January 1 - March 31, 1979," Los Alamos Scientific Laboratory report LA-7900-PR (1979).

7. Crowe, B.M., Editor, "Research and Development Related to the Nevada Nuclear Waste Storage Investigations, July 1 - September 30, 1979," Los Alamos Scientific Laboratory report LA-8152-PR (1979).

8. Crowe, B.M., and K. Wolfsberg, Editors, "Research and Development Related to the Nevada Nuclear Waste Storage Investigations, January 1 - March 31, 1979," Los Alamos Scientific Laboratory report LA-8419-PR (1980).

9. Daniels, W.R., Editor, "Summary Report on the Geochemistry of Yucca Mountain and Environs," Los Alamos National Laboratory report LA-9328-MS (1982).

10. Daniels, W.R., B.R. Erdal, and D.T. Vaniman, Compilers, "Research and Development Related to the Nevada Nuclear Waste Storage Investigations, July 1 - September 30, 1982," Los Alamos National Laboratory report LA-9577-PR (1983).

11. Daniels, W.R., K. Wolfsberg, D.T. Vaniman, and B.R. Erdal, Editors, "Research and Development Related to the Nevada Nuclear Waste Storage Investigations, January 1 March 31, 1982," Los Alamos National Laboratory report LA-9327-PR (1982).

12. Erdal, B.R., "Geology of Waste Management," Los Alamos National Laboratory annual report LALP 82-30 (1982).

13. Erdal, B.R., W.R. Daniels, D.T. Vaniman, and K. Wolfsberg, Editors, "Research and Development Related to the Nevada Nuclear Waste Storage Investigations, July 1 September 30, 1981," Los Alamos National Laboratory report LA-9095-PR (1981).

14. Erdal, B.R., W.R. Daniels, D.T. Vaniman, and K. Wolfsberg, Editors, "Research and Development Related to the Nevada Nuclear Waste Storage Investigations, April 1 June 30, 1981," Los Alamos National Laboratory report LA-8959-PR (1981).

15. Erdal, B.R., and K. Wolfsberg, Editors, "Research and Development Related to the Nevada Nuclear Waste Storage Investigations, January 1 - March 31, 1981," Los Alamos National Laboratory report LA-8847-PR (1981).

16. Herbst, R.J., and J.A. Canepa, "Assessment of Radionuclide Retardation," Radioactive Waste Management and the Nuclear Fuel Cycle 13, 77-92 (1989).

17. Kalia, H., "Control of Tracers, Fluids, and Materials for the Yucca Mountain Site Characterization Project," in High Level Waste Management: Proceedings of the Fourth Annual International Conference, Las Vegas, Nevada, April 26-30, 1993 (American Nuclear Society, La Grange Park, Illinois, 1993), pp. 524-526.

18. Ogard, A.E., "The Nevada Nuclear Waste Storage Investigations," Los Alamos National Laboratory report LA-10130-PR, pp. 109-110 (1984). 
19. Ogard, A.E., and D.T. Vaniman, Compilers, "Research and Development Related to the Nevada Nuclear Waste Storage Investigations, July 1 - September 30, 1984," Los Alamos National Laboratory report LA-10299-PR (1985).

20. Ogard, A.E., K. Wolfsberg, and D.T. Vaniman, Compilers, "Research and Development Related to the Nevada Nuclear Waste Storage Investigations; April 1 - June 30, 1983," Los Alamos National Laboratory report LA-9846-PR (1983).

21. Ogard, A.E., W.R. Daniels, and D.T. Vaniman, Compilers, "Research and Development Related to the Nevada Nuclear Waste Storage Investigations, October 1 - December 31, 1982," Los Alamos National Laboratory report LA-9666-PR (1983).

22. Purson, J.D., "Evaluation of Geochemical Properties Used in Area-to-Location Screening for a Nuclear Waste Repository Site at the Nevada Test Site," Los Alamos National Laboratory report LA-9510-MS (1983).

23. Simmons, A.M., and J.A. Canepa, "Recent Developments in the Integrated Approach Toward Characterization of Radionuclide Transport, Yucca Mountain, Nevada," in Waste Management '92 1, (Arizona Board of Regents, Tucson, Arizona, 1992), pp. 947-951.

24. Thomas, K.W., Compiler, "Research and Development Related to the Nevada Nuclear Waste Storage Investigations, October 1 - December 31, 1984," Los Alamos National Laboratory report LA-1 1443-PR (1988).

25. West, K.A., "Nevada Nuclear Waste Storage Investigation Exploratory Shaft Facility Fluids and Materials Evaluation," Los Alamos National Laboratory report LA-11398-MS (1988).

26. Wolfsberg, K., Editor, "Research and Development Related to the Nevada Nuclear Waste Storage Investigations, April 1 - June 31, 1979," Los Alamos Scientific Laboratory report LA-7974-PR (1979).

27. Wolfsberg, K., Compiler, "Research and Development Related to the NTS Terminal Waste Storage Project, October 1 - December 31, 1978," Los Alamos Scientific Laboratory report LA-7647-PR (1979).

28. Wolfsberg, K., and B.R. Erdal, Editors, "Research and Development Related to the Nevada Nuclear Waste Storage Investigations, October 1 - December 31, 1980," Los Alamos National Laboratory report LA-8739-PR (1981).

29. Wolfsberg, K., and D.T. Vaniman, Compilers, "Research and Development Related to the Nevada Nuclear Waste Storage Investigations; October - December 31, 1983," Los Alamos National Laboratory report LA-10032-PR (1984).

30. Wolfsberg, K., A.E. Ogard, and D.T. Vaniman, Compilers, "Research and Development Related to the Nevada Nuclear Waste Storage Investigations; January 1 - March 31, 1983," Los Alamos National Laboratory report LA-9793-PR (1983).

31. Wolfsberg, K., W.R. Daniels, D.T. Vaniman, and B.R. Erdal, Editors, "Research and Development Related to the Nevada Nuclear Waste Storage Investigations, October 1 December 31, 1982," Los Alamos National Laboratory report LA-9225-PR (1982).

32. Wolfsberg, K., W.R. Daniels, B.R. Erdal, and D.T. Vaniman, Compilers, "Research and Development Related to the Nevada Nuclear Waste Storage Investigations, April 1 - June 
30, 1982," Los Alamos National Laboratory report LA-9484-PR (1982).

33. Wolfsberg, K., B.R. Erdal, and B.M. Crowe, Editors, "Research and Development Related to the Nevada Nuclear Waste Storage Investigations, July 1 - September 30, 1980," Los Alamos Scientific Laboratory report LA-8612-PR (1981).

34. Wolfsberg, K., B.R. Erdal, and J.R. Smyth, Editors, "Research and Development Related to the Nevada Nuclear Waste Storage Investigations, April 1 - June 30, 1985," Los Alamos Scientific Laboratory report LA-8471-PR (1980). 


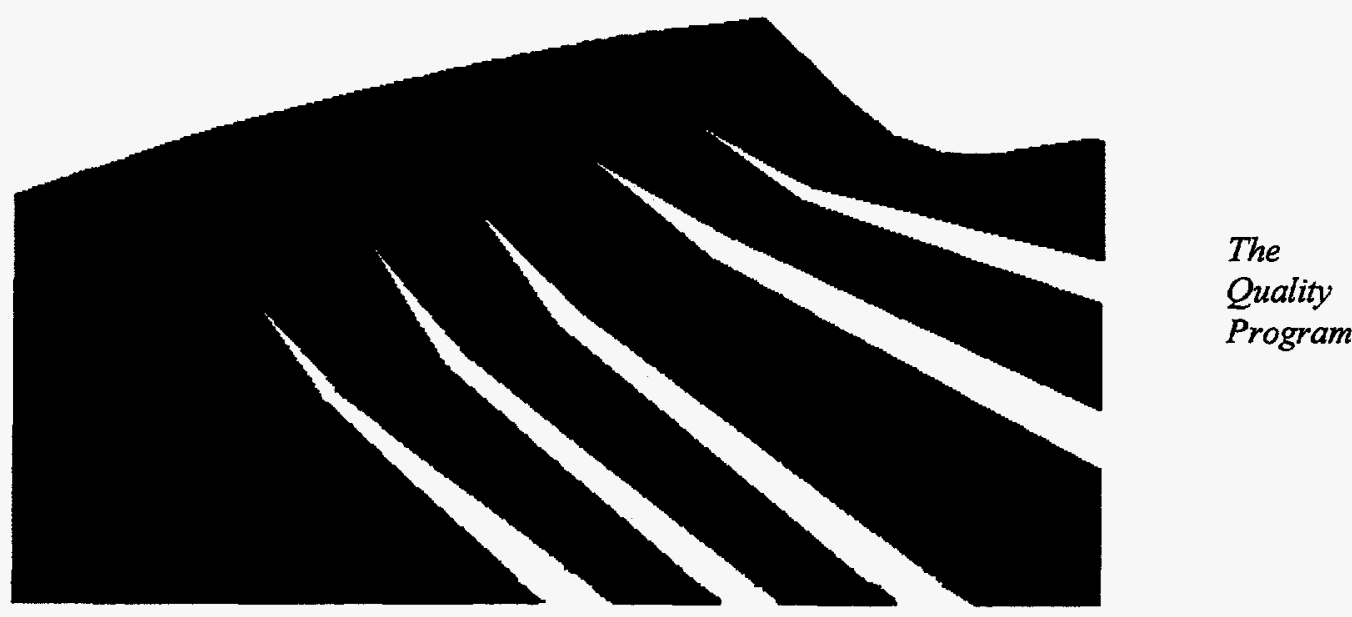

\section{Quality Assurance}

1. Bolivar, S.L., "Los Alamos National Laboratory Yucca Mountain Site Characterization Project 1992 Quality Program Status Report," Los Alamos National Laboratory report LA-12703-SR (1994).

2. Bolivar, S.L, and J.L. Day, "The Transition to a Revised Quality Assurance Standard, the Los Alamos Experience," Proceedings of the Nineteenth Annual American Society for Quality Control (ASQC) National Energy \& Environmental Quality Division Conference, September 18-21, (1994).

3. Bolivar, S.L., "The Quality Assurance Liaison: Combined Technical and Quality Assurance Support," in The 17th Annual 1993 Rocky Mountain Quality Conference Denver, Colorado, June 6-8, 1993, pp. 97-104 (1993).

4. Bolivar, S.L., "Los Alamos National Laboratory, Yucca Mountain Site Characterization Project 1991 Quality Program Status Report," Los Alamos National Laboratory report LA-12344-MS (1992).

5. Bolivar, S.L., and J.L. Day, "The Role of the Los Alamos National Laboratory's Yucca Mountain Site Characterization Project," in Proceedings of the Nineteenth Annual American Society for Quality Control (ASQC) National Energy \& Environmental Quality Division Conference, Lake Buena Vista, Florida, September 20-23, (1992). 
6. Bolivar, S.L, and J.L. Day, "Say the Right Thing," 17 minute video tape for Yucca Mountain Project describing auditing techniques, EES-13 document (1991).

7. Day, J.L., P.L. Gillespie, and S.L. Bolivar, "The Quality Council in the Scientific Arena," 48th Annual American Quality Congress (AQC) Proceedings Las Vegas, Nevada, May 24-26, 87-92 (1994). 